\title{
各種フライアッシュの共通試験報告
}

\begin{tabular}{|c|c|c|c|c|c|}
\hline 委員 & 長 工博 & 国 & 分 & 正 & 扸* \\
\hline 幹 & 事 & 河 & 原 & 友 & 純** \\
\hline 幹 & 事 & 太 & 斉 & 宗 & 一类** \\
\hline
\end{tabular}

\section{COLLECTIVE TESTS OF VARIOUS FLY ASH}

\author{
Reportde by Japan Society of Civil Engineers Subcommittee on Fly Ash**** \\ Chairman :Dr. Eng., Masatane Kokubu, C.E. Member, \\ Secretaries: Tomozumi Kawahara, C.E. Member, \\ and Sôichi Dazai, C.E. Member
}

\section{Synopsis :}

A broad investigation undertaken by the Subcommittee on Fly Ash of quality and uniformity of fly ash from the major producers in Japan is discussed in this paper. Fly ash from thirteen plants of nine firms were sent in three shipments each to thirteen different laboratories where identical tests were conducted. Uniformity of samples taken daily at eleven plants for approximately one month running on two occasions were also tested. It is concluded that (1) thirty-two of a total of thirty-three varieties of fly ash were acceptable in quality under Japanese Industrial Standard (JIS) designations, results of tests on concrete made with these fly ashes being good, although there was considerable dissimilarity in quality between each other, while at few plants there was a great difference according to the time of day that samples were obtained and (2) that the deviation in quality of fly ash between periods of high and low water fell within the range specified in JIS.

要 旨 本文は国内の主要フラィアッシュの品質ならびに品質の均一性を, フライアッシュ小委員会 で広く調査した結果を論じたものである。すなわち 9 会社の 13 工場で生産されたフライアッシュを， 13 の試験所へ 3 回にわたり送付して共通試験を行うとともに, 11 工場に拉いて 2 回にわたり約 1 力月間 連続して試料を採取し均一性を調査した結果を述べ，(1) 合計 33 種のろち 32 種のフライアッシュが 日本工業規格の品質の規定に合格し，これらをコンクリートに用いて試験した結果も良好であつたが， 品質を相互に比較すればいちじるしい差があり，少数の工場では採取時期の相違によつて大差が認めら れたこと，(2) フライアッシュの品質の変動は混水期にも豊水期にも日本工業規格の品質の均一性の規 定の範囲内のものであつたこと, 等を結論したものである。

目次

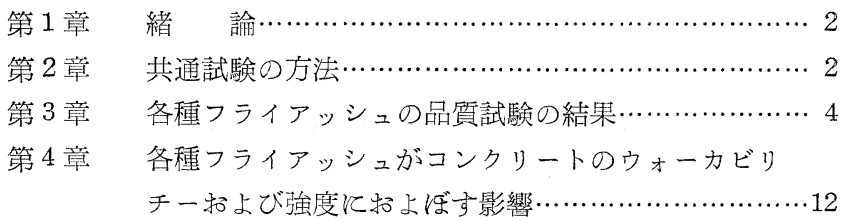

第 5 章 各種フライアッシュの品質の均一性に関する調査 $\cdots \cdots 21$

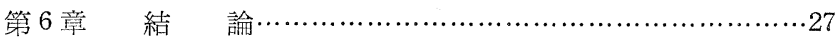

付 録 フライアッシュに関する参考文献………………...28

* 正 員 東京大学教授, 工学部土木工学教室

** 正 員電力中央研究所技術研究所, 第二部コンクリート研究室

*** 正 員 電源開発 $\mathrm{KK}$, 土木部設計課

****Subcommittee of Committee on Concrete and Reinforced Concrete. 


\section{第 1 章 緒}

フライアッシュをコンクリートの混和材料として用いるための研究は, わが国でも数年前からさかんに行わ れ, 現在まで約 200 編の論文も発表されている。良質のフライアッシュの利点, すなわち, (1) コンクリートの ウォーカビリチーを改善すること，(2) 適当に使用すれば長期材令に括けるコンクリートの強度掠よび水密性を 改善すること，(3) マッシブなコンクリートでは硬化による発熱を緩和しひびわれの括とれを少なくすること， （4）安価であること，等が実証され，また，これを用いる場合の諸注意事項が明らかにされてくるに従い，火力

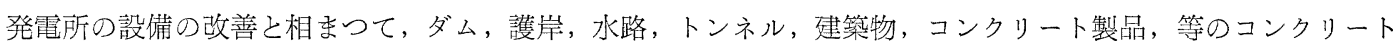
にフライアッシュがさかんに利用されるようになり，今日で注年間使用量も約 $300,000 \mathrm{t}$ 亿達している。これは 新資源の活用ということであつて，誠に喜ばしい。

しかし，このようと各処で使用され始めると，これらのフライアッシュの品質が良好であるかどうか，また， 均等質なるのであるかどうか，を広く調查することが必要となる。な招フライアッシュの使用方法についての一 層の研究が必要になることは論をまたない。これらの点についての調査研究を行うため, 土木学会コンクリート 常置委員会にフライアッシュ小委員会を設け，昭和 32 年 6 月以来研究をつづけている。

小委員会で試験したフライアッシュは, 関電フライアッシュ KK (関西電力), 東電フライアッシュ工業 $\mathrm{KK}$, 中電興業 $\mathrm{KK}$ (中部電力), 九電フライアッシュ KK, 中電産業 KK (中国電力), 東北フライアッシュ KK, 常 磐共同火力 $\mathrm{KK}$, 旭ガラス $\mathrm{KK}$, 宇部興産 $\mathrm{KK}$, 等 9 会社の 13 工場（火力発電所）で生産したもので, 全国に 使用されているフライアッシュがほとんど全部網羅されている。な特，各工場から直送されたるのばかりでな く, 電源開発 $\mathrm{KK}$, 中部電力 $\mathrm{KK}$, 関西電力 $\mathrm{KK}$, 中国電力 $\mathrm{KK}$, 九州電力 $\mathrm{KK}$, の 6 工事現場嗬している フライアッシュについても試験した。この共通試験に参加した試験所は, 東京大学工学部, 建設省土木研究所, 国鉄鉄道技術研究所, 電力中央研究所, 電源開発 $\mathrm{KK}$, 日本セメント $\mathrm{KK}$, 小野田セメント $\mathrm{KK}$, 日本セメント 技術協会, 東北電力 $\mathrm{KK}$, 中電興業 $\mathrm{KK}$, 関電フライアッシュ $\mathrm{KK}$, 中電産業 $\mathrm{KK}$ ，九電フライアッシュ $\mathrm{KK}$, 等 の13 亿招よんでいる。また, フライアッシュの品質の均一性は最も大切な性質であるので, 11 工場に括いて, 豊水期招よび渴水期飞とれぞれ約 1 カ月にわたつて試料を採取し，品質の変動を調查した。

工業技術院のフライアッシュ専門委員会では, 昭和 31 年から審議を重称, 昭和 33 年にフライアッシュの日 本工業規格 (JIS A 6201) を制定したが, この専門委員会に資料として調查研究の一部を提出した。この JIS の諸規程, 特に試験方法の信頼度について共通試験で再検討したのである。

調査研究の経過は 2 回にわたつて土木学会年次学術講演会*で発表した。本報告は, フライアッシュ小委員会 の各委員が行つた共通の調査研究を取りまとめたものでめつて, 全国主要フライアッシュの品質ならびに品質の 均一性を明らかにしたものである。な㧍フライアッシュの研究者拉よび使用者の便に供するため巻末に既往の主 要な参考文献を添付した。

この共通の調查研究のほか飞, フライアッシュがコンクリートの乾燥収縮, 耐久性, 等飞挌よぼす影響, 招上 び養生中の温度ならびに湿度がフライアッシュを用いたコンクリートの強度に㧍よぼす影響, 等についても研究 したが，これらは共通して行つたものではないので改めて各委員から報告する予定である。な招今後は，フライ アッシュを用いたコンクリート中に招けるかぶりの薄い鉄筋の腐食についてる研究を進めたいと考光ている。

調查研究に当り懇切な御指導を賜わつたコンクリート常置委員会委員長 吉田徳次郎先生, また, 終始熱心沉 御協力いただいた委員各位ならびそ工事現場の担当者の方々に謹んで厚く御礼申上げる。

\section{第 2 章 共通試験 の方法}

\section{1. フライアッシュ}

共通試験は 3 回にわたつて行い，陚験に用いたフライアッシュは，それぞれの工場に扔ける代表的資料が得ら れるよろ, 特に入念棌取した。また, 採取した試料を 13 の試験所（A,B,C,D,E,F, G,H,I,J,K,L,M と記した） へ分配する場合にも，各試験所の試料が均等であるよう特飞注意を払つた。

第 1 回試験に用いたフライアッシュは炤和 32 年 7 月に各工場から採取したものであり, 第 2 回試験飞用いた ものは昭和 32 年 12 月に採取したものであつて, 工場は 7 工場であり，これらの試料をそれぞれ，1,2,3,4,5, 6,7 と名付けた。この両回の試験は, それぞれ，豊水期招よび渴水期に括けるフライアッシュの品質を確かめる 
ためのるのである。

第 3 回試験飞用いたフライアッシュは，昭和 33 年 10 月に 13 工場から採取したもの(これらの試料を 101 〜113 と名付けた）と6工事現場に到着していたるの（201〜206 と名付けた）との19 武料である。すなわちこ の陚験においては, 工事現場に入荷したフライアッシュと工場で採取したものとの間の品質の相違をも確かめた のであつて，工事現場への連絡はフライアッシュの使用者側の委員が担当した。

上記のようにフライアッシュの試料はすべて番号で整理したのであつて，番号と工場名あるい侩社名との関 係柇委員中の1名だけが知り，他の委員怙よび試験担当者に知らせていない。すなわち，各工場招よび工事現 場から試料の全量をその1名の委員へ送り, この委員がそれぞれのフライアッシュを整理して番号を付け, ブり キ年滵封して各武験所へ分配したのである。これは, 試験の公正を期するための考慮である。

\section{2. セメントおよび骨材}

第 1 回挌よび第 2 回試験には, 日本セメントKK 西多摩工場製普通ポルトランド セメントを用い, 第 3 回試 験とは小野田セメントKK藤原工場製普通ポルトランドセメントを用いた。セメントの試験 結果は表一1のよ ろであつた。

化学成分 $(\%)$ および諸比率

表一1 セメントの試 験 成 績

\begin{tabular}{|c|c|c|c|c|c|c|c|c|c|c|c|c|c|}
\hline 強熱減量 & 不溶残分 & シリカ & アルミナ & 酸化鉄 & 酸 法ルンム 化 & 㕕マゲネンア & 無水硫酸 & 合 計 & H. M & A. I & S. $M$ & I. $\mathrm{M}$ & L.S.D \\
\hline \multicolumn{14}{|c|}{ 第 1 回試験 } \\
\hline 0.84 & 0.32 & 22.90 & 5.60 & 3.04 & 64.04 & 1.30 & 1.53 & 99.57 & 2.00 & 4.09 & 2.65 & 1.84 & 0.846 \\
\hline \multicolumn{14}{|c|}{ 第 2 回試験 日本セメントKK西多摩工場製, 普通ポルトランド セメント } \\
\hline 0.82 & 0.42 & 22.62 & 5.29 & 2.89 & 64.34 & 1.45 & 1.61 & 99.44 & 2.05 & 4.28 & 2.77 & 1.83 & 0.865 \\
\hline \multicolumn{14}{|c|}{ 第 3 回試験 小野田セント KK藤原工場製, 普通ホホルトランド セメント } \\
\hline 0.65 & 0.26 & 22.14 & 4.84 & 3.18 & 65.32 & 1.48 & 1.48 & 99.35 & 2.13 & 4.57 & 2.76 & 1.52 & 0.920 \\
\hline
\end{tabular}

物 理 的 性 質

\begin{tabular}{|c|c|c|c|c|c|c|c|c|c|c|c|c|c|c|c|c|c|}
\hline \multirow{3}{*}{ 比重 } & \multicolumn{2}{|c|}{ 粉 末 度 } & \multicolumn{3}{|c|}{ 凝 } & \multicolumn{2}{|c|}{ 結 } & \multirow{3}{*}{$\begin{array}{l}\text { 安定性 } \\
\text { パット }\end{array}$} & \multirow{3}{*}{$\begin{array}{l}\text { フロー } \\
(\mathrm{mm})\end{array}$} & \multicolumn{4}{|c|}{ 強 } & \multicolumn{4}{|c|}{$\left(\mathrm{kg} / \mathrm{cm}^{2}\right)$} \\
\hline & \multirow{2}{*}{$\left|\begin{array}{l}\text { プレーン } \\
\text { 傐 } \\
\left(\mathrm{cm}^{2} / \mathrm{g}\right)\end{array}\right|$} & \multirow{2}{*}{$\begin{array}{c}88 \mu \\
\text { 残分 } \\
(\%)\end{array}$} & \multirow{2}{*}{$\begin{array}{c}\text { 温 度 } \\
\left({ }^{\circ} \mathrm{C}\right)\end{array}$} & \multirow{2}{*}{$\begin{array}{c}\text { 湿 度 } \\
(\%)\end{array}$} & \multirow{2}{*}{$\begin{array}{l}\text { 水 量 } \\
(\%)\end{array}$} & \multirow{2}{*}{$\left|\begin{array}{cc}\mid \\
\text { 始 } & \text { 発 } \\
\text { (時一分) }\end{array}\right|$} & \multirow{2}{*}{$\begin{array}{c}\text { 終 } \\
\text { 結 } \\
(\text { 時一分) }\end{array}$} & & & \multicolumn{2}{|r|}{ 曲 } & \multicolumn{2}{|c|}{$け ゙$} & \multicolumn{2}{|c|}{ 圧 } & \multicolumn{2}{|c|}{ 縮 } \\
\hline & & & & & & & & & & 3 日 & 7 日 & 28 日 & 91日 & 3 日 & 7 日 & 28 日 & 91日 \\
\hline \multicolumn{18}{|c|}{ 第 1 回詓験 } \\
\hline 3.15 & 3,050 & 3.1 & 21.1 & 92 & 26.0 & $1-59$ & $3-59$ & 良 & 226 & 28.5 & 42.6 & 64.7 & 70.6 & 110 & 209 & 406 & 485 \\
\hline \multicolumn{18}{|c|}{ 第 2 回試験 日本セメント KK 西多摩工場製, 普通ポルトランド セメント } \\
\hline 3.15 & 3,010 & 3.1 & 20.7 & 91 & 26.0 & $2-33$ & $3-48$ & 良 & 227 & 40.3 & 43.4 & 64.8 & 71.5 & 116 & 202 & 412 & 482 \\
\hline \multicolumn{18}{|c|}{ 第 3 回試験 小野田セメント KK 藤原工場製, 普通ポルトランド セメント } \\
\hline 3.16 & 3,220 & 1.0 & 20.0 & 85 & 25.3 & $3-06$ & $4-17$ & 良 & 247 & 28.6 & 43.9 & 73.7 & 74.7 & 111 & 204 & 393 & 483 \\
\hline
\end{tabular}

これらのセメントは, それぞれ, 工場から各試験所へ直送したものであつて, 各試験所はセメントが到着した のちただちと試験を開始した。

コンクリートによる共通試験には, 各試験所で常時使用している細骨材括よび粗骨材を使用した。粗骨材の最 大寸法を $25 \mathrm{~mm}$ とした经かは特別に制限しなかつたが，いずれの骨材も土木学会コンクリート標準示方書の諸 規定に合するものである。

\section{3. フライアッシュの品質試験方法}

フライアッシュの品質試験は JIS A 6201*〜1958 そよつて行つた。粉末度試験に用いた標準網ふるい $44 \mu$ は, 㛜重に検査して入手した金網を用いてある製作所で作り，これを各試験所飞配布したすのである。

一部の試験所に扮いては, 活性炭素の含有量を推定するため, メチレンブルー溶液にフライアッシュを加えて 溶液中のメチレンブルーが吸着される程度を試験した。この試験は吉越盛次氏の提案**に準じて行つたものであ つて, 例党ば試験管に入れた一定濃度***のメチレンブルー溶液 $25 \mathrm{cc}$ にフライアッシュ $1 \mathrm{~g}$ を加えて十分浱 り, この懸濁液をろ過してろ過後の溶液に抢けるメチレンブルーの濃度を比色方法によつて測定し, フライア ッシュ $1 \mathrm{~g}$ に吸着されるメチレンブルーの量 $(\mathrm{mg} / \mathrm{g})$ を定めたのである。溶液をろ過するとろ紙にもメチレン

* 日本工業規格フライアッシュ **フライアッシュの参考文献 参照

*** 濃度を $35 \sim 40 \mathrm{mg} / l$ として試験した場合が多かつた。 
ブルーが吸着されるが，吸着される程度はろ紙によつていちじるしく相違し，同一商標のろ紙でも相違すること がある。それで，同種のろ紙を用いあらかじめこれにメチレンブルーを十分に吸着させてから溶液のろ過を行 ろ等，ろ紙の招よぼす影響をできるだけ少なくするようと注意してろ過した。

\section{4. コンクリートによる共通試験方法}

第 2 回怙よび第 3 回の試験に扔いては, フライアッシュがコンクリートのウォーカビリチー蛒よび強度に招よ ぽす影響についての共通試験を行つたのであつて, 表一2 亿示す項目を共通とした。すなわち, 単位セメント量 $300 \mathrm{~kg}$ のコンクリートと同じウォーカビリチーを持つコンクリートをフライアッシュを用いて造り，単位水量 の比を求めるとともに，コンクリートを $21^{\circ} \mathrm{C}$ の水中で養生したのち試験して压縮強度ならびに引張強度の比を 求めて比較したのであつて, 単位セメント フライアッシュ量 $(C+F)$ を $300 \mathrm{~kg}$ フライアッシュによるセメン トの招き換え率 $(F / C+F)$ を $25 \%$ とした。スランプの值恪試験所の任意としたため, $4.5 \mathrm{~cm}$ の所も $8 \mathrm{~cm} の$ 所も恋つたが，試験の目的は十分飞達せられた。

第 3 回試験は，ビンゾールを用いて造つた空気量 4〜5\%の AE コンクリートについてこれを行つた。2.に 述べたごとく，骨材は各試験所が所有するるのを用いたために，所望の空気量を得るに必要な単位 AE 剂量は試 験亦によつて相当に相違した（表一7参照）。

圧縮強度試験の供試体は直径 $10 \mathrm{~cm}$, 高さ $20 \mathrm{~cm}$ のシリンダーとし, 引張強度試験の供試体は直径 $15 \mathrm{~cm}$, 高さ $15 〜 20 \mathrm{~cm}$ のシリンダーとした。

表一2 コンクリート試験における共通項目

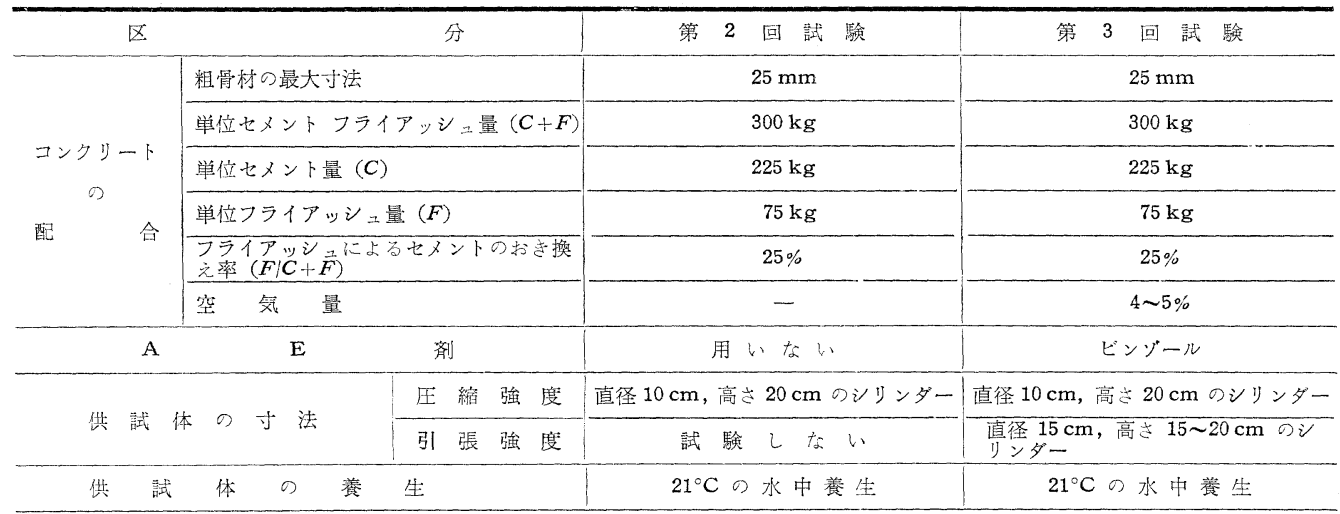

\section{第 3 章＼cjkstart各種フライアッシュの品質試験の結果}

\section{1. 第 1 回および第 2 回の品質試験結果}

第 1 回の品質試験の結果は表一3 亿示すとおりであり，第 2 回の結果は表一 4 亿示すとおりであつて，化学成 分, 比重, 粉末度拉よび単位水量比飞関しては，7 種のフライアッシュ全部が JIS の規定に合格している。圧 縮強度比も 11 試験所 (A,B,C,D,E,F,G,H,I,J,K) の全平均飞招いては 1〜6のフライアッシュはいずれも合格 し, ごく少数の試験所だけで渴水期（昭和 32 年 12 月）飞採取した 6 抢よび 1 のフライアッシュが不合格とな つている。しかし，7 のフライアッシュは渴水期に採取したものは不合格であり，豊水期（昭和 32 年 7 月）に 採取したるのも相当数の試験所で不合格となつている。

7 種のフライアッシュの品質を比較すると相当な差が認められ，44 ふふるいによる粉末度は 2〜21\%, 単位水 量比は 92〜98\%，91 日圧縮強度比は 107\%〜 78\%の範囲に相違している。

また，同種のフライアッシュに物ける豊水期と渴水期との試駼結果を比較すると，フライアッシュの1,3,5 招

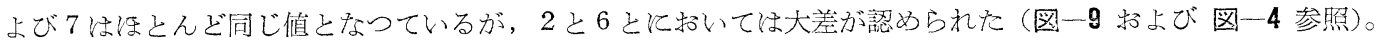

表一8，9，10 は第 1 回の試験に打ける各試験所の間の試験值の変動を総括したものであつて, 試験值の平均 值 $(\bar{X})$, 標準偏差 $(\sigma)$, 変動係数 $(V)$, 最大值 $\left(X_{\max }\right)$, 最小值 $\left(X_{\min }\right)$, 最大值と最小值との差 $(R)$ 等が示 されている。表一11 は各フライアッシュの品質の相違を総括したものである。表一8，9，10 から次のことが認 められる。

（1）単位水量比の試験值の標準偏差は非常に小さく, フライアッシュ 7 種のうらの 6 種では $1.5 \%$ 以下に過 ぎないのであつて，との試験方法が栖準試験方法として適当なるのであることが示されている。 
表一3 フライアッシュの品質試験成績表（第 1 回試験）

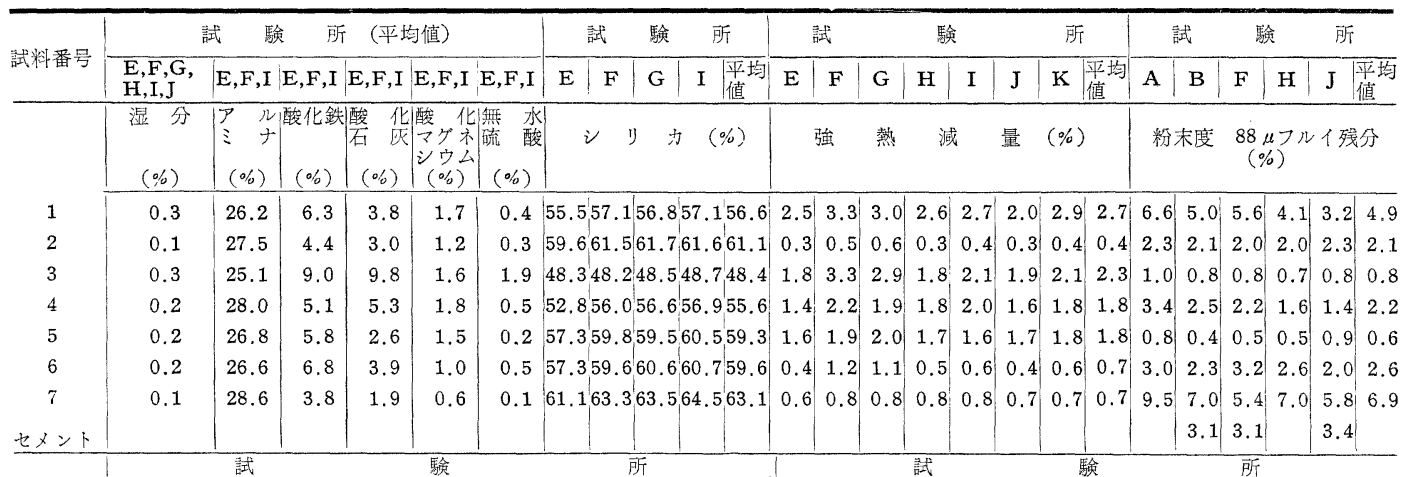

\begin{tabular}{c|c|c|c|c|c|c|c|c|c|c|c|c|c|c|c|c|c|c|c|c|c|c|c|}
$\mathrm{A}$ & $\mathrm{B}$ & $\mathrm{C}$ & $\mathrm{D}$ & $\mathrm{E}$ & $\mathrm{F}$ & $\mathrm{G}$ & $\mathrm{H}$ & $\mathrm{I}$ & $\mathrm{J}$ & $\mathrm{K}$ & 平域 & $\mathrm{A}$ & $\mathrm{B}$ & $\mathrm{C}$ & $\mathrm{D}$ & $\mathrm{E}$ & $\mathrm{F}$ & $\mathrm{G}$ & $\mathrm{H}$ & $\mathrm{I}$ & $\mathrm{J}$ & $\mathrm{K}$ & 平均值 \\
\hline
\end{tabular}

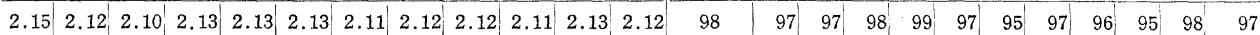

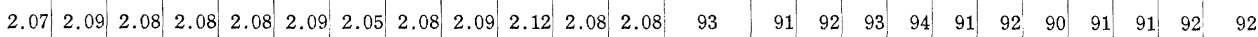

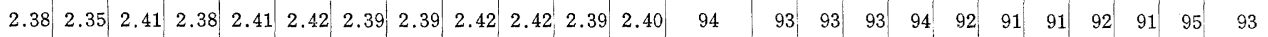

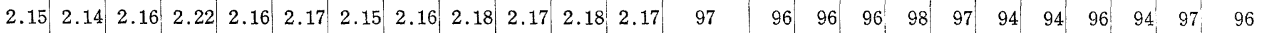

\begin{tabular}{l|l|l|l|l|l|l|l|l|l|l|l|l|l|l|l|l|l|l|l|l|l|l|l|}
2.13 & 2.12 & 2.12 & 2.12 & 2.13 & 2.13 & 2.12 & 2.12 & 2.13 & 2.13 & 2.13 & 2.13 & 97 & 93 & 94 & 94 & 96 & 95 & 93 & 95 & 94 & 93 & 95 & 94
\end{tabular}

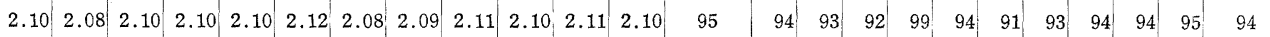

\begin{tabular}{ll|l|l|l|l|l|l|l|l|l|l|l|l|l|l|l|l|l|l|l|l|l|l|}
2.00 & 2.04 & 1.98 & 2.01 & 2.01 & 2.03 & 2.00 & 2.01 & 2.02 & 1.97 & 2.02 & 2.01 & 99 & 97 & 98 & 98 & 99 & 98 & 96 & 97 & 98 & 96 & 98 & 98
\end{tabular}

\begin{tabular}{|c|c|c|c|c|c|c|c|c|c|c|c|c|c|c|c|c|c|c|c|c|c|c|}
\hline $\begin{array}{l}7 \\
\text { メント }\end{array}$ & 2.00 & $\begin{array}{r}2.04 \\
3.18 \\
\end{array}$ & 1.98 & 3.15 & 2.01 & $\begin{array}{r}2.03 \\
3.15\end{array}$ & 2.00 & 2.01 & 2.02 & $\begin{array}{l}1.97 \\
3.16\end{array}$ & \begin{tabular}{ll|l}
2.02 & 2.01 \\
& 3.16
\end{tabular} & 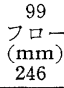 & 21 & \begin{tabular}{l|l}
97 & 98
\end{tabular} & $\begin{array}{ll}8 & 98\end{array}$ & 99 & 227 & 234 & \begin{tabular}{r|r}
97 & 98 \\
225 & 203
\end{tabular} & $|223|$ & 98 & $\begin{array}{l}98 \\
(\mathrm{~mm}) \\
229\end{array}$ \\
\hline & & & 試 & & & 験 & & & & 所 & & & & 試 & & & 験 & & & 所 & & \\
\hline & A & B & D & $\mathrm{E}$ & $\mathrm{F}$ & G & $\mathrm{H}$ & I & J & & 平均値 & A & B & C & D & $E$ & F & G & $\mathrm{H}$ & I & $\mathrm{J}$ & 平均値 \\
\hline
\end{tabular}

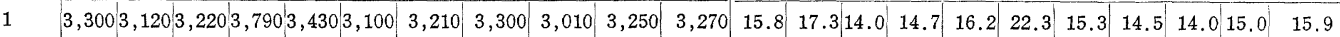

\begin{tabular}{l|l|l|l|l|l|l|l|l|l|l|l|l|l|l|l|l|l|l}
2 & $3,5203,390,3,5104,8303,7503,330$ & 3,540 & 3,530 & 3,420 & 3,370 & 3,620 & 7.7 & 8.4 & 7.0 & 7.3 & 10.1 & 9.5 & 7.9 & 7.6 & 8.0 & 7.5 & 8.1
\end{tabular}

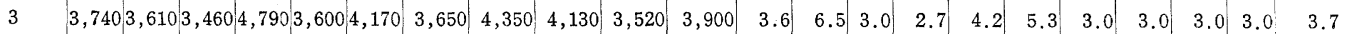

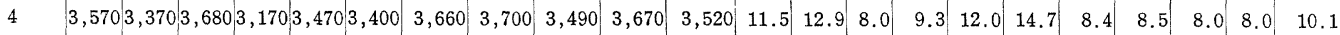

\begin{tabular}{l|l|l|l|l|l|l|l|l|l|l|l|l|l|l|l|l|l|}
5 & $3,6203,5703,6004,1703,5403,440$ & 3,670 & 3,670 & 3,280 & 3,740 & 3,620 & 4.4 & 5.1 & 4.0 & 3.8 & 4.3 & 6.2 & 4.5 & 4.0 & 4.0 & 4.5 & 4.5
\end{tabular}

\begin{tabular}{ll|l|l|l|l|l|l|l|l|l|l|l|l|l|l|l|l|l}
6 & $3,3403,2303,5604,4503,3203,500$ & 3,480 & 3,520 & 3,130 & 3,400 & 3,490 & 11.3 & 12.8 & 10.0 & 12.4 & 11.4 & 18.0 & 11.8 & 12.0 & 12.0 & 11.5 & 12.3
\end{tabular}

\begin{tabular}{l|l|l|l|l|l|l|l|l|l|l|l|l|l|l|l|l}
$2,7402,9402,8303,2802,8703,010$ & 3,000 & 3,130 & 3,180 & 3,090 & 3,010 & 21.6 & 19.821 .0 & 22.0 & 16.0 & 23.3 & 19.0 & 21.0 & 22.0 & 21.0 & 20.7
\end{tabular} セメント $\quad 2,9503,0403,21033,050$

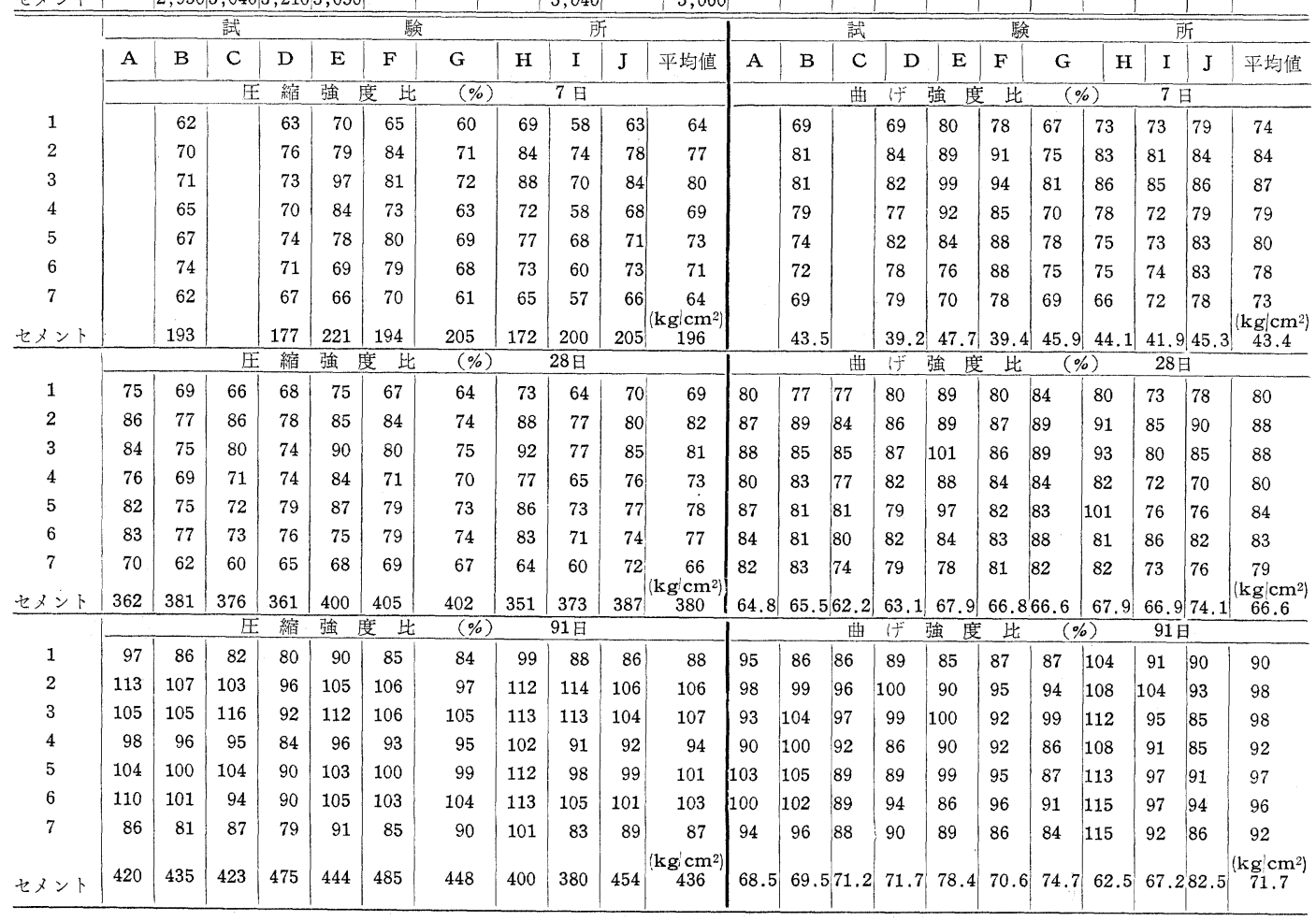




\begin{tabular}{|c|c|c|c|c|c|c|c|c|c|c|c|c|c|c|c|c|c|c|c|c|c|}
\hline \multirow{2}{*}{ 試料番号 } & \multicolumn{3}{|c|}{ 試 } & \multicolumn{2}{|c|}{ 験 } & \multicolumn{2}{|c|}{ 所 } & \multicolumn{2}{|c|}{ 試 } & \multicolumn{2}{|l|}{ 験 } & \multicolumn{3}{|c|}{ 試 } & \multicolumn{4}{|c|}{ 験所 } & \multicolumn{3}{|c|}{ 試験 } \\
\hline & A & B & $\mathrm{E}$ & $\mathrm{F}$ & G & $\mathrm{J}$ & 平均值 & B & $\mathrm{D}$ & & 平均値 & A & B & $\mathrm{E}$ & $\mathrm{F}$ & G & $\mathrm{J}$ & 平均值 & B & $\mathrm{D}$ & 平均值 \\
\hline & \multicolumn{2}{|c|}{ 圧 縮 } & 強 & 度 的 & $(\%$ & 6 & 方月 & \multicolumn{3}{|c|}{ 压縮強度比 $(\%)$} & 1力年 & \multicolumn{2}{|c|}{ 曲 } & 強 & \multicolumn{4}{|c|}{ 此 $(\%) \quad 6$ 力月 } & \multicolumn{3}{|c|}{ 的強度比 $(\%) 1$ 年 } \\
\hline 1 & 111 & 90 & 106 & 100 & 90 & 98 & 99 & 110 & 104 & & 107 & 104 & 107 & 94 & 92 & 109 & 94 & 100 & 104 & 107 & 106 \\
\hline 2 & 127 & 114 & 117 & 117 & 115 & 113 & 117 & 143 & 122 & & 133 & 109 & 102 & 93 & 105 & 113 & 94 & 103 & 118 & 112 & 115 \\
\hline 3 & 125 & 106 & 127 & 122 & 114 & 118 & 119 & 131 & 120 & & 126 & 108 & 108 & 97 & 100 & 100 & 84 & 100 & 118 & 111 & 115 \\
\hline 4 & 119 & 105 & 111 & 108 & 105 & 102 & 108 & 124 & 113 & & 119 & 110 & 101 & 93 & 95 & 107 & 84 & 98 & 104 & 103 & 104 \\
\hline 5 & 107 & 114 & 120 & 115 & 112 & 111 & 113 & 124 & 122 & & 123 & 107 & 128 & 100 & 103 & 97 & 90 & 104 & 116 & 121 & 119 \\
\hline 6 & 119 & 111 & 112 & 116 & 112 & 112 & 114 & 128 & 120 & & 124 & 98 & 105 & 92 & 100 & 109 & 95 & 100 & 112 & 111 & 112 \\
\hline 7 & 97 & 91 & 102 & 102 & 102 & 99 & 99 & 113 & 104 & & 109 & 103 & 100 & 96 & 97 & 113 & 89 & 100 & 105 & 104 & 105 \\
\hline セタント & 432 & 420 & 453 & 483 & 465 & 458 & $\begin{array}{c}\left(\mathrm{kg}^{\prime} \mathrm{cm}^{2}\right\rangle \\
452\end{array}$ & 453 & 460 & & 457 & 69.1 & 64.1 & 79.3 & 70.6 & 70.4 & 83.7 & $\begin{array}{r}\left(\mathrm{kg} / \mathrm{cm}^{2}\right) \\
72.9\end{array}$ & 69.6 & 68.4 & $\begin{array}{r}\left(\mathrm{kg}^{\prime} \mathrm{cm}^{2}\right) \\
69.0\end{array}$ \\
\hline
\end{tabular}

表一4 フライアッシュの品質試験成績表（第 2 回試験）

*印汒 $\left(\mathrm{kg} / \mathrm{cm}^{2}\right)$

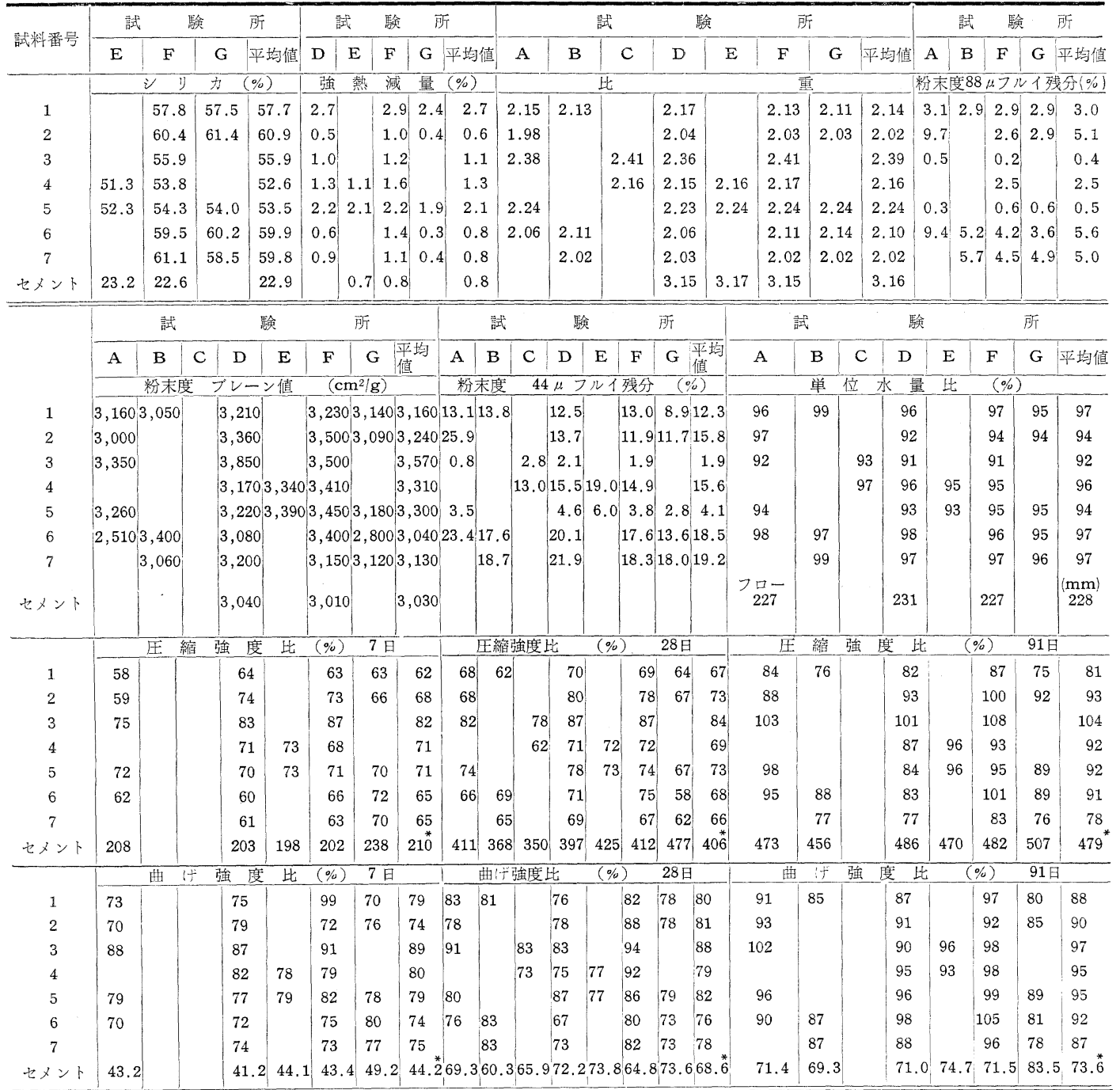

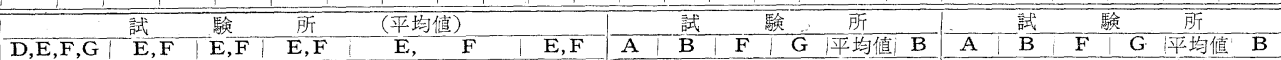

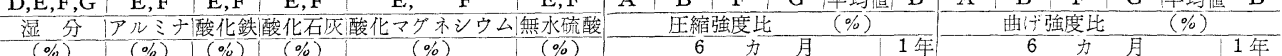

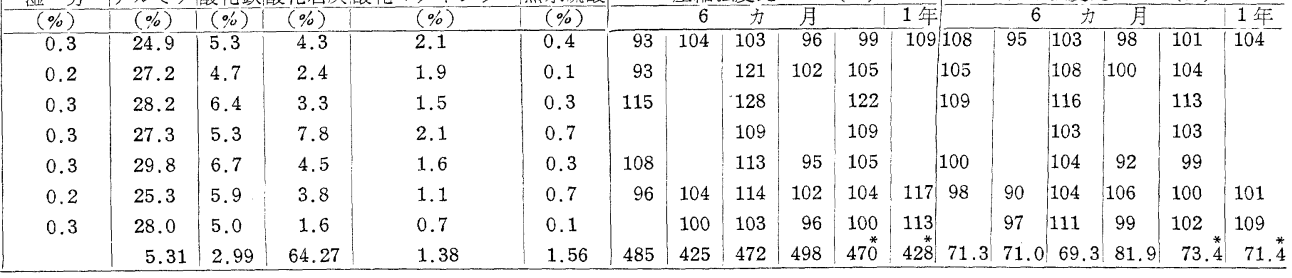


(2) 圧縮強度比の芸験值の変動係数は, 材令 28 日で 5.5 8\%, 材令 91 日で $5 \sim 7.2 \%$, 材令 6 力月で 3 〜 8.5\%であつて相当に大きい。この原因としては種々のことが考光られるが, フライアッシュを用いない供試体 の試験值の変動が意外にいらじるしいことも大きな原因と考光られる。工事現場に和けるフライアッシュの管理 試験に当つては，強度試験の誤差を小さくするように努力しないと好結果が得られないことを示するのである。

\section{2. 第 3 回の品質試験結果}

第 3 回の品質試験の結果は 表一5 亿示すようであつて, ほとんど大部分のものが JIS の規定に合格し，フライ アッシュ 202 招よび 105 の圧縮強度比だけが，少数の試験所で不合格となつている。

しかし，第 1 回扔よび第 2 回の試験結果と同様に，19 種のフライアッシュの品質には大差が認められる。 な技，明瞭飞結論することはできないが，工場から直接採取したフライアッシュと工事現場から採取したフラ イアッシュとで品質の相違があつたことは認められない。

\section{3. フライアッシュの各種試験值について}

第 1 回, 第 2 回括よび第 3 回の試験結果をぬとめると, 合計 33 種のフライアッシュの試験值（各試験所とお ける試験值の平均值) は次の上うであつて, 湿分, 比重, 等は大差ないが, その他怔 JIS 飞不合格となることは ほとんどないが，相当の広範囲に相違している。

\begin{tabular}{|c|c|c|c|c|}
\hline & & & 規 格 値 & 試 験 值 \\
\hline i & リ & 力 & $45 \%$ 以上 & $63 \sim 48 \%$ \\
\hline 湿 & & 分 & $1 \%$ 以下 & $0.1 \sim 0.5 \%$ \\
\hline 強至 & 熱 減 & 量 & $5 \%$ 以下 & $0.1 \sim 2.7 \%$ \\
\hline 比 & & 重 & 1.95 以上 & $2.40 \sim 2.00$ \\
\hline \multirow{2}{*}{ 粉末度 } & \multicolumn{2}{|c|}{ プレーン方法 } & \multicolumn{2}{|c|}{$2,700 \mathrm{~cm}^{2} / \mathrm{g}$ 以上 $3,910 \sim 2,920 \mathrm{~cm}^{2} / \mathrm{g}$} \\
\hline & \multicolumn{2}{|c|}{$\mid \begin{array}{c}44 \mu \text { 方るい } \\
\text { 残分 } \\
\end{array}$} & $25 \%$ 以下 & $1.7 \sim 20.7 \%$ \\
\hline
\end{tabular}

\begin{tabular}{|c|c|c|c|c|}
\hline & & 規 格 値 & 誈 験 & 值 \\
\hline 単位水岳 & 比 & $100 \%$ 以下 & $92 \sim 98 \%$ & \\
\hline & 28日 & $63 \%$ 以上 & $87 \sim 64 \%$ & \\
\hline 圧縮強度比 & 91日 & $80 \%$ 以上 & $107 \sim 78 \%$ & \\
\hline & 6 力月 & - & $121 \sim 91 \%$ & \\
\hline & 28日 & - & $89 \sim 69 \%$ & \\
\hline 曲计強度比 & 91日 & - & $104 \sim 84 \%$ & \\
\hline & 6 力月 & - & $118 \sim 92 \%$ & \\
\hline
\end{tabular}

圧縮強度比も曲げ強 度比も, フライアッシ ュによつて大差はある が、いずれも,材令とと も増加し， 3 力月以 後の材令に和いては, ほとんど全部のフライ アッシュが，85\%以上 となつている。図一1 はとの一例を示したも のである。しかしこれ らの強度比が, 用いる セメントの化学成分 (特任硅酸三石灰招上 びアルカリ) ならびに 粉末度, 等飞よつて相 違することは当然であ る。また, 各試験值が フライアッシュねよつ て広範囲飞相違してい ることは, フライアッ シュの使用に当り, 試 験を行うことがぜひ必 要であることを示すも のである。
図一1 第 1 回試験におけるフライアッシュの強度比（平均值を示す）
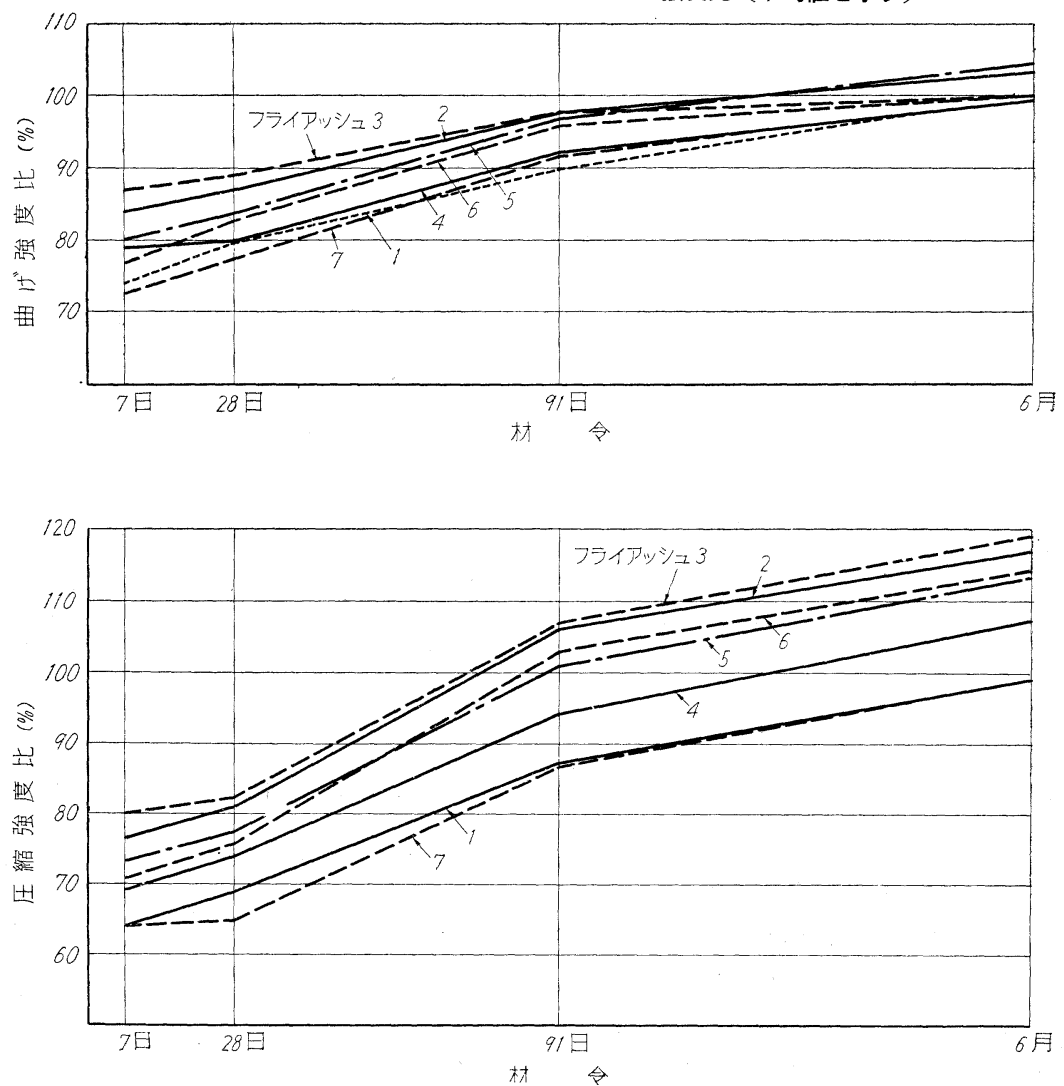
フライアッシュの相違による玧度 比の差は, 短期材令の場合をのぞけ ば曲げ強度比上りも圧縮強度比飞括 いていちじるしい(表一11参照)。こ れは品質を試験するためには曲げ強 度比よりる圧縮強度比による方が適 当である事を示するのと思われる。

図一2〜6 はフライアッシュの強 熱減量, ブレーン值, $44 \mu$ ふるい 残分, 単位水量比, 圧縮強度比, 等 の相互の関係を示したるのである。

図一3 亿示す上うにある一工場の試 験值江打いては $44 \mu$ ふるい残分と ブレーン值とは添济比例している。 しかし，図一2 に示されたごとく試 験值全般から見れば, $44 \mu$ ふるい 残分とブレーン值との間関連性は 認めにくい。これは、33種のフライ アッシュの性質が相当に相違してい ること, 試験の誤差が大きいこと， 等に上るものと思われる。しかし， 工場江打甜る品質管理のためには， $44 \mu$ ふるいを用いてもブレーン方 法を用いて子大差無いことは示され ている。

図-4 法 $44 \mu$ らるい残分と強熱 減量との関係を示したものである が, これらの間注関連性は認めら れない。図一-5 は粉末度と材令 91 日飞括仔る区縮強度比との関係を示 したものであつて，明らかではない が, 細かいもの注ど強度比が大きく なる傾向は認められる。明膫な傾向 か沶されないのは, 試験したフライ アッシュがいずれも相当に粉末の細 かいるのであつたことによると思わ れる。

図一6 政学位水量比と材令 91 日 そ扔ける圧縮強度比との関係であつ て, これらの間には比例関係が鯰め られる。従つて単位水量比の試験は フライアッシュの品質判定上特に重 要なるのと思われる。

以上に述べた結果は,フライアッ シュの品質を論ずる場合, JIS の諸 項目についての試験値を各個に比較 して論ずるのは適当でないのであつ て, 単位水量比括よび圧縮強度比の
图一2 $44 \mu$ ふるい残分とブレーン值との関係（第 1 回, 第 2 回および第 3 回 試験）

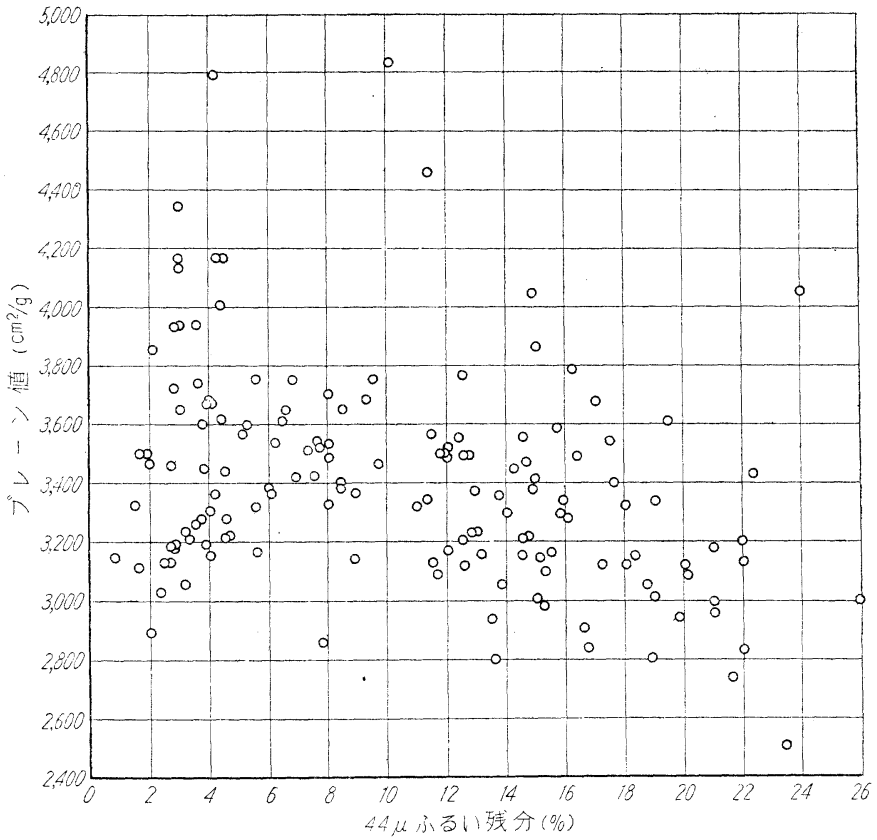

図一3 ある工場で調查した $44 \mu$ ふるい残分とブレーン値との関係

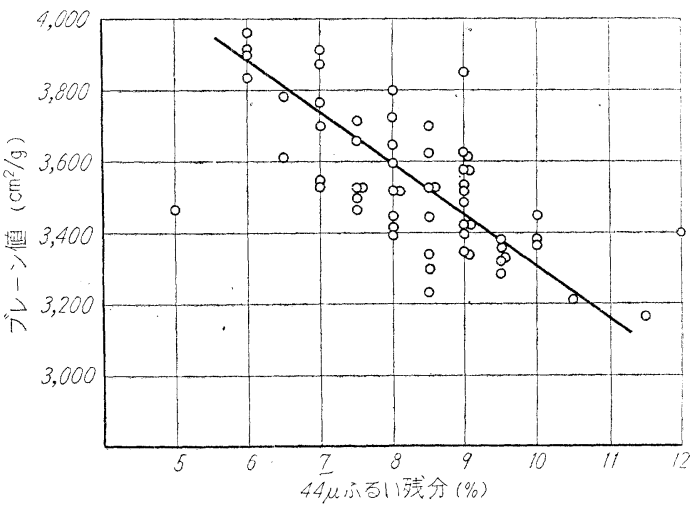

図-4 $44 \mu$ ふるい残分と強熱隇量との関係（第 1 回，第 2 回および第 3 回試 験)

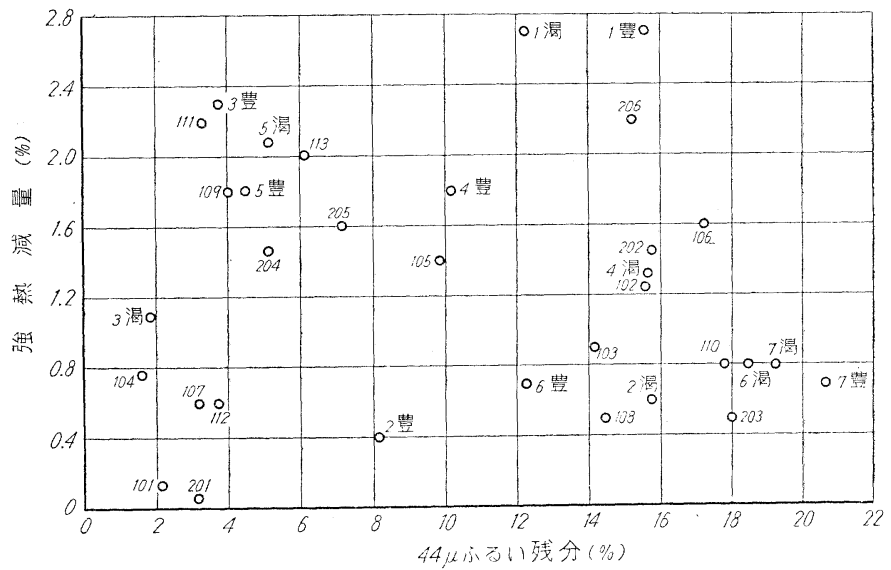

注：数字はフライアッンュの番号を示す。 
試験值とともに総合して判断する必要のあることを示するのである。しかし，今回試験した試料といちじるしく 異なるようなフライアッシュの場合には, 強熱減量, 粉末度, 等もとの品質を判定するための良いめやすとなる ものと思われる。

図一5 $44 \mu$ ふるいの残分と材令 91 日における圧縮強度比との関係（第 1 回，第 2 回および 第 3 回試験）

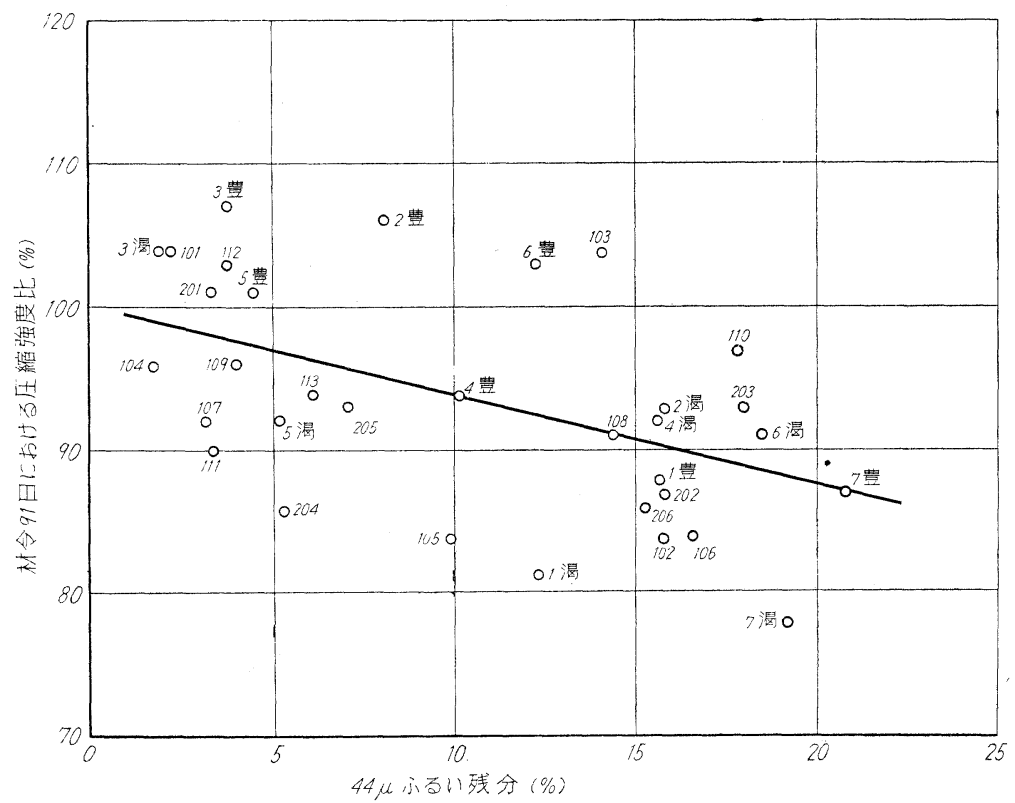

注 : 数字はフライアッシュの番号走示す。

図一6 単位水量比と材令 91 日における圧縮強度 比との関係（第 1 回, 第 2 回および第 3 回 試験)

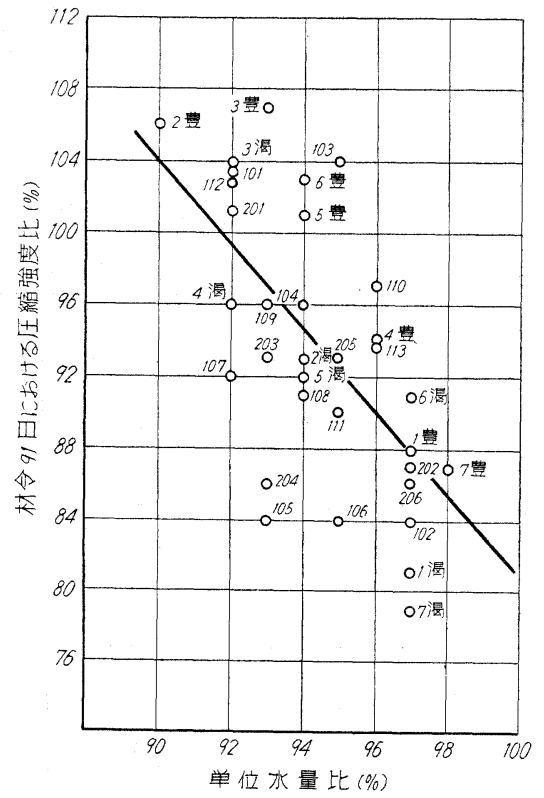

注 : 数字はフライアッンュの番号を示す。 
表一5 ラライアッシュコ品質

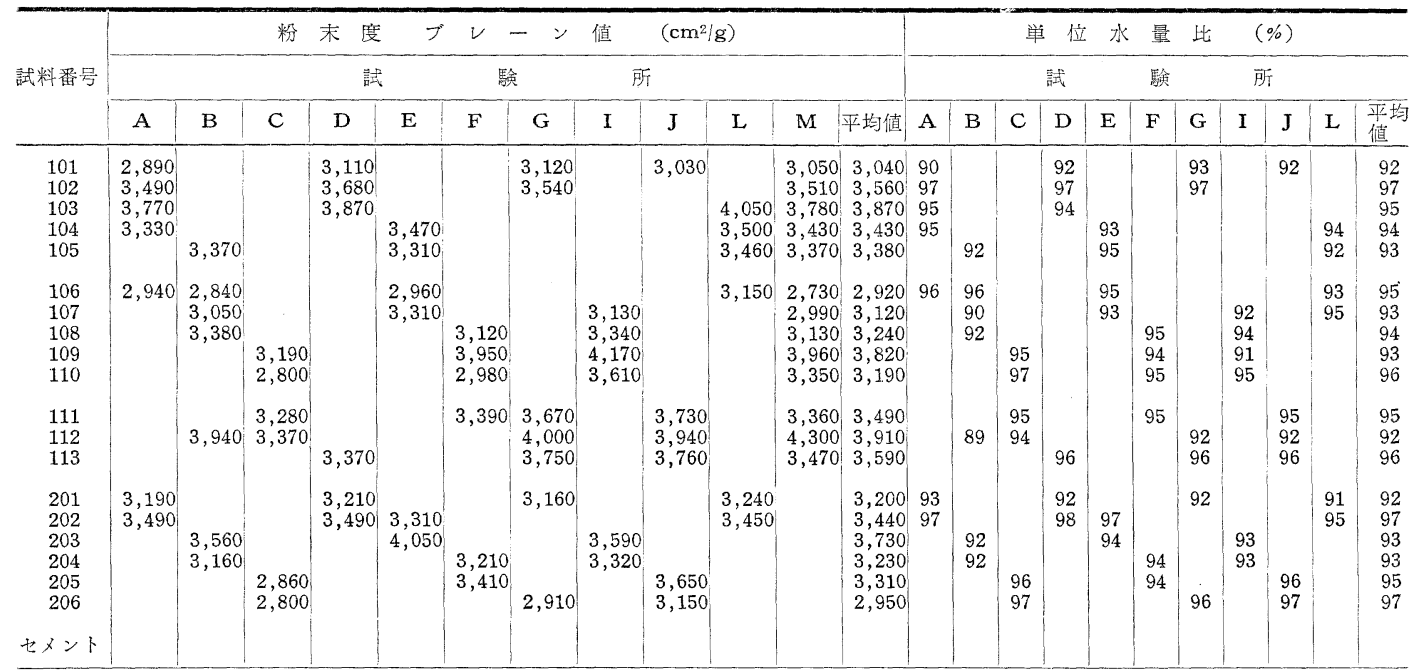

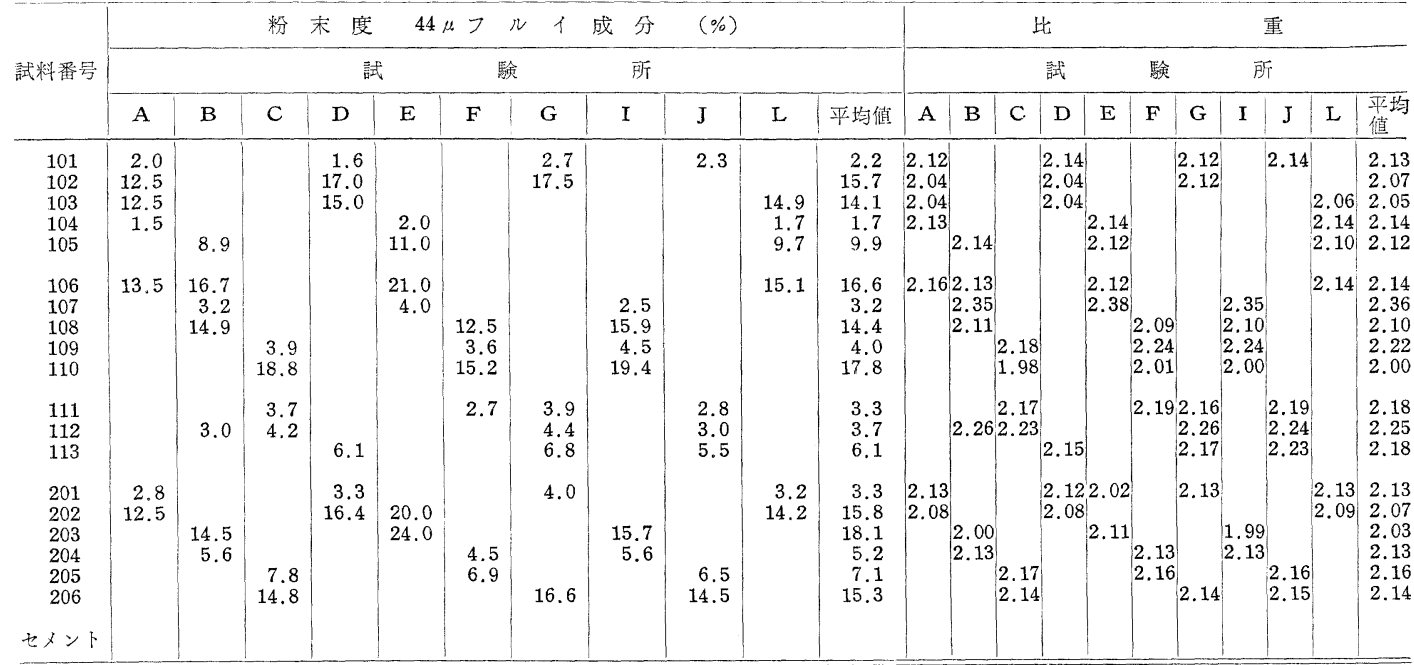

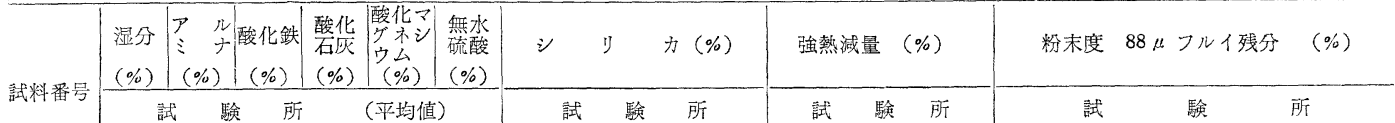

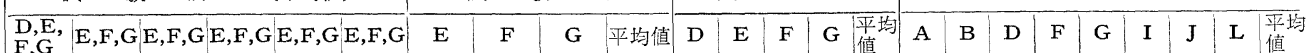

\begin{tabular}{|c|c|c|c|c|c|c|c|c|c|c|c|c|c|c|c|c|c|c|c|c|c|c|c|c|}
\hline 101 & 0.1 & 5.4 & 4.0 & 4.7 & 1.3 & 0.1 & 61.8 & 60.9 & 60.7 & 61.1 & 0.1 & 0.2 & 0.1 & 0.1 & 0.1 & 0.6 & & 0.2 & & 0.3 & & 0.2 & & 0.3 \\
\hline 102 & & & 4 & 1 & 0.8 & & 60.4 & 62.0 & 61 & 61.3 & 1.1 & 1.2 & 1.3 & 1.3 & 1.2 & 3.3 & & 2.6 & & & & & & 8 \\
\hline 103 & 0.1 & & 5 & 2. & 1. & 0. & 59 & 60. & 60 & 60.2 & 0.7 & 0.7 & 1.1 & 0.9 & 0.9 & 5.2 & & 5.7 & & & & & 5.0 & 5.3 \\
\hline 104 & 0.2 & 27.3 & & 4.9 & 1. & & & & 55 & 55. & & 1.0 & & 0.8 & 0.9 & 0.5 & & & & & & & 0.7 & 0.6 \\
\hline 105 & 0.2 & 26.1 & 4. & 4.9 & 1.5 & 0.6 & & & 58.1 & 58.3 & & 1.5 & 1.4 & 1.2 & 1.4 & & 1.4 & & & & & & & \\
\hline 106 & 0.3 & 5.0 & 7.6 & 3.7 & 1.8 & 0.5 & 5.7 & 57.4 & 56.6 & 56 & & 1.6 & 1.6 & 1.6 & 1.6 & 4.4 & 4.3 & & & & & & 4.3 & 4.3 \\
\hline 107 & 0. & & & & 1. & & & & & & & 0.6 & & & & & & & & & 1.0 & & & \\
\hline 108 & 0.1 & 26 & 6. & 4 & 1. & & & & & 58 & & 0.5 & 0.6 & 0.4 & 0.5 & & 4 & & 4.5 & & 3.1 & & & \\
\hline $\begin{array}{l}109 \\
110\end{array}$ & $\begin{array}{l}0.5 \\
0.2\end{array}$ & $\begin{array}{l}26.0 \\
29.0\end{array}$ & 5. & $\begin{array}{l}4.3 \\
2.1\end{array}$ & $\begin{array}{l}1.6 \\
1.1\end{array}$ & & & & $\begin{array}{l}57.3 \\
61.2\end{array}$ & $\begin{array}{l}57.2 \\
61.1\end{array}$ & & $\begin{array}{l}1.8 \\
0.8\end{array}$ & $\begin{array}{l}2.1 \\
0.9\end{array}$ & $\mid \begin{array}{l}1.5 \\
0.8\end{array}$ & $\begin{array}{l}1.8 \\
0.8\end{array}$ & & & & $\begin{array}{l}0.9 \\
6.7\end{array}$ & & $\begin{array}{l}1.2 \\
6.8\end{array}$ & & & $\begin{array}{l}1.1 \\
6.8\end{array}$ \\
\hline 110 & 0.2 & 29.0 & & 2.1 & & & & & & & & & & & & & & & & & & & & \\
\hline 111 & 0.3 & 24.0 & 9. & 3.5 & 1.7 & 0. & 55.9 & 56.9 & 56.4 & 56 & & 2. & 2.3 & 2.2 & 2.3 & & & & 0.5 & 0.4 & & 0.4 & & \\
\hline 112 & 0.2 & & 6 & & 2 & & & & 60 & 7 & & 0 & 07 & $0.5 \mid$ & & & 0.7 & & & & & & & \\
\hline 113 & 0.3 & 26.2 & 4.4 & 4.1 & 2. & & 57.7 & 57.4 & 57.3 & 57.5 & 2.0 & 1.9 & 2.3 & 2.0 & 2.1 & & & 1.3 & & 1.3 & & & & 1.2 \\
\hline 201 & 0.1 & 26 & 3. & 5.2 & 1.2 & 0.2 & 60.2 & 60.8 & 60.5 & 60.5 & 0.1 & 0.1 & 0.1 & 0.1 & 0.1 & 0.8 & & 1.2 & & 0.3 & & & $\frac{1.2}{3}$ & 0.9 \\
\hline & 0.2 & & 4. & 2 & 0. & 0. & 62.3 & 62.7 & $\begin{array}{r}62.0 \\
61.7\end{array}$ & 62.3 & $\mid 1.4$ & 1.4 & 1.6 & 1.5 & 1.5 & 3.3 & $44^{1}$ & 1.2 & & & 40 & & 3.4 & 42 \\
\hline 203 & $\begin{array}{l}0.1 \\
0.3\end{array}$ & $\begin{array}{l}27 \\
27\end{array}$ & 4. & 2. & $\begin{array}{l}1.2 \\
1.8\end{array}$ & 0.4 & 56 & $\begin{array}{l}6.4 \\
57.0\end{array}$ & 56.1 & $\begin{array}{l}02 \\
56\end{array}$ & & $\begin{array}{l}0.5 \\
1.3\end{array}$ & $\begin{array}{l}0.5 \\
1.5\end{array}$ & $\begin{array}{l}0.0 \\
1.4\end{array}$ & $\begin{array}{l}0.0 \\
1.4\end{array}$ & & $\begin{array}{l}4.4 \\
0.7\end{array}$ & & 0 & & $\begin{array}{l}.0 \\
0.6\end{array}$ & & & \\
\hline 205 & 0. & 26 & 5. & & 1. & 0. & 56 & 57.6 & 56.9 & 56 & & 1.5 & $\begin{array}{l}1.7 \\
1.7\end{array}$ & 1.6 & 1.6 & & & & 1.5 & & & 1.1 & & 1.3 \\
\hline 206 & 0.3 & 25.3 & 6.5 & 3.1 & 1.6 & 0 & 56.0 & 57.1 & 57.1 & 56.7 & & 2.4 & 2.3 & 2.1 & 2.3 & & & & & 1.4 & & 2.5 & & 2.0 \\
\hline メン & & 4.84 & 3.16 & 65.32 & 1.48 & 1.48 & & & & & & & & & & & & & & & & & & \\
\hline
\end{tabular}


試 験 成 績 表（第 3 回試験）

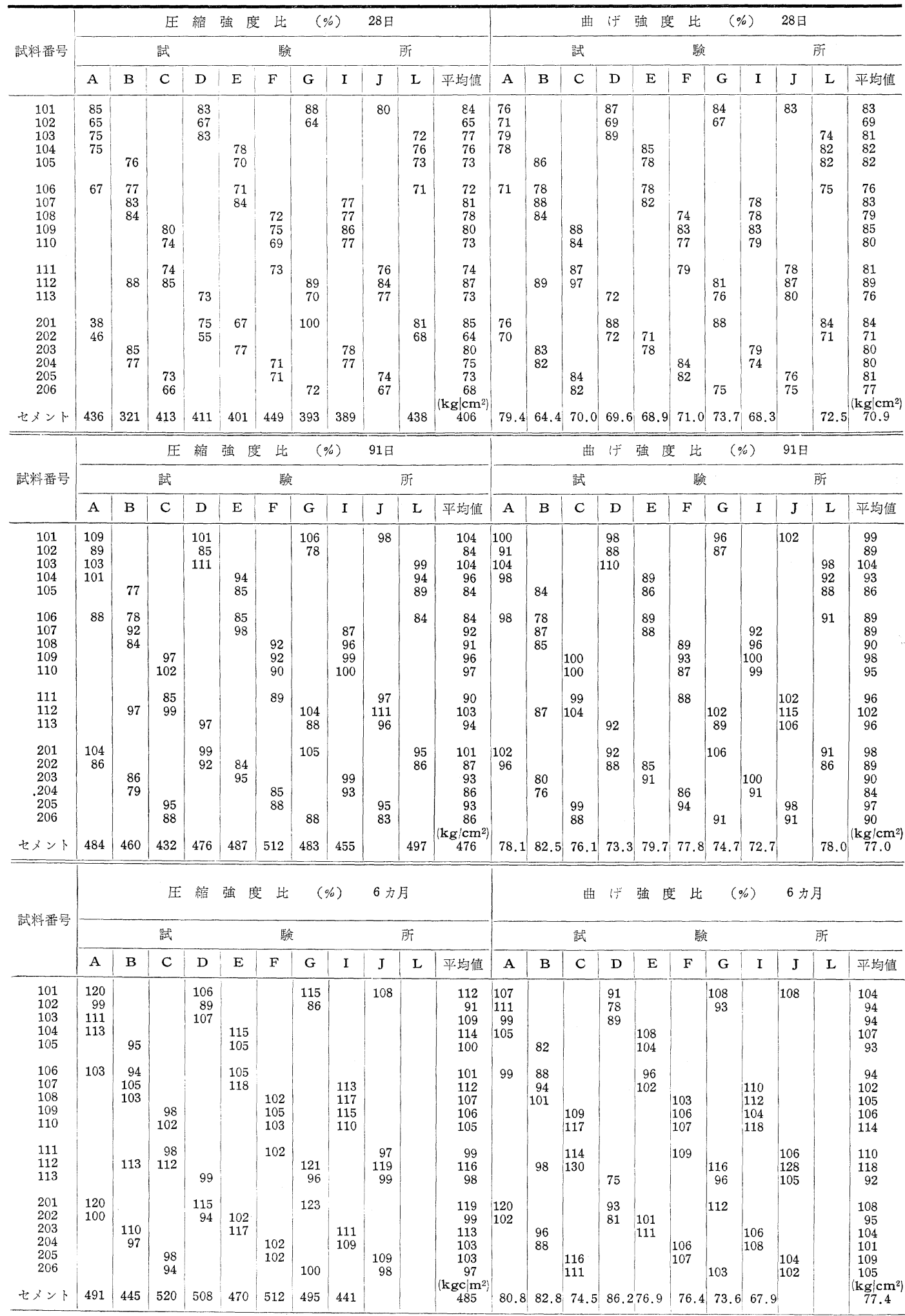




\section{第 4 章 各種フライアッシュがコンクリートのウォーカビリチー および強度におよぼす影響}

第 2 章に述ベたように，単位セメント量 $300 \mathrm{~kg}$ のコンクリートと同じウォーカビリチーを持つコンクリート を，単位セメント フライアッシュ量 $(C+F) 300 \mathrm{~kg}$ フライアッシュによるセメントの稆き換光率 $(F / C+F) 25$ \%として各種のフライアッシュを用いて造り，単位水量衫よび強度をそれぞれフライアッシュを用いない場合の 数值で割り，単位水量比招上び強度比を求めた結果は表一6 招よび 表一7 と示すようであつた。表一6 扮よび 表一7 ふら次のことが認められる。

（1） $\mathrm{AE}$ コンクリートの場合にも $\mathrm{AE}$ 剽を用いないコンクリートの場合にも，単位水量比は，JIS 飞規定 するモルタル試験に拈ける単位水量比より減じ，20 種のフライアッシュに招いて 89〜96\% となつていて，い ずれのフライアッシュるこれの使用によつてコンクリートのウォーカビリチーが改善されることが明瞭に示され ている。

（2）それぞれのフライアッシュについて, 報告されている単位水量比の各試験所間に拈ける相違は JIS の 単位水量比の試験值に招ける相違よりもい方じるしくなつている。これは, 試験所ごとに骨材が相違していたこ と, ウォーカビリチーの判定に相違があつたこと, 等によると思われる。それで全試験值についてみれね゙, コン クリートに招ける単位水量比と JIS の単位水量比との間飞一定の関係があるとは認められないようになつてい る。しかし，それぞれの試験所だけについて試験值を整理すれば, 図一7に示すように，これらの2種の単位水 量比の間に犆線的な関係があると認められる。従つて JIS K規定する単位水量比はコンクリートの場合の単 位水量比を推定するめやすとして役立つるのである。

表一6 フライアッシュがコンクリートの単位水量および圧縮強度におよぼす影響（第 2 回試験）

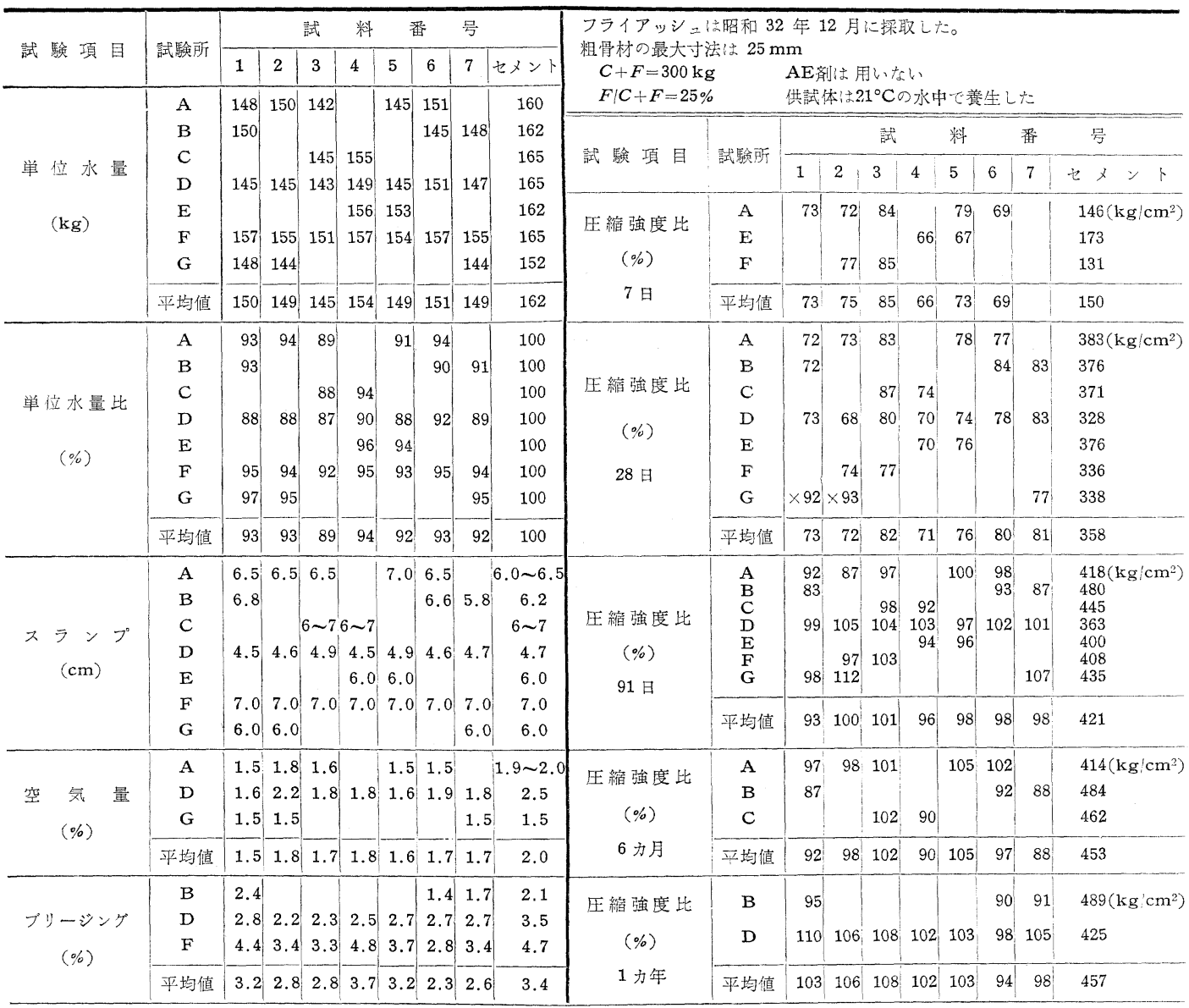


（3）王縮強度比は，JIS 亿規定する圧縮強度比よりも大となり，材命 3 力月以後に呿いては大部分が $95 \%$ 以上となり，100\% を超元るものも数種ある (図一8 参照)。をた, 引張強度比も圧縮強度比と同程度の值となつ ている。これは, 乾燥しにくい場所のコンクリートでは, セメントの適当量をフライアッシュで抬き換えても, 長期飞招いては同等以上の強度㧍よび氷密性が得られるととを示するのである。第 2 回試験に招いてJIS の規格 飞不合格となつたフライアッシュでも, コンクリートに括ける圧縮強度比は材令 28 日で $81 \%$, 材令 3 カ月以後 では 90\% 以上となつている。これは, JIS の圧縮強度比の規格に不合格となるものでも実用に供し得る場合が あることを示するのであつて，JIS の標準試験だけでなくコンクリートとついてもフライアッシを試験するこ とが必要である。

（4）第 3 章, 1.亿述べたごとく, 同種のフライアッシュの試料に括いても, 採取時期が異なつた場合にいる じるしい品質の相違が認められたるのがある。図一-9 は第 1 回試験（豊水期に採取した）と第 2 回試験（渴水期 飞採取した）とに括ける圧縮強度比の相違を示したすのであつて，フライアッシュ 1,3 招よび 5 は大差無い が，2怙よび 6 亿括いては大差が認められる。図一10 はこれらのフライアッシュを用いたコンクリートの圧縮 強度比の 試験所 A 飞招ける試験值がめつて, コンクリートに招いても全く同様な相違が認められる。これらの

表一7 フライアッシュが $\mathrm{AE}$ コンクリートの単位水量および強度におよぼす影響（第 3 回試験）

フライアッンュは昭和 33 年 10 月に採取した。

粗骨材の最大寸法 $=25 \mathrm{~mm}$, 単位セメント フライアッン二量 $(C+F)=300 \mathrm{~kg}$,

フライアッンュによるセメントのおき換え率 $(F / C+F)=25 \%$ 供試体は $21^{\circ} \mathrm{C}$ の水中で責生した。

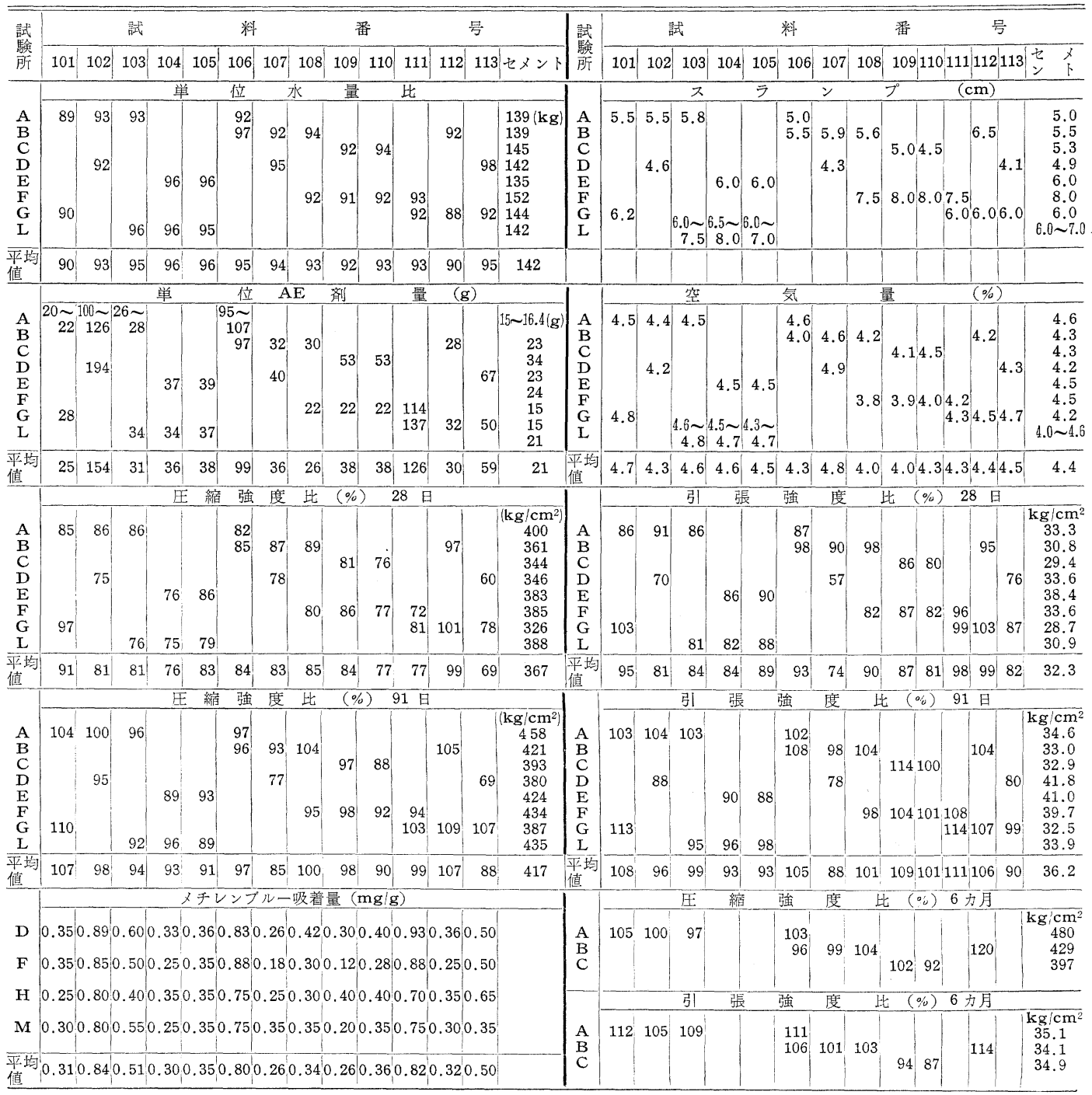


結果は, 重要な工事に用いる場合にはフライアッシュの品質管理に, 特に注意する必要のあることを明瞭に示す るのである。

（5）コンクリートの空気量を 4〜5\% とするに必要な 単位 $\mathrm{AE}$ 剂量 はいずれのフライアッシュの場合にも フライアッシュを用いない場合より增加し 表一7 亿示すごとく, 13 種のうちの 102, 106, 111, の 3 種では 5 倍以上になつている。これは主として, フライアッシュ中の活性炭素に AE 剤 が吸着されることによるもので

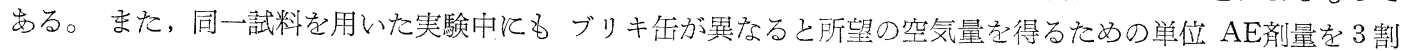

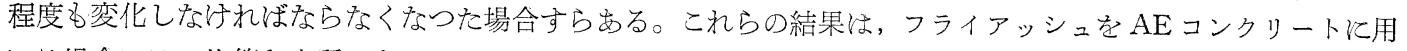
いる場合には，均等な良質のものでない限り空気量の変動が大きくなり、コンクリートの管理が困難になること を示するのである。この困難を解決する実用的な方法は, フライアッシュを粉末のまま使用せず, あらかじめ水 にとかしペーストとして使用する方法であると筆者は信じている。

炭素含有量の多いフライアッシュでは, 上記のような困難がともなうほかに, これを用いたコンクリートの品

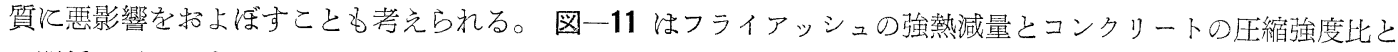
の関係を示したものであるが，試験に用いたフライアッシュの範䧃内では関連性はあまり認められない。それ で, 安る程度まで強熱減量の多いものでも, 均等質のものであれば, $\mathrm{AE}$ 剽を用いないコンクリートには十分に 使用できると思われる。

（6）図一12 は 各フライアッシュのメチレンブルーの财着量と所望の空気量を得るに必要な単位ビンゾール 量との関係を示したものであつて, 単位ビンゾール量はフライアッシュを用いないコンクリートに括汸る単位ビ ンゾール量の倍数で表わしてあり,フライアッシュごとに二つの試験所㧠ける試験值が示してある。図一12 か

\section{図一7 コンクリートにおける単位水量比と JIS に規定する \\ モルタル試験における単位水量比との関係}

（第 2 回および第 3 回試験）

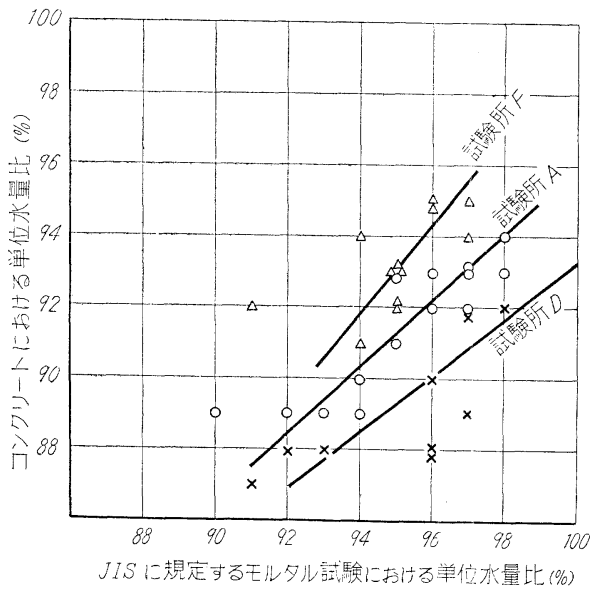

図一8 フライアッシュを用いたコンクリートにおける圧縮強度比（第 2 回試験）

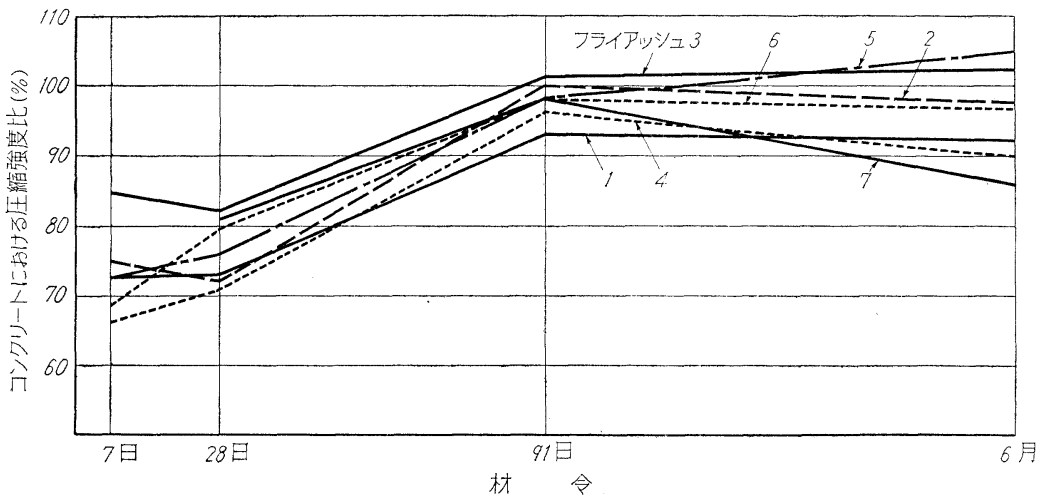

注 : 平均值を示す。 
ら,メチレンブルーの吸着量の多いるのほど単位 $\mathrm{AE}$ 剂量が増加し, その増加する程度は吸着量が多くなるほ ぞいちじるしくなることが認められる。図一13 溞熱減量とメチレンブルーの吸着量との関係を示したるので

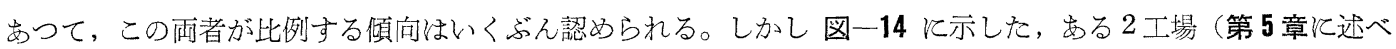
るIII とIV)で連続して採取した 60 試料と括けるメチレンブルーの吸着量と強熱減量との間には, 関連性を認め にくい。乙れは主として, 強熱減量が活性炭素量に比例しなかつたことによると思われる。また, この 2 工場に 拈ける強熟減量は約 $1 \%$ であつて 60 試料飞和けるその変動の範囲は $0.5 \%$ 程度飞過ぎない。メチレンブルー の吸着量の陚験は活性炭素量のこのような少差を示せるほど鋭敏なるのではないので, 図一14では関連性が認 められなくなつたものとも思われる。

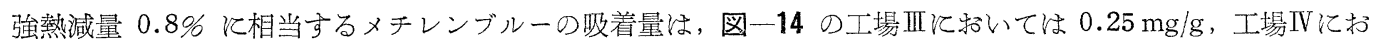

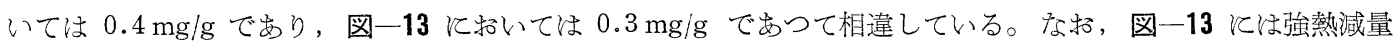
$1.6 \%$ 亿相当するメチレンブルーの吸着量は, 大部分が $0.5 \sim 0.9 \mathrm{mg} / \mathrm{g}$ 以上であるのにわずか $0.25 \mathrm{mg} / \mathrm{g}$ 程度 となるフライアッシュもあることが示されている。これは,強熱減量が活性炭素量飞比例しないこと掠よびる紙

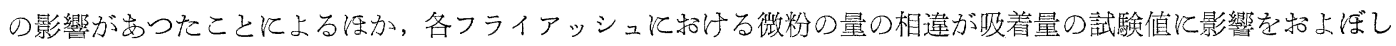
たことにるよると思われる。

上記のようにメチレンブルーの吸着量と強熱減量とは比例的な関係にあるとは限らないが，図一12 から推定 すれば，ある一種のフライアッシュを用いる工事現場と扔いては,メチレンブルーの吸着量の試験は AE コン クリートの管理に有効であると思われる。しかし武料の採取には十分な注意が必要であろう。

吸着量試験飞招いて比色を行うために, 溶液中のフライアッシュを分離するには溶液をる過する代りに遠心分

図一9 第 1 回試験（豊水期に採取した）と第 2 回試験（渇水期に採取した）とにおける フライアッシュの圧縮強度比の相違
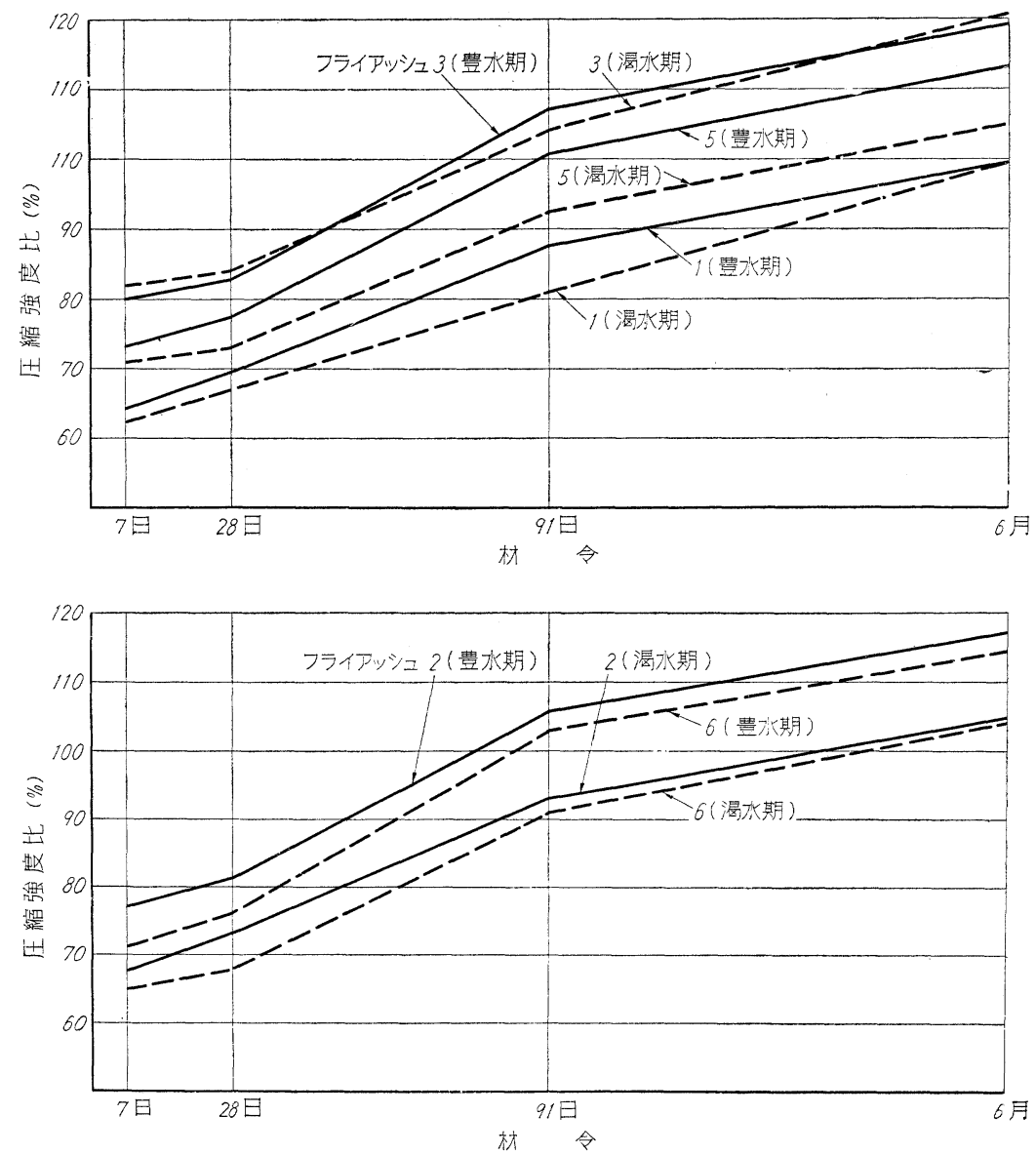

注 : 平均值を示す。 
離器を用いることが考光られる。図一15 は試験所Aで行つた遠心分離方法によるメチレンブルー吸着量の試験 值をる過方法による試験值と対比したものであつて, 毎分約 400 回転で 5 分間遠心分離したものである。実験 の数は少ないが，遠心分離の方法が，精度の良いことを暗示するものと思われる。また，遠心回転数を増加すれ ば所要時間も短縮されるのであつて, 便利な方法であると思われる。

図一10 第 1 回試験（豊水期に採取した）と第 2 回試験（渴水期に採取した）とにおける フライアッシュを用いたコンクリートの圧縮強度比の相違

（試験所 A における実験）
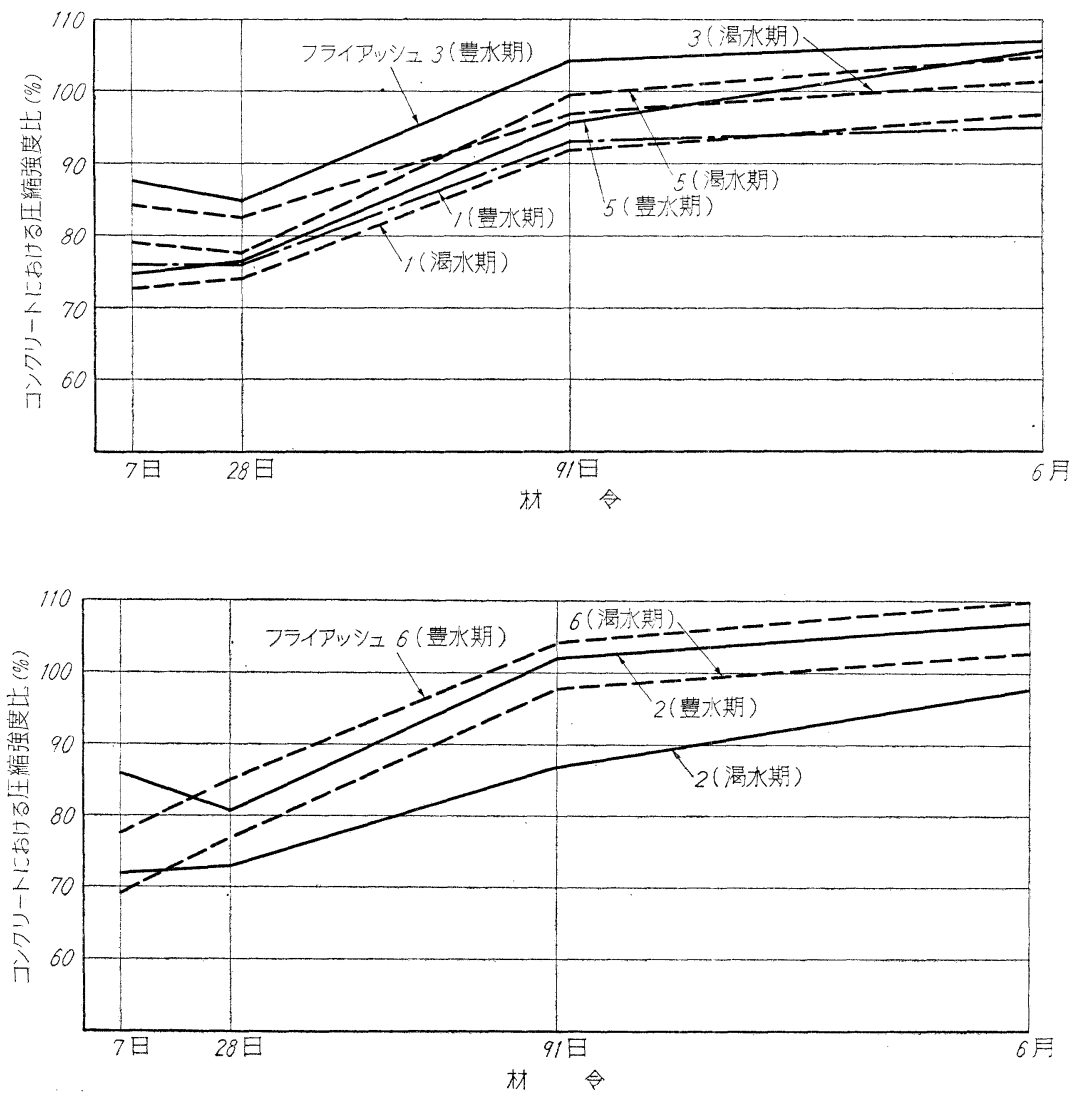

図一11 フライアッシュの強熱減量とコンクリートの圧縮強度比 との関係（第 2 回および第 3 回試験）

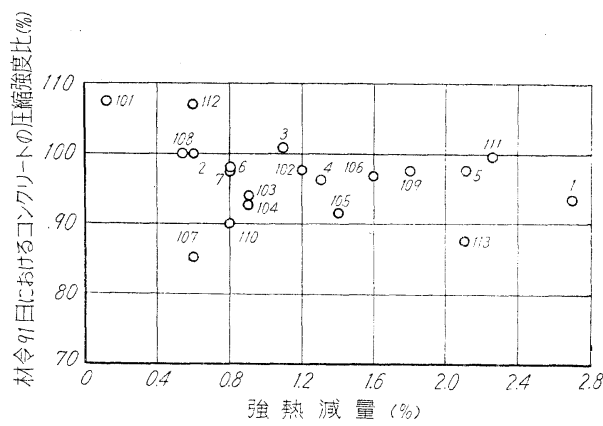

注 : 数宇はフライアッンュの番号を示な゙。 
図一12 メチレンブルーの吸着量と AE コンクリートの単位ビンゾール 量との関係（第 3 回試験）

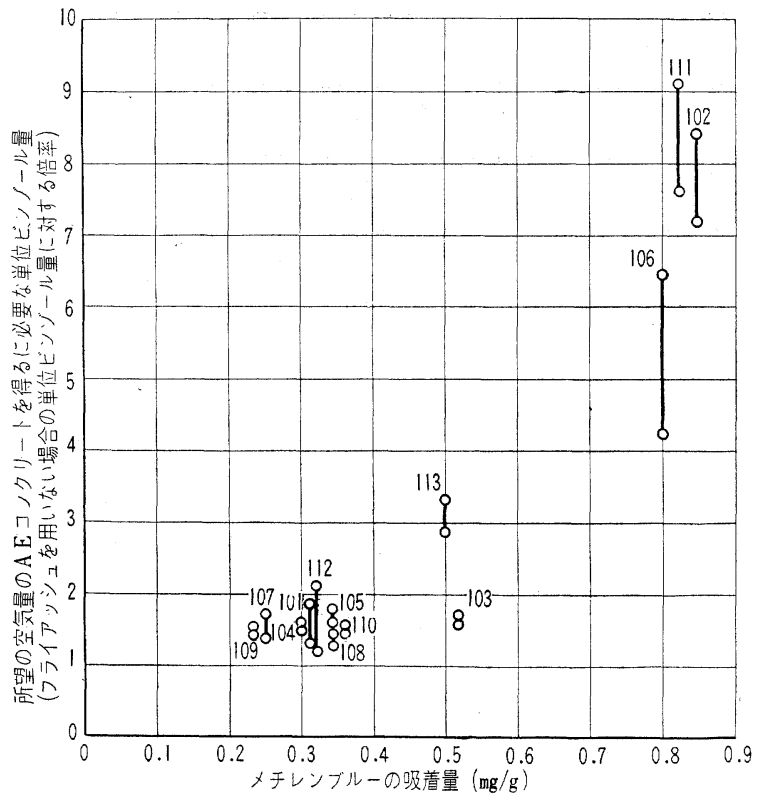

注：単位ピンソ゚ール县は 2 試験所における試験值を示したものであ つて，数字はフライアッンュの番号を示したるのである。

図一13 各種フライアッシュにおける強熱減量とメチレンブルーの吸着量との関係 (第 3 回試験)

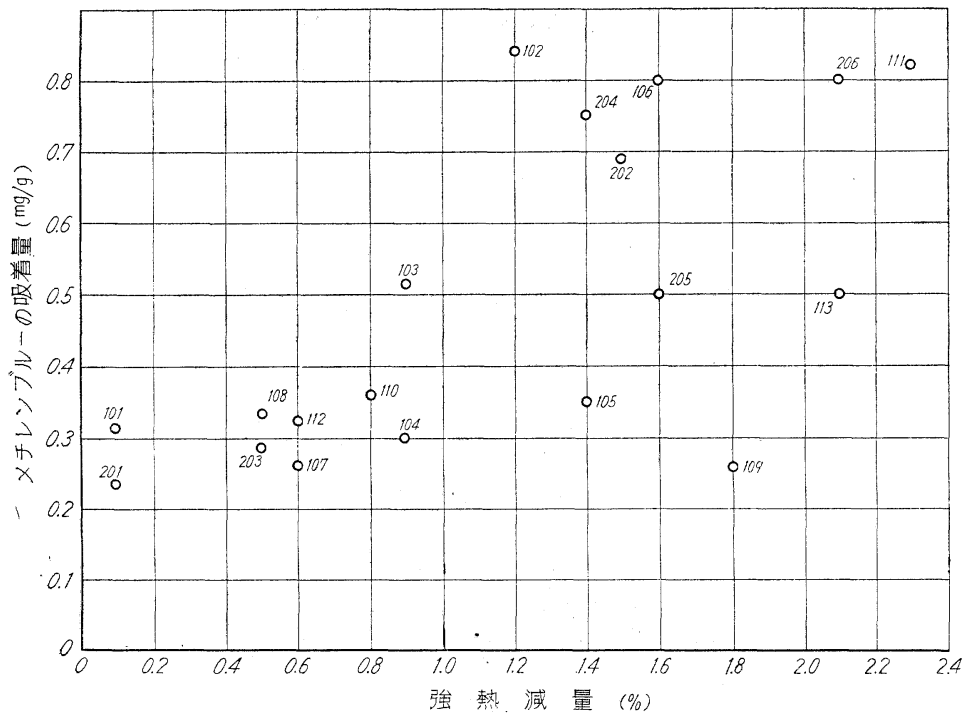

注 : 数字はフライアッンュの番号を示す。 
図-14 ある工場で調査した強熱減量とメチレンブルーの吸着量との関係
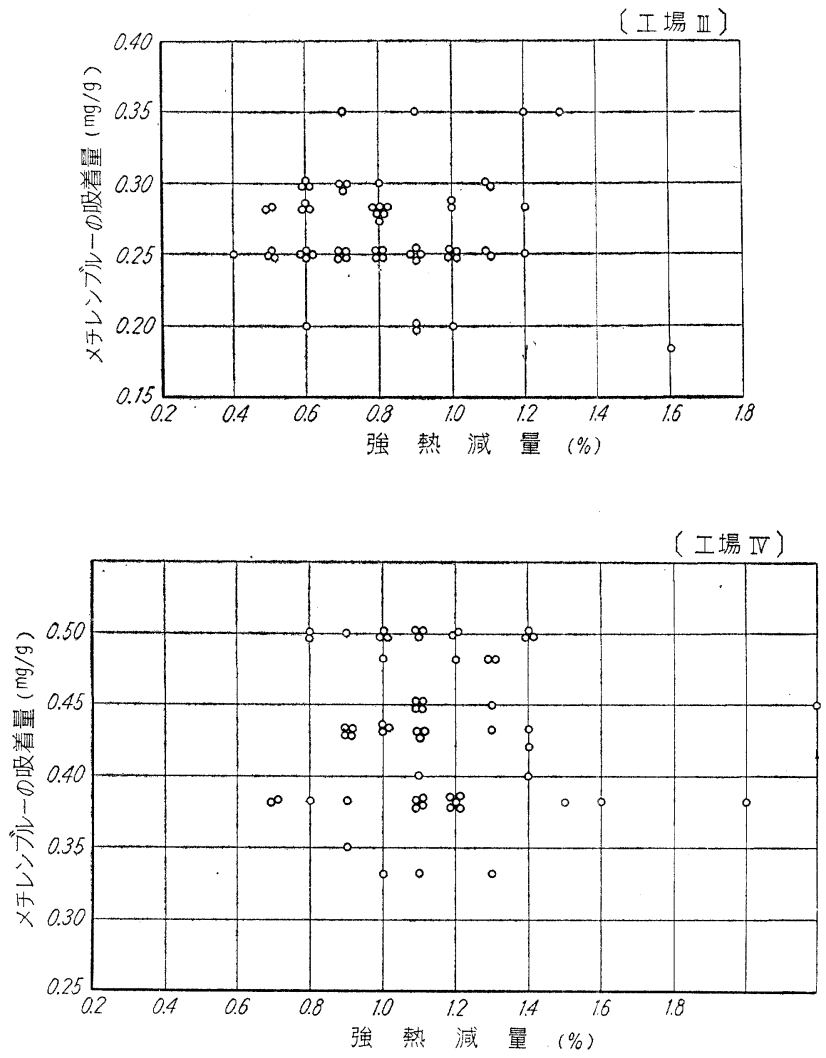

図一15 試験方法の相違がメチレンブルーの吸着量試験值に およぼす影響（試験所 $\mathbf{A}$ における実験）

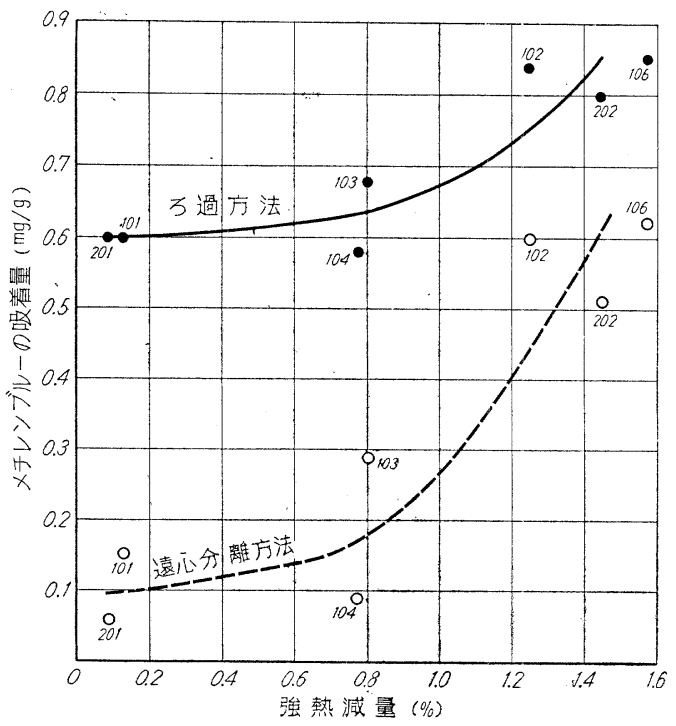

注 : 数字はフライアッンュの番号を示す。 
表-8 フライアッシュの品質試験成績総括表（第 1 回試験）その 1

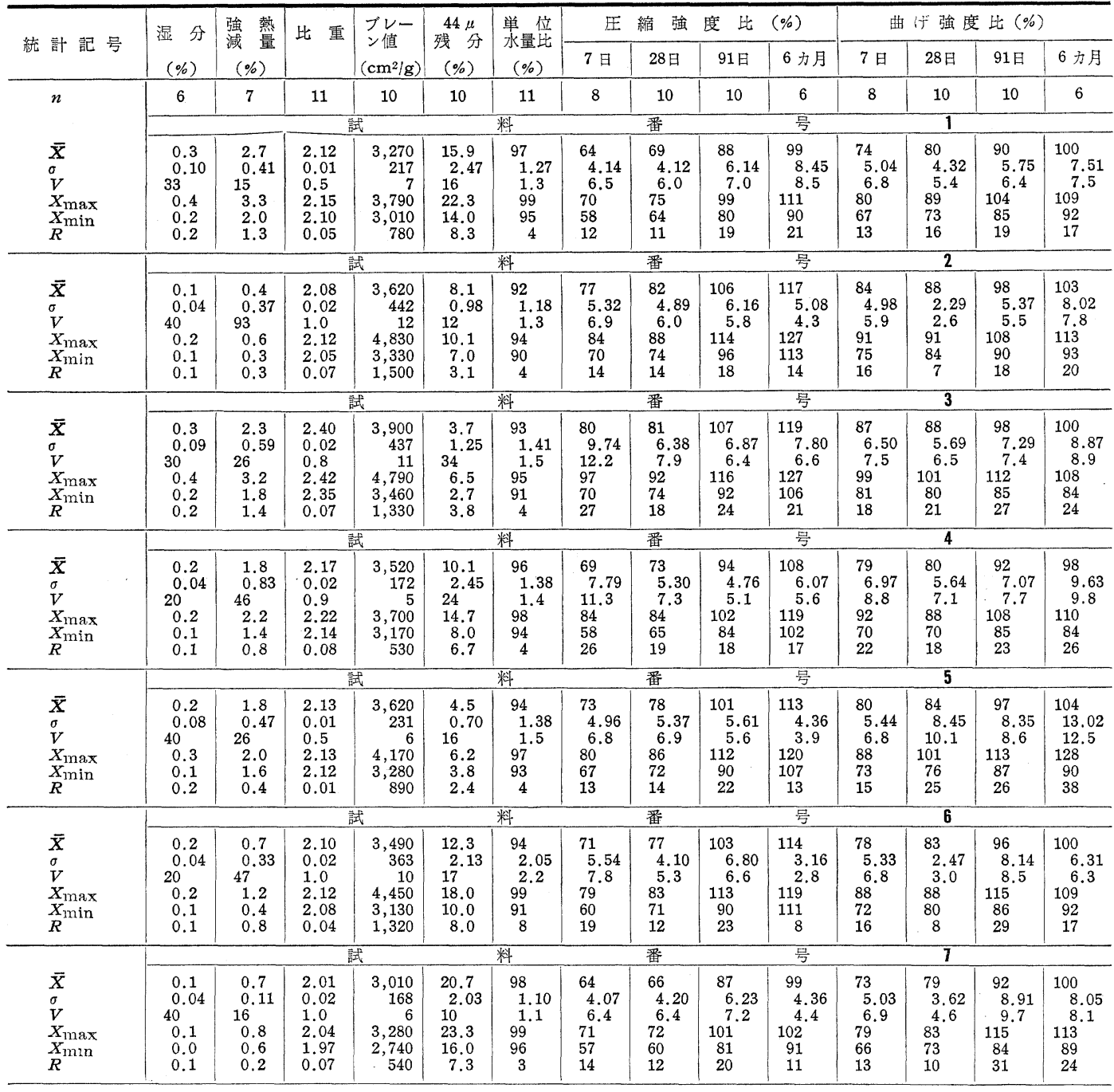

表一9 フライアッシュの品質試験成績総括表（第 1 回試験）その 2

\begin{tabular}{|c|c|c|c|c|c|c|c|c|c|c|c|c|c|c|}
\hline \multirow{2}{*}{ 試 料 番 号 } & \multirow{2}{*}{$\begin{array}{c}\text { 湿 分 } \\
(\%)\end{array}$} & \multirow{2}{*}{$\begin{array}{c}\text { 強 熱 } \\
\text { 減 量 } \\
(\%)\end{array}$} & \multirow[t]{2}{*}{ 比重 } & \multirow{2}{*}{$\left|\begin{array}{l}\text { プレー } \\
\text { ン值 } \\
\left(\mathrm{cm}^{2} / \mathrm{g}\right)\end{array}\right|$} & \multirow{2}{*}{$\begin{array}{c}44 \mu \\
\text { 残 分 } \\
(\%)\end{array}$} & \multirow{2}{*}{$\begin{array}{c}\text { 単位 } \\
\text { 水量比 } \\
(\%)\end{array}$} & \multicolumn{4}{|c|}{ 圧 縮 強 度 比 (\%) } & \multicolumn{4}{|c|}{ 曲 } \\
\hline & & & & & & & 7 日 & 28日 & 91日 & 6 力月 & 7 日 & 28日 & 91日 & 6 力月 \\
\hline & \multicolumn{6}{|c|}{ 平 } & \multicolumn{8}{|c|}{ 值 $(\overline{\bar{X}})$} \\
\hline $\begin{array}{l}1 \\
2 \\
3 \\
4 \\
5 \\
6 \\
7\end{array}$ & $\begin{array}{l}0.3 \\
0.1 \\
0.3 \\
0.2 \\
0.2 \\
0.2 \\
0.1\end{array}$ & $\begin{array}{l}2.7 \\
0.4 \\
2.3 \\
1.8 \\
1.8 \\
0.7 \\
0.7\end{array}$ & $\begin{array}{l}2.12 \\
2.08 \\
2.40 \\
2.17 \\
2.13 \\
2.10 \\
2.01\end{array}$ & $\begin{array}{l}3,270 \\
3,620 \\
3,900 \\
3,520 \\
3,620 \\
3,490 \\
3,010\end{array}$ & $\begin{array}{r}15.9 \\
8.1 \\
3.7 \\
10.1 \\
4.5 \\
12.3 \\
20.7\end{array}$ & $\begin{array}{l}97 \\
92 \\
93 \\
96 \\
94 \\
94 \\
98\end{array}$ & $\begin{array}{l}64 \\
77 \\
80 \\
69 \\
73 \\
71 \\
64\end{array}$ & $\begin{array}{l}69 \\
82 \\
81 \\
73 \\
78 \\
77 \\
66\end{array}$ & $\begin{array}{r}88 \\
106 \\
107 \\
94 \\
101 \\
103 \\
87\end{array}$ & $\begin{array}{r}99 \\
117 \\
119 \\
108 \\
113 \\
114 \\
99\end{array}$ & $\begin{array}{l}74 \\
84 \\
87 \\
79 \\
80 \\
78 \\
73\end{array}$ & $\begin{array}{l}80 \\
88 \\
88 \\
80 \\
84 \\
83 \\
79\end{array}$ & $\begin{array}{l}90 \\
98 \\
98 \\
92 \\
97 \\
96 \\
92\end{array}$ & $\begin{array}{r}100 \\
103 \\
100 \\
98 \\
104 \\
100 \\
100\end{array}$ \\
\hline & \multicolumn{6}{|c|}{ 標 } & \multicolumn{8}{|c|}{ 差 $(\sigma)$} \\
\hline $\begin{array}{l}1 \\
2 \\
3 \\
4 \\
5 \\
6 \\
7\end{array}$ & $\begin{array}{l}0.10 \\
0.04 \\
0.09 \\
0.04 \\
0.08 \\
0.04 \\
0.04\end{array}$ & $\begin{array}{l}0.41 \\
0.37 \\
0.59 \\
0.83 \\
0.47 \\
0.33 \\
0.11\end{array}$ & $\begin{array}{l}0.01 \\
0.02 \\
0.02 \\
0.02 \\
0.01 \\
0.02 \\
0.02\end{array}$ & $\begin{array}{l}217 \\
442 \\
437 \\
172 \\
231 \\
363 \\
168\end{array}$ & $\begin{array}{l}2.47 \\
0.98 \\
1.25 \\
2.45 \\
0.70 \\
2.13 \\
2.03\end{array}$ & $\begin{array}{l}1.27 \\
1.18 \\
1.41 \\
1.38 \\
1.38 \\
2.05 \\
1.10\end{array}$ & $\begin{array}{l}4.14 \\
5.32 \\
9.74 \\
7.79 \\
4.96 \\
5.54 \\
4.07\end{array}$ & $\begin{array}{l}4.12 \\
4.89 \\
6.38 \\
5.30 \\
5.37 \\
4.10 \\
4.20\end{array}$ & $\begin{array}{l}6.14 \\
6.16 \\
6.87 \\
4.76 \\
5.61 \\
6.80 \\
6.23\end{array}$ & $\begin{array}{l}8.45 \\
5.08 \\
7.80 \\
6.07 \\
4.36 \\
3.16 \\
4.36\end{array}$ & $\begin{array}{l}5.04 \\
4.98 \\
6.50 \\
6.97 \\
5.44 \\
5.33 \\
5.03\end{array}$ & $\begin{array}{l}4.32 \\
2.29 \\
5.69 \\
5.64 \\
8.45 \\
2.47 \\
3.62\end{array}$ & $\begin{array}{l}5.75 \\
5.37 \\
7.29 \\
7.07 \\
8.35 \\
8.14 \\
8.91\end{array}$ & $\begin{array}{r}7.51 \\
8.02 \\
8.87 \\
9.63 \\
13.02 \\
6.31 \\
8.05\end{array}$ \\
\hline & \multicolumn{6}{|c|}{ 変 } & \multicolumn{8}{|c|}{ 数 $(V)$} \\
\hline $\begin{array}{l}1 \\
2 \\
3 \\
4 \\
5 \\
6 \\
7\end{array}$ & $\begin{array}{l}33 \\
40 \\
30 \\
20 \\
40 \\
20 \\
40\end{array}$ & $\begin{array}{l}15 \\
93 \\
26 \\
46 \\
26 \\
47 \\
16\end{array}$ & $\begin{array}{l}0.5 \\
1.0 \\
0.8 \\
0.9 \\
0.5 \\
1.0 \\
1.0\end{array}$ & $\begin{array}{r}7 \\
12 \\
11 \\
5 \\
6 \\
10 \\
6\end{array}$ & $\begin{array}{l}16 \\
12 \\
34 \\
24 \\
16 \\
17 \\
10\end{array}$ & $\begin{array}{l}1.3 \\
1.3 \\
1.5 \\
1.4 \\
1.5 \\
2.2 \\
1.1\end{array}$ & $\begin{array}{r}6.5 \\
6.9 \\
12.2 \\
11.3 \\
6.8 \\
7.8 \\
6.4\end{array}$ & $\begin{array}{l}6.0 \\
6.0 \\
7.9 \\
7.3 \\
6.9 \\
5.3 \\
6.4\end{array}$ & $\begin{array}{l}7.0 \\
5.8 \\
6.4 \\
5.1 \\
5.6 \\
6.6 \\
7.2\end{array}$ & $\begin{array}{l}8.5 \\
4.3 \\
6.6 \\
5.6 \\
3.9 \\
2.8 \\
4.4\end{array}$ & $\begin{array}{l}6.8 \\
5.9 \\
7.5 \\
8.8 \\
6.8 \\
6.8 \\
6.9\end{array}$ & $\begin{array}{r}5.4 \\
2.6 \\
6.5 \\
7.1 \\
10.1 \\
3.0 \\
4.6\end{array}$ & $\begin{array}{l}6.4 \\
5.5 \\
7.4 \\
7.7 \\
8.6 \\
8.5 \\
9.7\end{array}$ & $\begin{array}{r}7.5 \\
7.8 \\
8.9 \\
9.8 \\
12.5 \\
6.3 \\
8.1\end{array}$ \\
\hline
\end{tabular}




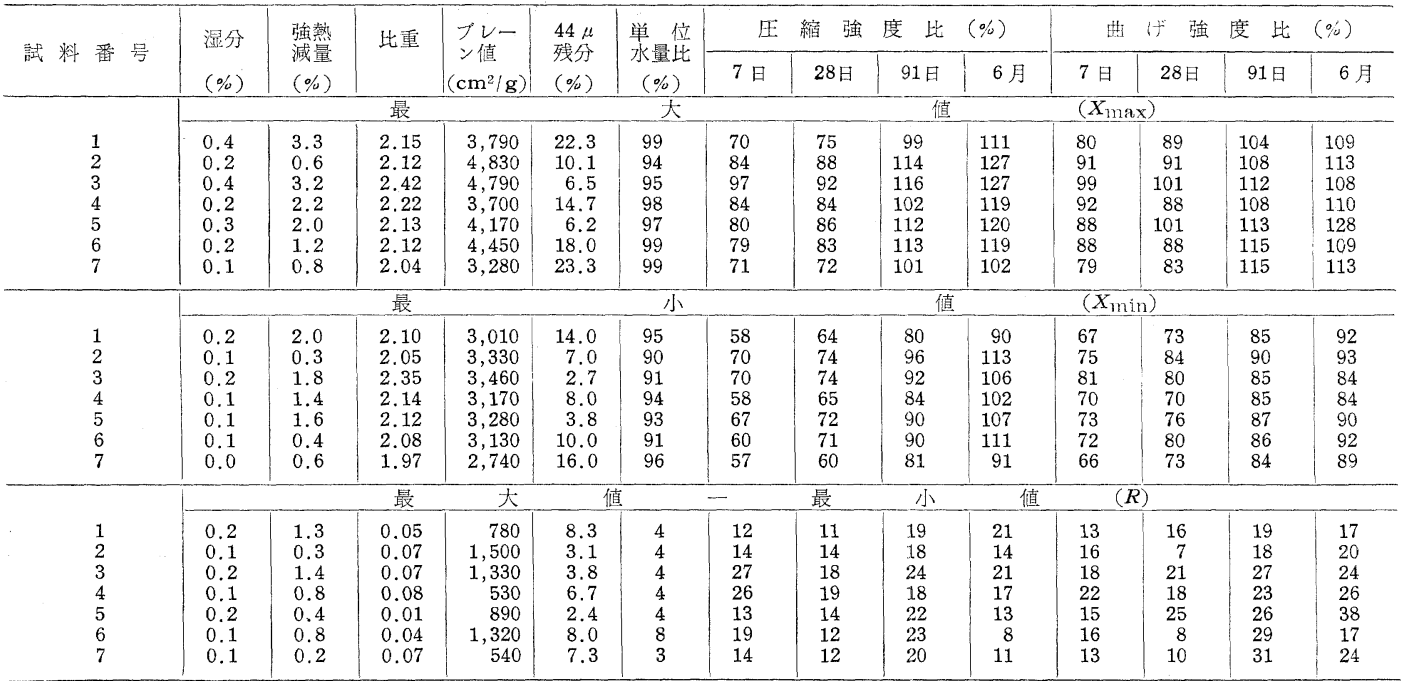

表一10 フライ アッシュの品質試験成績総括表（第 1 回試験）その 3

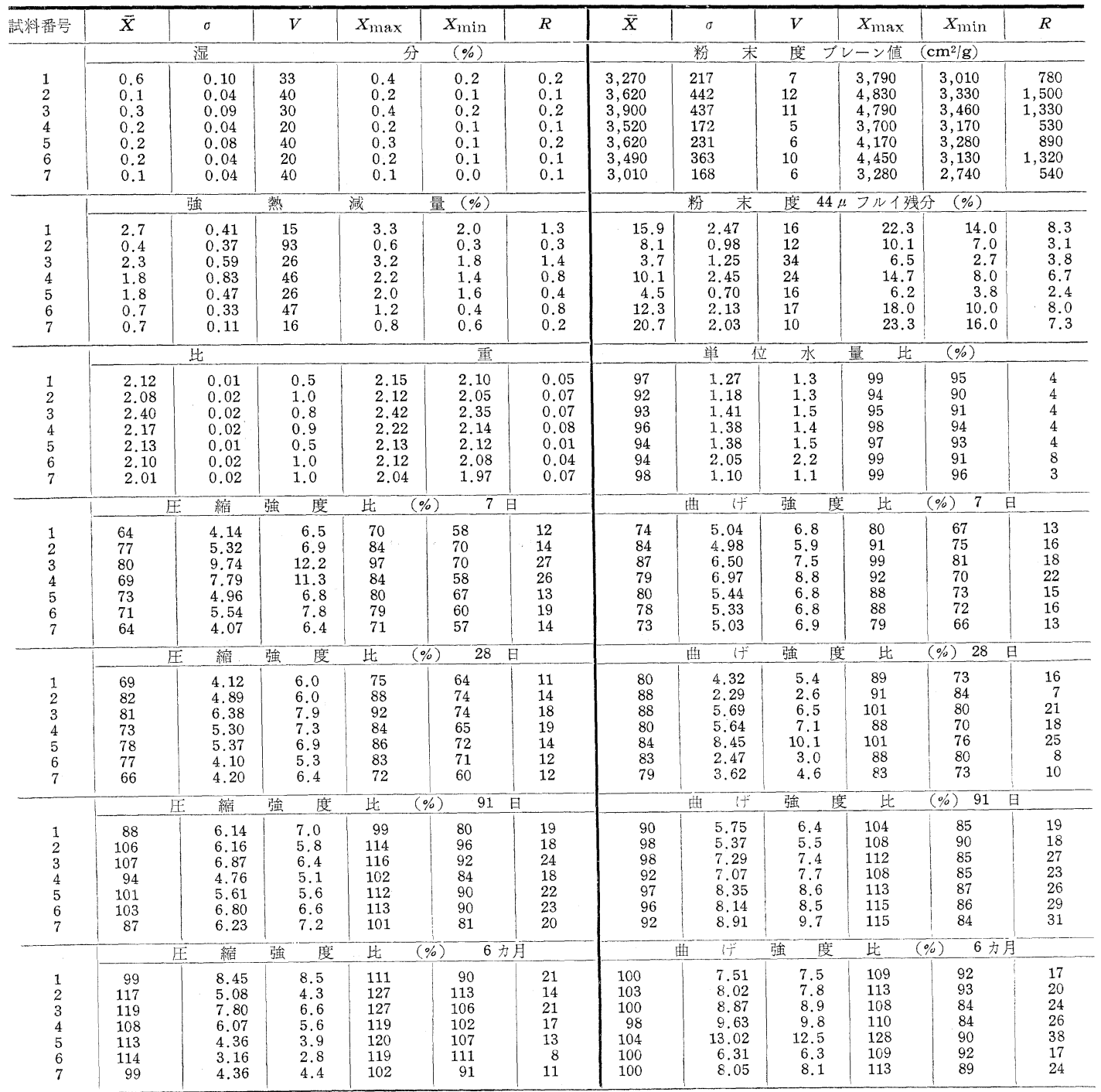


表一11 試験の平均値から求めた, フライ アッシュの品質の相違（第 1 回試験）

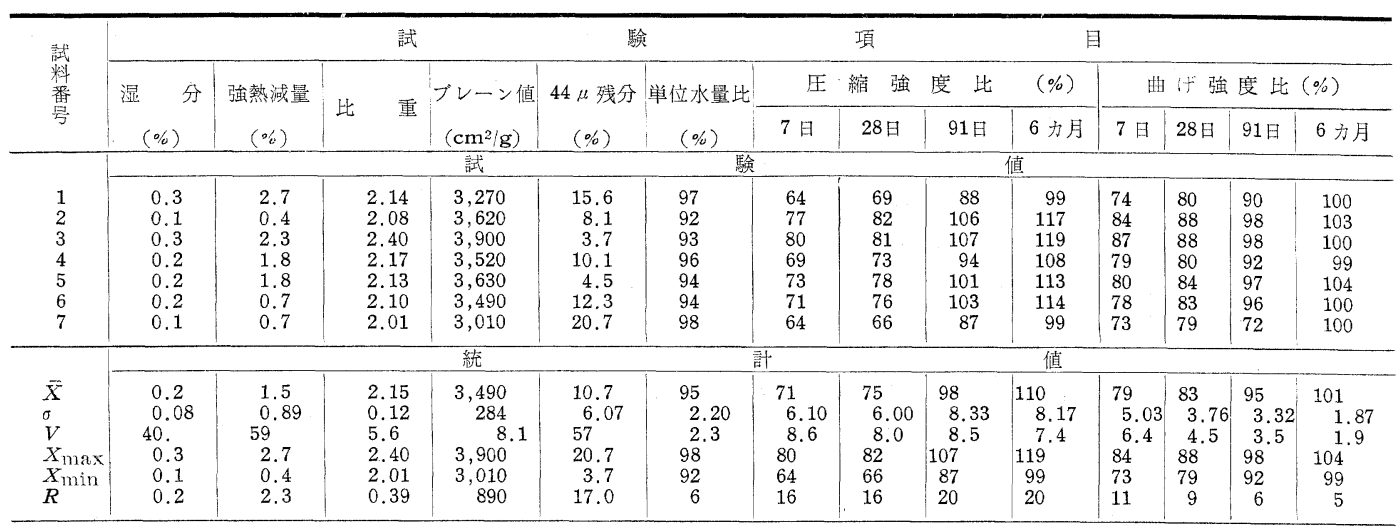

\section{第 5 章 各種フライアッシュの品質の均一性に関する調査}

\section{1. 調查の方法}

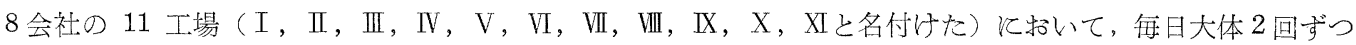
1 力月にわたつて連続して約 60 試料を採取し, 湿分, 強熱減量, 比重, 粉末度(ブレーン, $44 \mu$ ふるいおよび $88 \mu$ ふるい), 単位水量比, メチレンブルーの吸着量, 等をJIS そよつて試験し, フライアッシュの品質の変動 を調査した。試料を採取した位置は，袋詰めを行う場所であり，各試料の試験はとれぞれの工場で行つた。

調查は昭和 33 年 8 月（豊水期）からと昭和 33 年 12 月（渴水期）からとの 2 期に轻いて行つたのである。

\section{2. 調査の結果}

調査の結果は 表一12 15 扒よび 図一16，17，18 亿示すごとくであつて，表一13 恃試験項目ごとの各工場 の変動状況を総括して比較したものである。表一12 15 拈よび 図一16〜18 から次のことが怣められる。

（1）工場によつて相当な差はあるが，ほとんぞ全部の工場が豊水期にも渴水期にるJIS の均一性の規格に 合格している。これは, 各工場ともに, 生産されるフライアッシュのうち規格に合格する部分だけ走商品として 取报つていることを示するのである。

な拎，一般とブレーン值の変動は大きく変動の限界（最大值一最小值） は $250 \sim 1,150 \mathrm{~cm}^{2} / \mathrm{g}$ であるが，単位 水量此の変動忯さく大部分のものの変動の限界は 1 6\% となつている。従つて JIS の均一性の規格值につ いては特に一層の研究が必要であると思われる。

また II, IV , V, VI, VII, VII, IX の 7 工場と怙いてはブレーン值の変動と $44 \mu$ ふるい残分の変動とがよく類似し ている(図一3 学照)。

（2）フライアッシュの品質の変動は渴水期よりる豊水期に捻いて，いちじるしいと思われたが，図一16 お よび 図一17 によれば, これが認められるのはV㧍よびVIの工場だけである。

（3）各工場の試験值を通覧し，試験值だけから判定すれば，品質の変動はVIII 呿よびXI の 2 工場では少な く，Vの工場ではいちじるしくなつている。これはフライアッシュの生産設備の相違のみならず，微粉炭の品 質, 工場 (火力発電所) の運転状況, 試料の数, 試験担当者乞の他, の相違にるよると思われる。

フライアッシュの品質の均一性が，工場（火力発電所）の運転状況拈よび生産設備によつていちじるしく相違 することは論をまたない。調査した 11 工場の中の数工場は, 旧式な設備を持つた工場であつた。このような旧 式発電所は能率が悪いので, 火力発電の主力は逐次新鋭火力発電所に移りつつある。この調査のあとにも現在 (昭和 35 年 1 月) までに 2 3 の新鋭火力発電所が操業を開始し, 負荷率 $90 \%$ 程度に所謂 常時運転を行つて いる。新鋭火力発電所で生産されているフライアッシュの均一性は旧式発電所飞招けるもの上りる, ある程度ま で向上していると思わ秃る。 
表一12 各工場におけるフライ アッシュの品質の変動（その 1）

\begin{tabular}{|c|c|c|c|c|c|c|c|c|c|c|c|c|c|c|}
\hline \multirow{2}{*}{$\begin{array}{l}\text { 統 訫 值 } \\
\text { 項 目 }\end{array}$} & \multicolumn{3}{|c|}{ 豊 } & 水 & \multicolumn{3}{|c|}{ 期 } & \multicolumn{3}{|c|}{ 渴 } & 水 & \multicolumn{3}{|c|}{ 期 } \\
\hline & 調査工場 & $\begin{array}{c}\text { 湿 }(\%) \\
\text { 分 }\end{array}$ & \begin{tabular}{|c|}
$($ 強熱減量 \\
\end{tabular} & 比 重 & $\left|\begin{array}{l}\text { プ } \\
\text { ン值 } \\
\left(\mathrm{cm}^{2} / \mathrm{g}\right)\end{array}\right|$ & $\begin{array}{c}44 \mu \text { 残 } \\
\text { 分 }(\%)\end{array}$ & $\begin{array}{c}\text { 筆 位 } \\
\text { 水量比 } \\
(\%)\end{array}$ & 調查工場 & 湿 $(\%)$ & $\begin{array}{c}\text { 強熱滅量 } \\
(\%)\end{array} \mid$ & 比重 & $\begin{array}{l}\text { ブレー } \\
\text { ン倎 } \\
\left(\mathrm{cm}^{2} / \mathrm{g}\right)\end{array}$ & $\begin{array}{l}44 \mu \text { 残 } \\
\text { 分 }(\%)\end{array}$ & $\begin{array}{c}\text { 童 位 } \\
\text { 水量比 } \\
(\%)\end{array}$ \\
\hline $\begin{array}{l}n \\
\bar{X} \\
\sigma \\
V \\
X_{\max } \\
X_{\min } \\
R\end{array}$ & III & & $\begin{array}{c}59 \\
0.1 \\
0.082 \\
82 \\
0.6 \\
0.1 \\
0.5\end{array}$ & $\begin{array}{c}59 \\
2.13 \\
0.036 \\
1.7 \\
2.23 \\
2.07 \\
0.16\end{array}$ & $\begin{array}{c}59 \\
3,060 \\
116 \\
3.8 \\
3,250 \\
2,680 \\
570\end{array}$ & $\begin{array}{c}59 \\
4.7 \\
1.58 \\
34 \\
9.9 \\
2.0 \\
7.9\end{array}$ & & I & $\begin{array}{c}40 \\
0.1 \\
0.046 \\
46 \\
0.1 \\
0.0 \\
0.1\end{array}$ & $\begin{array}{c}40 \\
1.2 \\
0.135 \\
11 \\
1.5 \\
0.9 \\
0.6\end{array}$ & $\begin{array}{l}40 \\
2.18 \\
0.016 \\
0.7 \\
2.22 \\
2.15 \\
0.07\end{array}$ & $\begin{array}{c}40 \\
3,470 \\
162 \\
4.7 \\
3,780 \\
3,220 \\
560\end{array}$ & $\begin{array}{c}40 \\
10.6 \\
1.47 \\
14 \\
13.7 \\
8.2 \\
5.5\end{array}$ & $\begin{array}{l}40 \\
96 \\
0.43 \\
0.4 \\
96 \\
94 \\
2\end{array}$ \\
\hline $\begin{array}{l}n \\
\bar{X} \\
\sigma \\
V \\
X_{\max } \\
X_{\min } \\
R\end{array}$ & IIII & $\begin{array}{c}60 \\
0.2 \\
0.085 \\
42 \\
0.5 \\
0.1 \\
0.4\end{array}$ & $\begin{array}{c}60 \\
0.8 \\
0.234 \\
29 \\
1.6 \\
0.4 \\
1.2\end{array}$ & \begin{tabular}{l|}
7 \\
2.22 \\
0.058 \\
2.6 \\
2.23 \\
2.19 \\
0.04
\end{tabular} & $\begin{array}{c}60 \\
3,430 \\
200 \\
5.8 \\
3,880 \\
2,980 \\
900\end{array}$ & $\begin{array}{c}60 \\
5.9 \\
1.19 \\
20 \\
9.8 \\
3.6 \\
6.2\end{array}$ & $\begin{array}{l}12 \\
94 \\
1.31 \\
1.4 \\
96 \\
92 \\
4\end{array}$ & II & \begin{tabular}{c|}
51 \\
0.1 \\
0.042 \\
42 \\
0.2 \\
0.0 \\
0.2
\end{tabular} & $\begin{array}{c}51 \\
0.2 \\
0.068 \\
34 \\
0.3 \\
0.1 \\
0.2\end{array}$ & $\begin{array}{c}51 \\
2.13 \\
0.036 \\
1.7 \\
2.18 \\
2.03 \\
0.15\end{array}$ & $\begin{array}{c}51 \\
2,980 \\
211 \\
7.1 \\
3,300 \\
2,390 \\
910\end{array}$ & \begin{tabular}{c|}
51 \\
5.4 \\
3.22 \\
60 \\
13.7 \\
1.0 \\
12.7
\end{tabular} & $\begin{array}{l}51 \\
88 \\
2.51 \\
2.9 \\
94 \\
84 \\
10\end{array}$ \\
\hline $\begin{array}{l}n \\
\bar{X} \\
\sigma \\
V \\
X_{\max } \\
X_{\min } \\
R\end{array}$ & N & $\begin{array}{c}60 \\
0.2 \\
0.068 \\
34 \\
0.3 \\
0.1 \\
0.2\end{array}$ & \begin{tabular}{|c|}
60 \\
1.4 \\
0.381 \\
27 \\
2.2 \\
0.6 \\
1.6
\end{tabular} & \begin{tabular}{l|}
7 \\
2.18 \\
0.016 \\
0.7 \\
2.20 \\
2.16 \\
0.04
\end{tabular} & $\begin{array}{c}60 \\
3,490 \\
219 \\
6.3 \\
3,940 \\
3,040 \\
900\end{array}$ & $\begin{array}{c}60 \\
6.8 \\
3.29 \\
48 \\
13.2 \\
4.0 \\
9.2\end{array}$ & $\begin{array}{l}12 \\
96 \\
0.55 \\
0.6 \\
96 \\
95 \\
1\end{array}$ & III & $\begin{array}{c}60 \\
0.1 \\
0.063 \\
63 \\
0.3 \\
0.1 \\
0.2\end{array}$ & $\begin{array}{c}60 \\
0.9 \\
0.179 \\
20 \\
1.3 \\
0.6 \\
0.7\end{array}$ & $\begin{array}{c}60 \\
2.22 \\
0.011 \\
0.5 \\
2.24 \\
2.19 \\
0.05\end{array}$ & $\begin{array}{c}60 \\
3,440 \\
105 \\
3.1 \\
3,700 \\
3,170 \\
530\end{array}$ & $\begin{array}{c}60 \\
6.8 \\
3.10 \\
46 \\
9.0 \\
6.0 \\
3.0 \\
\end{array}$ & $\begin{array}{l}60 \\
90 \\
2.07 \\
2.3 \\
93 \\
86 \\
7\end{array}$ \\
\hline $\begin{array}{l}n \\
\bar{X} \\
\sigma \\
V \\
X_{\max } \\
X_{\min } \\
R\end{array}$ & V & $\begin{array}{c}11 \\
0.1 \\
0.050 \\
50 \\
0.2 \\
0.1 \\
0.1\end{array}$ & \begin{tabular}{|c|}
11 \\
1.7 \\
0.493 \\
29 \\
3.0 \\
1.3 \\
1.7
\end{tabular} & $\begin{array}{c}11 \\
2.13 \\
0.014 \\
0.7 \\
2.16 \\
2.11 \\
0.05\end{array}$ & $\begin{array}{c}11 \\
3,260 \\
370 \\
11.4 \\
3,960 \\
2,790 \\
1,170\end{array}$ & $\begin{array}{l}11 \\
6.1 \\
1.88 \\
31 \\
10.6 \\
3.0 \\
7.6\end{array}$ & & IV & $\begin{array}{c}60 \\
0.3 \\
0.070 \\
23 \\
0.5 \\
0.1 \\
0.4\end{array}$ & $\begin{array}{c}60 \\
1.1 \\
0.386 \\
35 \\
2.0 \\
0.7 \\
1.3\end{array}$ & $\begin{array}{l}60 \\
2.18 \\
0.008 \\
0.4 \\
2.20 \\
2.16 \\
0.04\end{array}$ & $\begin{array}{c}60 \\
3,530 \\
193 \\
5.5 \\
3,960 \\
3,170 \\
790\end{array}$ & $\begin{array}{c}60 \\
8.3 \\
1.37 \\
17 \\
12.0 \\
5.0 \\
7.0\end{array}$ & $\begin{array}{l}60 \\
93 \\
1.72 \\
1.9 \\
96 \\
88 \\
8\end{array}$ \\
\hline $\begin{array}{l}n \\
\bar{X} \\
\sigma \\
V \\
X_{\max } \\
X_{\min } \\
R \\
\end{array}$ & VI & $\begin{array}{c}60 \\
0.2 \\
0.067 \\
34 \\
0.4 \\
0.1 \\
0.3\end{array}$ & $\mid \begin{array}{c}60 \\
0.6 \\
0.133 \\
22 \\
0.9 \\
0.4 \\
0.5\end{array}$ & $\begin{array}{c}60 \\
2.24 \\
0.019 \\
0.8 \\
2.28 \\
2.18 \\
0.10\end{array}$ & $\begin{array}{c}60 \\
3,360 \\
265 \\
7.9 \\
3,870 \\
2,950 \\
920\end{array}$ & $\begin{array}{l}60 \\
10.5 \\
2.75 \\
26 \\
18.0 \\
4.6 \\
13.4\end{array}$ & $\begin{array}{l}60 \\
93 \\
1.69 \\
1.8 \\
96 \\
91 \\
5\end{array}$ & V & $\begin{array}{c}57 \\
0.2 \\
0.054 \\
27 \\
0.3 \\
0.1 \\
0.2\end{array}$ & $\begin{array}{c}57 \\
1.6 \\
0.227 \\
14 \\
2.1 \\
1.2 \\
0.9\end{array}$ & $\begin{array}{c}57 \\
2.15 \\
0.016 \\
0.7 \\
2.20 \\
2.12 \\
0.08\end{array}$ & $\begin{array}{c}57 \\
3,250 \\
180 \\
5.5 \\
3,820 \\
2,940 \\
880\end{array}$ & $\begin{array}{l}57 \\
5.9 \\
1.67 \\
28 \\
10.1 \\
2.6 \\
7.5\end{array}$ & \\
\hline $\begin{array}{l}n \\
\ddot{X} \\
\sigma \\
V \\
X_{\max } \\
X_{\min } \\
R\end{array}$ & VII & $\begin{array}{c}16 \\
0.1 \\
0.045 \\
45 \\
0.1 \\
0.0 \\
0.1\end{array}$ & $\begin{array}{c}16 \\
0.9 \\
0.111 \\
12 \\
1.1 \\
0.7 \\
0.4\end{array}$ & $\begin{array}{c}16 \\
2.14 \\
0.032 \\
1.5 \\
2.19 \\
2.10 \\
0.09\end{array}$ & $\begin{array}{c}16 \\
3,290 \\
345 \\
10.5 \\
3,870 \\
2,750 \\
1,120\end{array}$ & $\begin{array}{l}16 \\
2.8 \\
1.24 \\
44 \\
5.6 \\
1.5 \\
4.1\end{array}$ & & VI & $\begin{array}{c}62 \\
0.1 \\
0.050 \\
50 \\
0.2 \\
0.1 \\
0.1\end{array}$ & $\begin{array}{c}62 \\
0.6 \\
0.151 \\
25 \\
1.1 \\
0.4 \\
0.7\end{array}$ & $\begin{array}{c}62 \\
2.22 \\
0.022 \\
1.0 \\
2.26 \\
2.17 \\
0.09\end{array}$ & $\begin{array}{c}62 \\
3,240 \\
161 \\
5.0 \\
3,760 \\
3,010 \\
750\end{array}$ & $\begin{array}{c}62 \\
15.1 \\
1.74 \\
12 \\
19.1 \\
10.9 \\
8.2\end{array}$ & $\begin{array}{l}62 \\
93 \\
0.69 \\
0.7 \\
94 \\
91 \\
3\end{array}$ \\
\hline $\begin{array}{l}n \\
\bar{X} \\
\sigma \\
V \\
X_{\max } \\
X_{\min } \\
R\end{array}$ & VIII & $\begin{array}{c}60 \\
0.2 \\
0.063 \\
32 \\
0.3 \\
0.1 \\
0.2\end{array}$ & \begin{tabular}{|c|}
60 \\
1.7 \\
0.209 \\
12 \\
2.0 \\
1.4 \\
0.6
\end{tabular} & $\begin{array}{l}60 \\
2.14 \\
0.008 \\
0.4 \\
2.16 \\
2.13 \\
0.03\end{array}$ & \begin{tabular}{|c|}
60 \\
3,170 \\
114 \\
3.6 \\
3,430 \\
3,000 \\
430
\end{tabular} & $\begin{array}{l}60 \\
15.8 \\
1.98 \\
12 \\
19.1 \\
11.9 \\
7.2\end{array}$ & $\begin{array}{l}60 \\
95 \\
0.64 \\
0.7 \\
96 \\
94 \\
2\end{array}$ & VII & \begin{tabular}{c|}
60 \\
0.1 \\
0.044 \\
44 \\
0.2 \\
0.0 \\
0.2
\end{tabular} & $\begin{array}{c}60 \\
0.1 \\
0.102 \\
102 \\
1.3 \\
0.8 \\
0.5\end{array}$ & $\begin{array}{l}60 \\
2.14 \\
0.024 \\
1.1 \\
2.18 \\
2.05 \\
0.13\end{array}$ & $\begin{array}{c}60 \\
3,000 \\
192 \\
6.4 \\
3,400 \\
2,400 \\
1,000\end{array}$ & $\begin{array}{l}60 \\
7.9 \\
1.91 \\
24 \\
13.5 \\
4.5 \\
9.0\end{array}$ & \\
\hline $\begin{array}{l}n \\
\bar{X} \\
\sigma \\
V \\
X_{\max } \\
X_{\min } \\
R\end{array}$ & IX & $\begin{array}{c}60 \\
0.2 \\
0.036 \\
18 \\
0.3 \\
0.1 \\
0.2\end{array}$ & $\mid \begin{array}{c}60 \\
0.5 \\
0.236 \\
47 \\
1.4 \\
0.2 \\
1.2\end{array}$ & & $\begin{array}{c}60 \\
3,280 \\
154 \\
4.7 \\
3,640 \\
3,010 \\
630\end{array}$ & $\begin{array}{l}60 \\
13.2 \\
2.51 \\
19 \\
18.1 \\
7.1 \\
11.0\end{array}$ & $\begin{array}{l}60 \\
94 \\
1.50 \\
1.6 \\
97 \\
91 \\
6\end{array}$ & VIII & $\begin{array}{c}30 \\
0.2 \\
0.048 \\
24 \\
0.3 \\
.0 .1 \\
0.2\end{array}$ & \begin{tabular}{|c|}
30 \\
1.3 \\
0.142 \\
11 \\
1.7 \\
1.1 \\
0.6
\end{tabular} & \begin{tabular}{c|}
30 \\
2.15 \\
0.007 \\
0.3 \\
2.17 \\
2.15 \\
0.02
\end{tabular} & $\begin{array}{r}30 \\
3,100 \\
72 \\
2.3 \\
3,260 \\
3,020 \\
240\end{array}$ & $\begin{array}{l}30 \\
14.1 \\
1.42 \\
10 \\
17.8 \\
11.0 \\
6.8\end{array}$ & $\begin{array}{l}30 \\
94 \\
0.50 \\
0.5 \\
95 \\
94 \\
1\end{array}$ \\
\hline $\begin{array}{l}n \\
\bar{X} \\
\sigma \\
V \\
X_{\max } \\
X_{\min } \\
R\end{array}$ & $\mathrm{X}$ & $\begin{array}{c}59 \\
0.2 \\
0.161 \\
81 \\
0.6 \\
0.0 \\
0.6\end{array}$ & $\mid$\begin{tabular}{c|}
59 \\
1.1 \\
0.354 \\
32 \\
2.0 \\
0.4 \\
1.6
\end{tabular} & $\begin{array}{c}11 \\
2.32 \\
0.036 \\
1.6 \\
2.39 \\
2.28 \\
0.11\end{array}$ & $\begin{array}{c}59 \\
3,430 \\
196 \\
5.7 \\
3,770 \\
2,970 \\
800\end{array}$ & $\begin{array}{c}59 \\
2.5 \\
0.95 \\
38 \\
7.0 \\
1.0 \\
6.0\end{array}$ & $\begin{array}{l}59 \\
94 \\
0.47 \\
0.5 \\
95 \\
94 \\
1\end{array}$ & IX & \begin{tabular}{c|}
51 \\
0.2 \\
0.039 \\
20 \\
0.3 \\
0.1 \\
0.2
\end{tabular} & \begin{tabular}{|c|}
51 \\
0.5 \\
0.158 \\
32 \\
1.0 \\
0.3 \\
0.7
\end{tabular} & & $\begin{array}{c}51 \\
3,320 \\
162 \\
4.9 \\
3,560 \\
3,040 \\
520\end{array}$ & $\begin{array}{l}51 \\
16.8 \\
3.10 \\
18 \\
23.9 \\
10.9 \\
13.0\end{array}$ & $\begin{array}{l}51 \\
93 \\
1.64 \\
1.8 \\
96 \\
90 \\
6\end{array}$ \\
\hline $\begin{array}{l}n \\
\bar{X} \\
\sigma \\
V \\
X_{\max } \\
X_{\min } \\
R\end{array}$ & $\mathrm{XI}$ & $\begin{array}{c}60 \\
0.1 \\
0.025 \\
25 \\
0.2 \\
0.1 \\
0.1\end{array}$ & \begin{tabular}{c|}
60 \\
0.9 \\
0.133 \\
15 \\
1.2 \\
0.6 \\
0.6
\end{tabular} & $\begin{array}{l}40 \\
2.03 \\
0.014 \\
0.7 \\
2.06 \\
2.00 \\
0.06\end{array}$ & $\mid \begin{array}{c}60 \\
3,170 \\
95 \\
3.0 \\
3,350 \\
3,000 \\
350\end{array}$ & $\begin{array}{l}16 \\
19.0 \\
1.55 \\
8 \\
23.5 \\
17.0 \\
6.5\end{array}$ & $\begin{array}{c}60 \\
98 \\
0.87 \\
0.9 \\
100 \\
97 \\
3\end{array}$ & XI & $\begin{array}{c}64 \\
0.1 \\
0.018 \\
18 \\
0.2 \\
0.1 \\
0.1\end{array}$ & \begin{tabular}{|c|}
64 \\
1.0 \\
0.165 \\
17 \\
1.3 \\
0.7 \\
0.6
\end{tabular} & \begin{tabular}{l|}
35 \\
2.03 \\
0.013 \\
0.6 \\
2.05 \\
2.01 \\
0.04
\end{tabular} & $\begin{array}{c}64 \\
3,180 \\
112 \\
3.5 \\
3,500 \\
3,000 \\
500\end{array}$ & $\begin{array}{l}38 \\
18.8 \\
2.61 \\
14 \\
26.0 \\
15.5 \\
10.5\end{array}$ & $\begin{array}{c}64 \\
98 \\
0.68 \\
0.7 \\
100 \\
97 \\
3\end{array}$ \\
\hline
\end{tabular}


表一13 各工場におけるフライアッシュの品質の変動（その2）

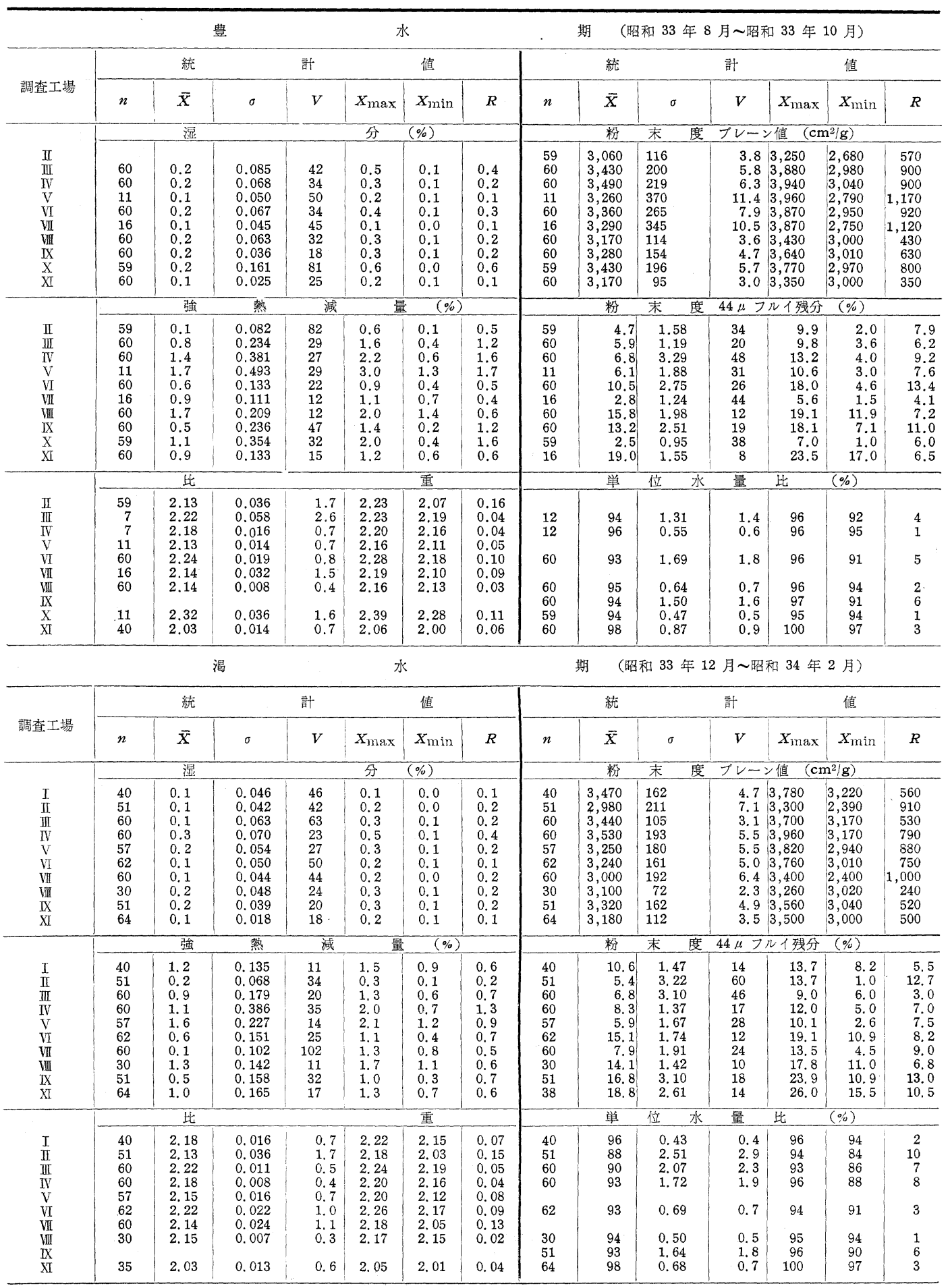



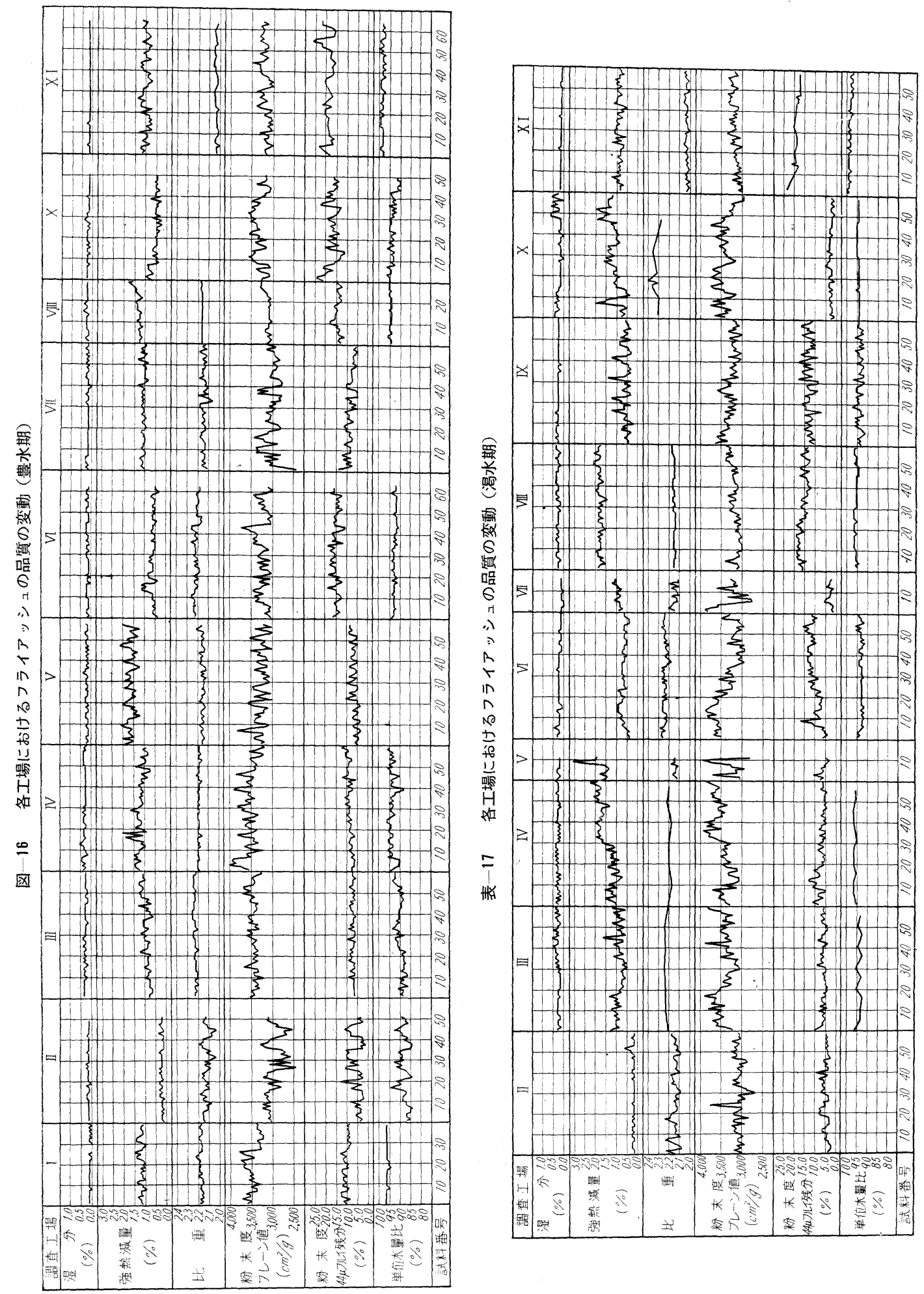


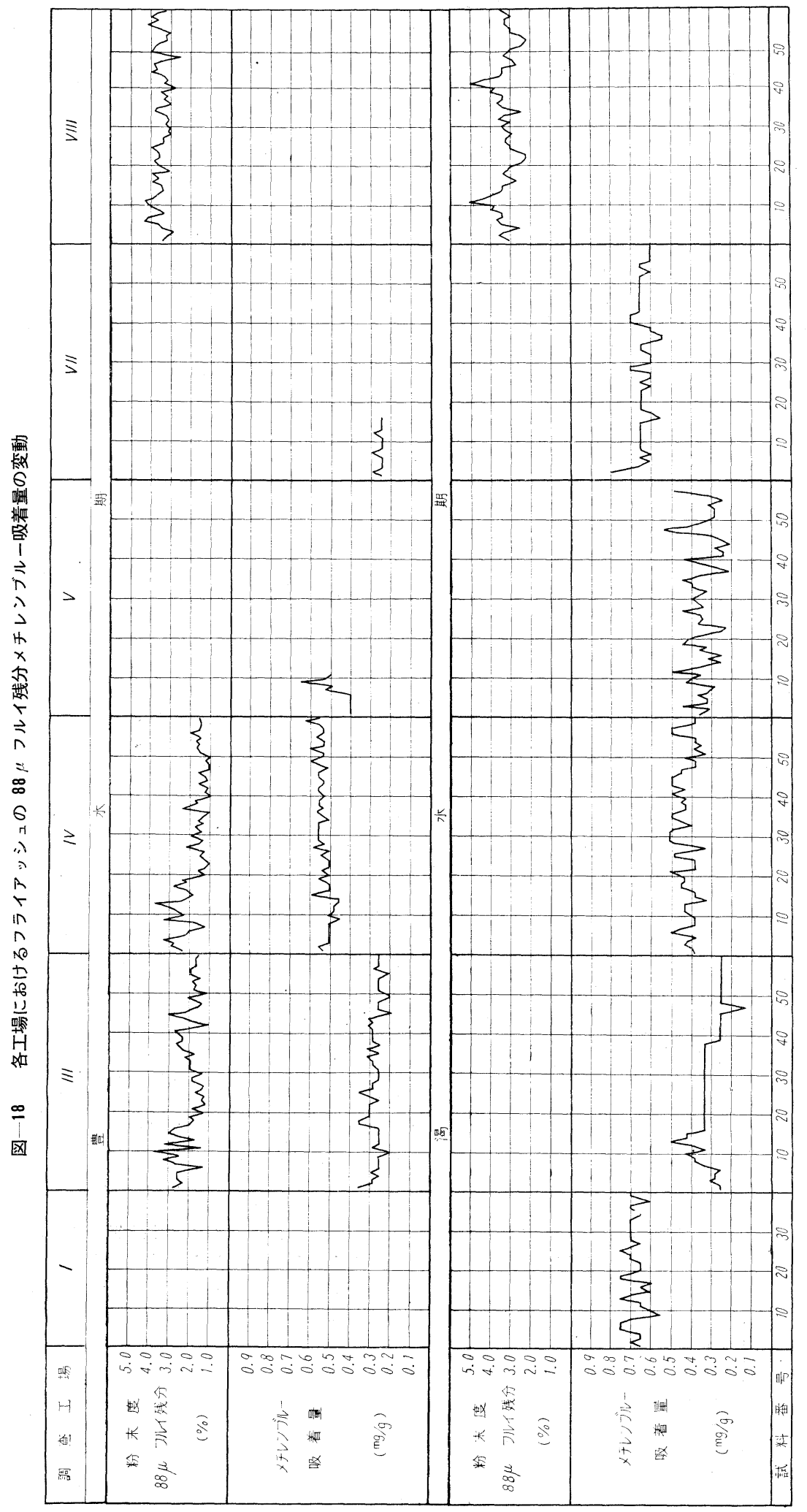


表一14 各工場におけるフライアッシュの品質の変動（その3）

\begin{tabular}{|c|c|c|c|c|c|c|c|c|c|c|c|c|c|c|c|c|c|}
\hline & & \multirow[b]{2}{*}{ 項 } & \multirow[b]{2}{*}{ 目 } & \multicolumn{3}{|c|}{ 醞 } & 水 & \multicolumn{3}{|c|}{ 期 } & \multicolumn{3}{|c|}{ 渴 } & \multicolumn{2}{|l|}{ 水 } & \multicolumn{2}{|l|}{ 期 } \\
\hline & & & & $\begin{array}{l}\text { 調查試 } \\
\text { 工料数 } \\
(n)\end{array}$ & $\begin{array}{c}\text { 平均値 } \\
(\bar{X})\end{array}$ & $\left|\begin{array}{c}\text { 標準偏差 } \\
(\sigma)\end{array}\right|$ & $\begin{array}{l}\text { 変動 } \\
\text { 係数 } \\
(V)\end{array}$ & $\begin{array}{c}\text { 最大值 } \\
\left(X_{\max }\right)\end{array}$ & \begin{tabular}{|c} 
最小值 \\
$\left(X_{\min }\right)$
\end{tabular} & \begin{tabular}{|c|} 
最大值 \\
- 最小值 \\
$(\boldsymbol{R})$
\end{tabular} & $\begin{array}{l}\text { 調查試料 } \\
\text { 工場数 } \\
(n)\end{array}$ & $\begin{array}{c}\text { 平均值 } \\
(\bar{X})\end{array}$ & $\begin{array}{c}\text { 標沽偏差 } \\
(\sigma)\end{array}$ & $\begin{array}{l}\text { 変動 } \\
\text { 係数 } \\
(V)\end{array}$ & $\left|\begin{array}{c}\text { 最大値 } \\
\left(X_{\max }\right)\end{array}\right|$ & $\begin{array}{c}\text { 最小值 } \\
\left(X_{1 \text { nin }}\right)\end{array}$ & 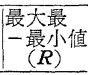 \\
\hline
\end{tabular}

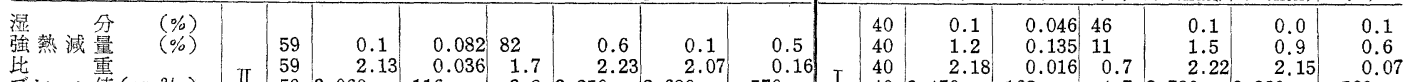

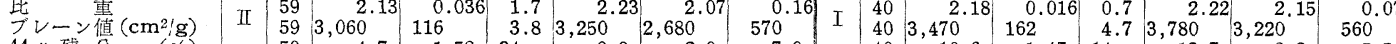

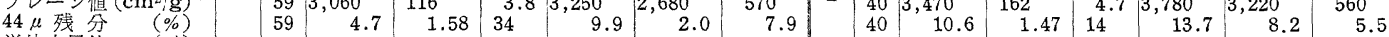

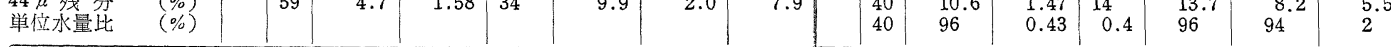

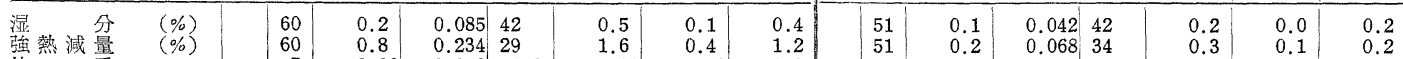

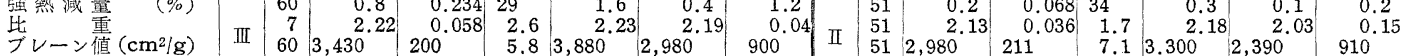

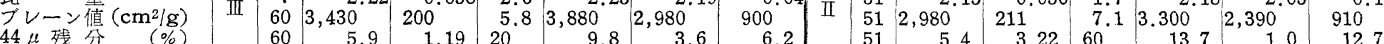

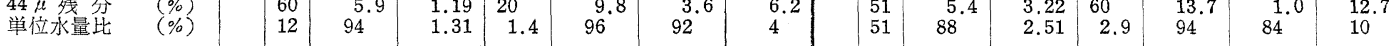

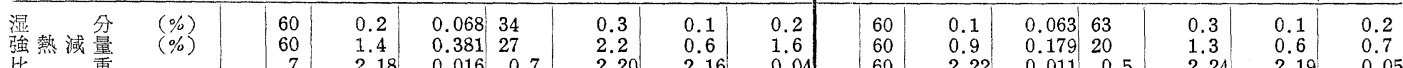

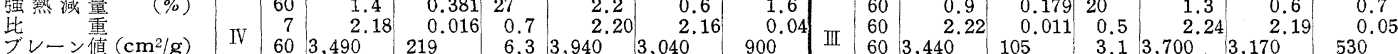

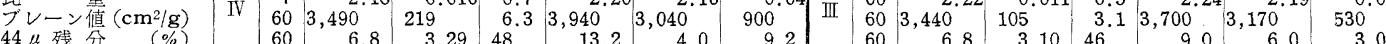

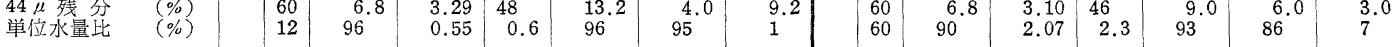

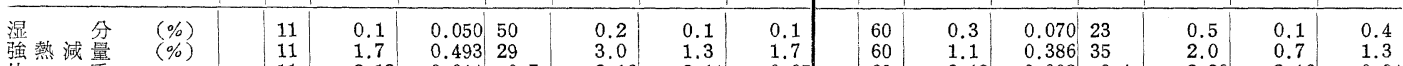

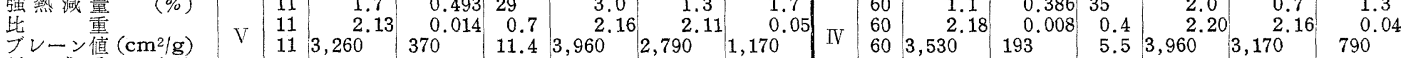

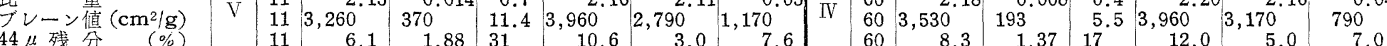

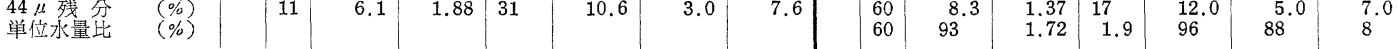

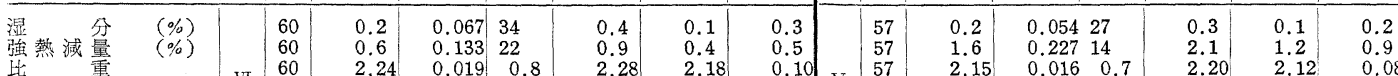

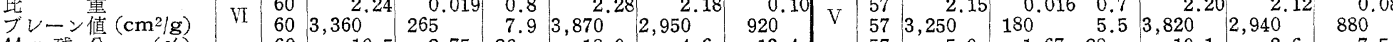

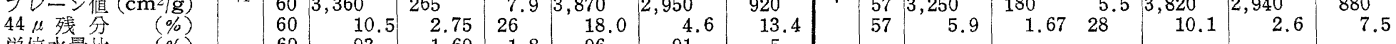

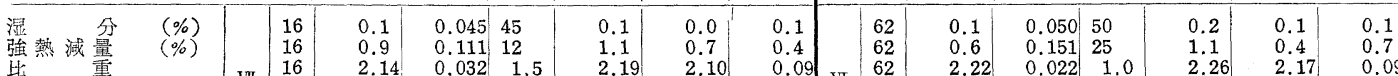

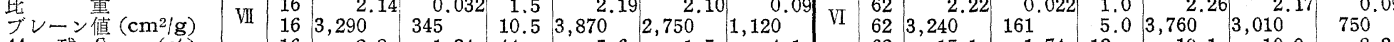

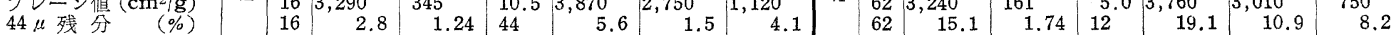

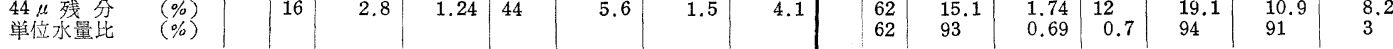

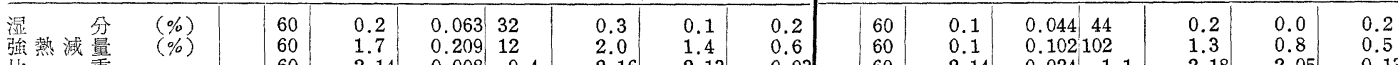

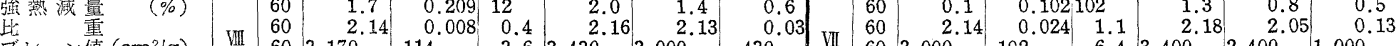

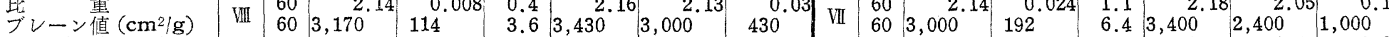

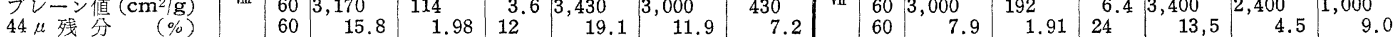

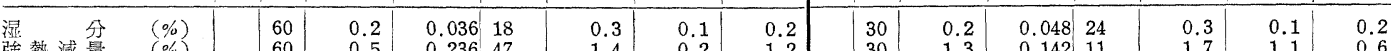

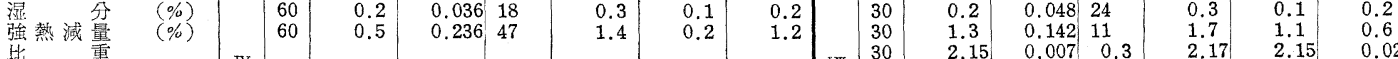

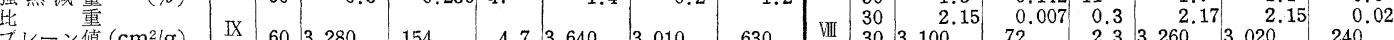
\begin{tabular}{ll|l|l|l|l|l|l|l|l|l|l|l|l|l|l|l|} 
ブレーン值 $\left(\mathrm{cm}^{2} / \mathrm{g}\right)$ & $\mathrm{IX}$ & 60 & 3,280 & 154 & 4.7 & 3,640 & 3,010 & 630 & 30 & 3,100 & 72 & 2.3 & 3,260 & 3,020 & 240
\end{tabular}

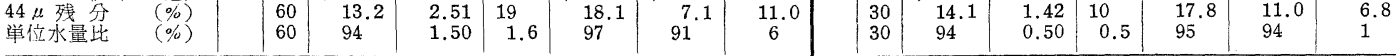

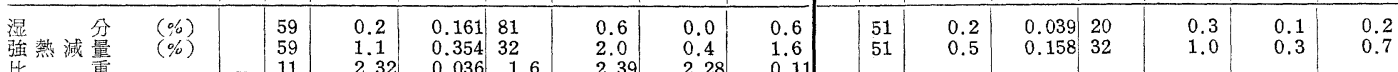

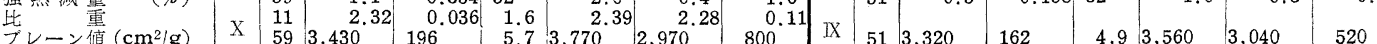

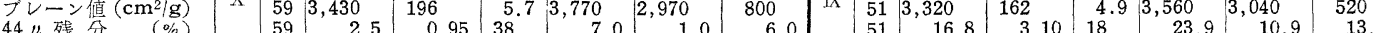
\begin{tabular}{ll|l|l|l|l|l|l|l|l|l|l|l|l|l|l|l|l|l}
$44 \mu$ 残分 & $(\%)$ & 59 & 2.5 & 0.95 & 38 & 7.0 & 1.0 & 6.0 & 51 & 16.8 & 3.10 & 18 & 23.9 & 10.9 & 13.0 \\
単位水量此 & $(\%)$ & 59 & 94 & 0.47 & 0.5 & 95 & 94 & 1 & & 51 & 93 & 1.64 & 1.8 & 96 & 90 & 6
\end{tabular}

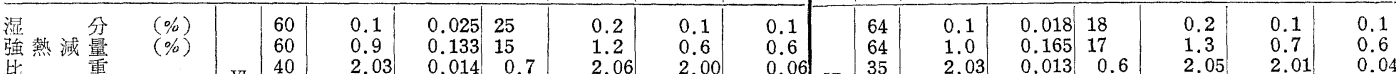

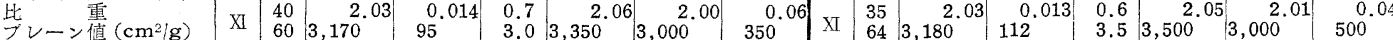

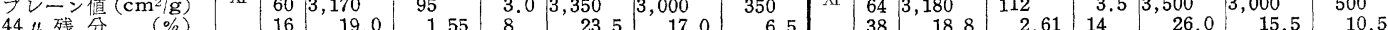

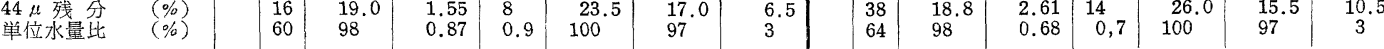

表一15 各工場におけるフライアッシュの $88 \mu$ フルイ残分とメチレンブルー吸着量の変動

\begin{tabular}{|c|c|c|c|c|c|c|c|c|}
\hline 調 查 & 工 & 場 & $I$ & III & IV & V & VII & VIII \\
\hline & & & \multicolumn{3}{|c|}{ 䇺 } & \multicolumn{3}{|c|}{ 期 } \\
\hline \begin{tabular}{c} 
粉 \\
$88 \mu$ フルイ 残 \\
\multicolumn{3}{c}{$(\%)$}
\end{tabular} & $\begin{array}{l}\text { 度 } \\
\text { 分 }\end{array}$ & $\begin{array}{l}n \\
\vec{X} \\
\sigma \\
V \\
X_{\max } \\
X_{\min } \\
R\end{array}$ & & $\begin{array}{c}60 \\
1.9 \\
0.60 \\
32 \\
3.6 \\
0.9 \\
2.7\end{array}$ & $\begin{array}{c}60 \\
1.7 \\
0.63 \\
37 \\
3.6 \\
0.9 \\
2.7\end{array}$ & & & $\begin{array}{c}60 \\
3.5 \\
0.37 \\
11 \\
4.3 \\
2.5 \\
1.8\end{array}$ \\
\hline $\begin{array}{c}\text { メチレンブル } \\
\text { 吸 着 } \\
(\mathrm{mg} / \mathrm{g})\end{array}$ & - & $\begin{array}{l}n \\
\bar{X} \\
\sigma \\
V \\
X_{\max } \\
X_{\min } \\
R\end{array}$ & & $\begin{array}{c}60 \\
0.27 \\
0.035 \\
13 \\
0.35 \\
0.18 \\
0.17\end{array}$ & $\begin{array}{l}60 \\
0.53 \\
0.033 \\
6 \\
0.60 \\
0.45 \\
0.15\end{array}$ & $\begin{array}{c}11 \\
* \quad 0.46 \\
0.079 \\
17 \\
0.64 \\
0.40 \\
0.24\end{array}$ & $\begin{array}{ll} & 16 \\
* & 0.25 \\
0.014 & \\
6 \\
0.28 \\
0.24 \\
0.04\end{array}$ & \\
\hline
\end{tabular}




\begin{tabular}{|c|c|c|c|c|c|c|c|c|}
\hline 調查 & 工 & 場 & $I$ & III & IV & V & $\mathrm{VI}$ & VII \\
\hline & & & \multicolumn{3}{|c|}{ 渴 } & \multicolumn{3}{|c|}{ 期 } \\
\hline \begin{tabular}{c} 
粉 \\
$88 \mu$ フル1 残 \\
\multicolumn{3}{c}{$(\%)$}
\end{tabular} & $\begin{array}{l}\text { 度 } \\
\text { 分 }\end{array}$ & $\begin{array}{l}n \\
\bar{X} \\
\sigma \\
V \\
X_{\max } \\
X_{\min } \\
R\end{array}$ & & & & & & $\begin{array}{l}60 \\
3.2 \\
0.57 \\
18 \\
5.0 \\
2.2 \\
2.8\end{array}$ \\
\hline $\begin{array}{c}\text { メチレンブル } \\
\text { 吸 } \begin{array}{c}\text { 着 } \\
(\mathrm{mg} / \mathrm{g})\end{array}\end{array}$ & 一 & $\begin{array}{l}n \bar{X} \\
\sigma \\
V \\
X_{\max } \\
X_{\min } \\
R\end{array}$ & $\begin{array}{l}40 \\
0.68 \\
0.049 \\
7 \\
0.75 \\
0.55 \\
0.20\end{array}$ & $\begin{array}{c}60 \\
0.30 \\
0.058 \\
19 \\
0.50 \\
0.13 \\
0.37\end{array}$ & $\begin{array}{c}60 \\
0.43 \\
0.052 \\
12 \\
0.52 \\
0.33 \\
0.17\end{array}$ & $\begin{array}{c}57 \\
* 0.34 \\
0.079 \\
23 \\
0.50 \\
0.20 \\
0.32\end{array}$ & $\begin{array}{l}60 \\
0.64 \\
0.044 \\
7 \\
0.80 \\
0.55 \\
0.25\end{array}$ & \\
\hline
\end{tabular}

注：*卵はメチレンブルーの代りにローダンを用いた試験值である

\section{第 6 章 結}

論

全国の 9 会社 13 工場で生産されるフライアッシュについて, 3 回にわたる品質試験を行い, また, 8 会社の 11工場飞招いてフライアッシュの品質の変動を豊水期招よび渴水期飞調查した結果, 調査研究の範囲内で次のこ とがい光ると思われる。

（1）合計 33 種のうち，32 種のフライアッシュが JIS A 6201～1958 の品質の規定飞合格している。また， これらのフライアッシュをコンクリートス用いて, 試験した結果も良好なるのであつた。すなわち, セメントの $25 \%$ をフライアッシュで招き換光て造つたコンクリートの材令 3 カ月以後の強度は, $21^{\circ} \mathrm{C}$ 水中養生の場 合に は，汪とんどすべてのフライアッシュに招いて，フライアッシュを用いないコンクリートの強度 $95 \%$ の以上と なつたのである。

しかし，フライアッシュの品質を相互、比較すればいちじるしい相違が認められること，ある工場では渴水期 と豊水期とでフライアッシュの品質飞大差が認められたこと，また，フライアッシュがコンクリートの諸性質に 呿よぼす影響はセメントの品質，フライアッシュの招き換え率，養生中の湿度括よび温度によつていちじるしく 相違すること，等を考慮すれば, フライアッシュの使用飞当つては十分な試験を行うことがぜひ必要である。

（2）JIS A 6201 亿規定するモルタルで試験した単位水量比招よび圧縮強度比の試験值は，そのフライアッ シュを用いたコンクリートの単位水量比抽よび圧縮強度比を推定するためのめやすになる。しかしフライアッ シュによるセメントの拓き換え率を同じくして比較しても，コンクリートの場合には，モルタルの場合よりる， 単位水量比は小さくなり圧縮強度比は大きくなる。また JIS の圧縮強度比飞不合格となつたフライアッシュで も，これをコンクリートに用いた場合の圧縮強度比では悪くない結果が得られた例がある。

従つてフライアッシュの品質は, JIS そよる試験值とコンクリートについての試験結果とから推定することが 大切である。

（3）主要な工場に和けるフライアッシュの品質の変動は, 渴水期にも豊水期にも, JIS A 6201 の品質の均 一性の規定の範囲内のるのであつた。すなわち各工場とる，生産されるフライアッシュのうち，規格に合格する 部分だけを商品として取披つていることが明らかにされた。品質が変動する程度は工場招よび時期によつて相当 飞相違しているから，重要な工事に用いるフライアッシュの場合には，品質管理の方法について入念飞研究する 必要がある。

な抒，JIS では品質の均一性をブレーン值と単位水量比とで規定しているが，これらの規格值については一首 の研究が必要であると思われる。

（4）フライアッシュを $\mathrm{AE} コ$ フリリートに用いる場合には，上后ど良質のフライアッシュでない限り，炭素 含有量, 粉末度, 等の変動によつて空気量が変化しコンクリートの管理が困難となる捛それがあるのであつて, 共通試験の一種の試料と抢いてすらこの変動が認められたととがある。

この変動による困難を解決するための実用的な方法を工夫することが重要である。これを要する，国内のフラ イアッシュについて調査研究を行い, 品質ならびに品質の均一性を明らか机することができたのであつて, 共通 試験の一応の目的は達成された。しかし，フライアッシュの品質ならびにその均一性は工場設備の影響を受ける ことがいらじるしいのであるから, 諸設備が急速に進歩しつつある現状を考ると, 数年後に再びこの種の共通試 験を行い，向上の程度を確かめてみたいと希望する次第である。 


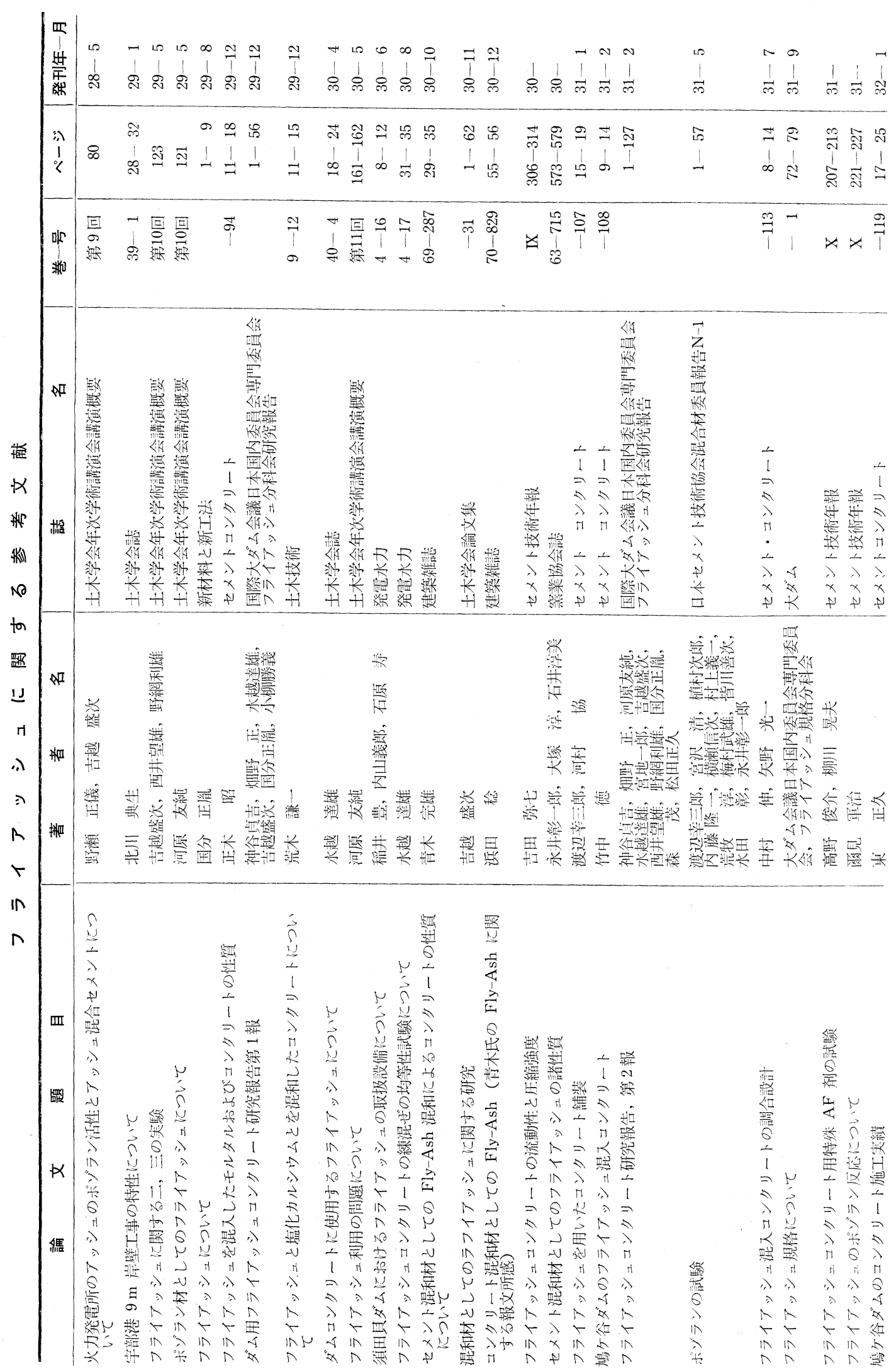




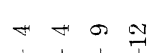
ง $\infty$

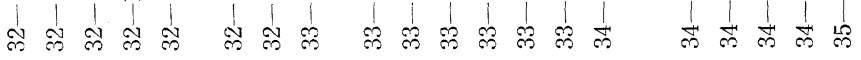

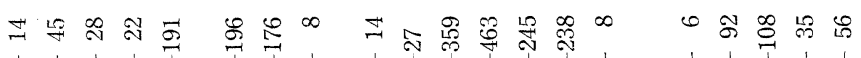

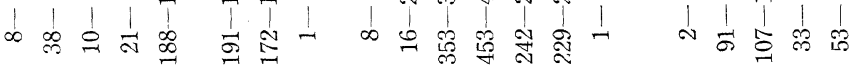
勇
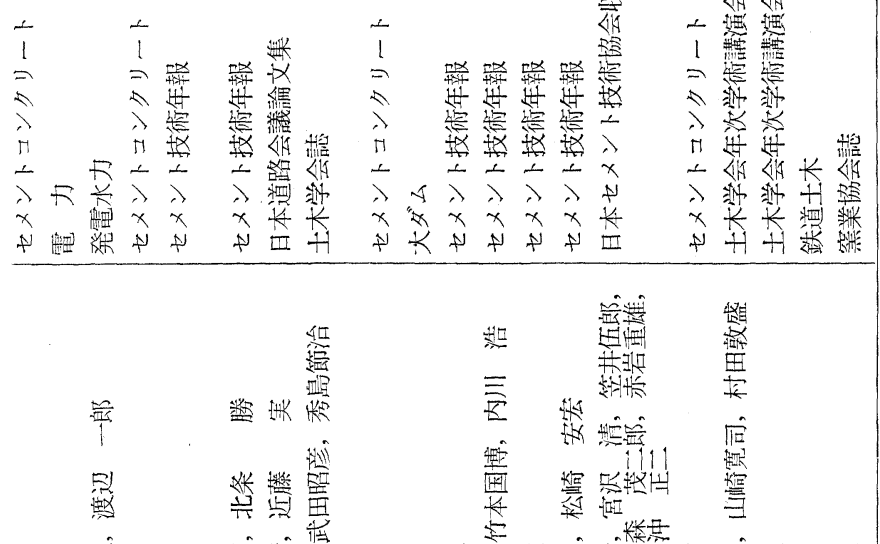

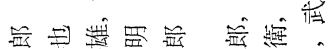

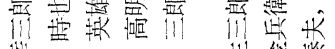

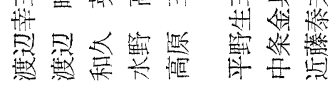
吅㞋11

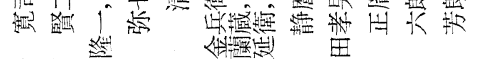

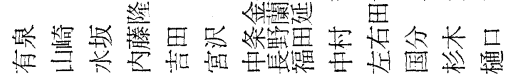

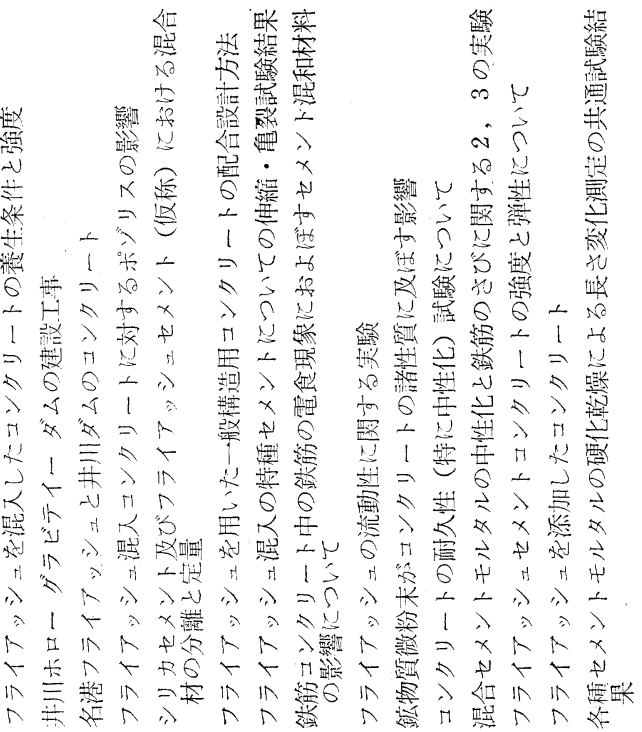

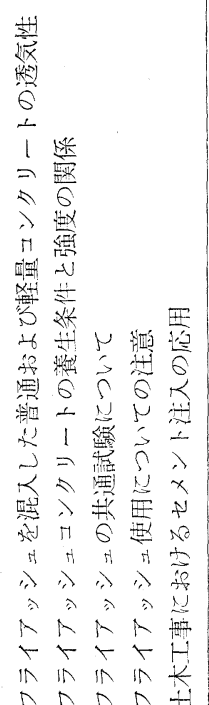




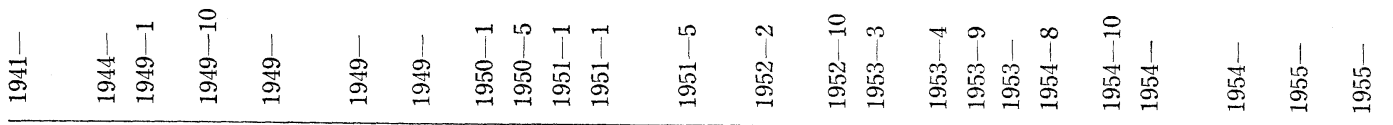

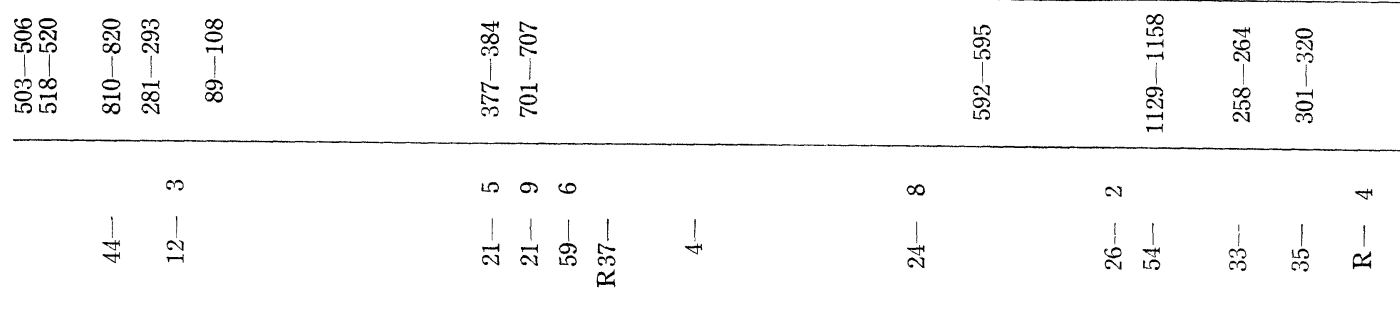

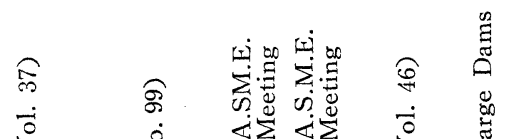

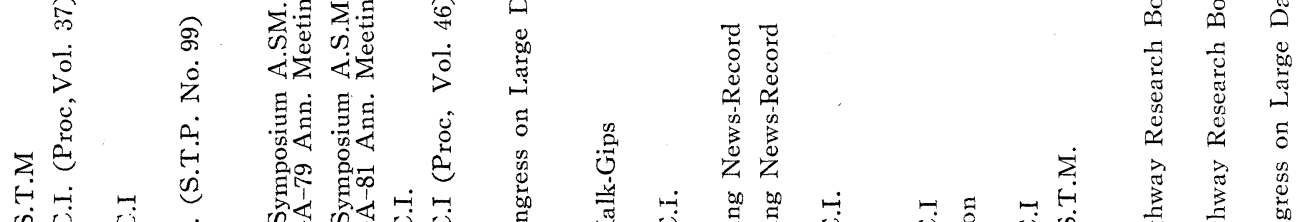

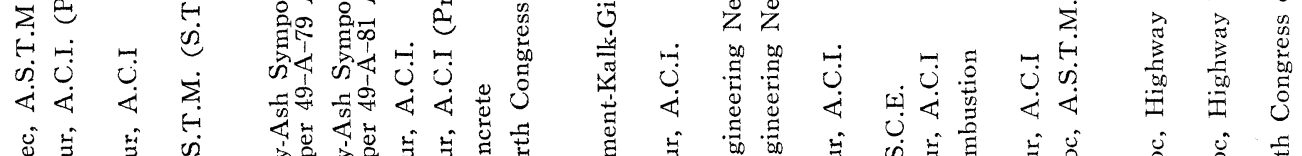

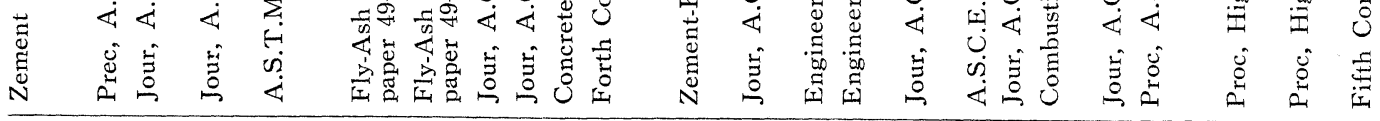

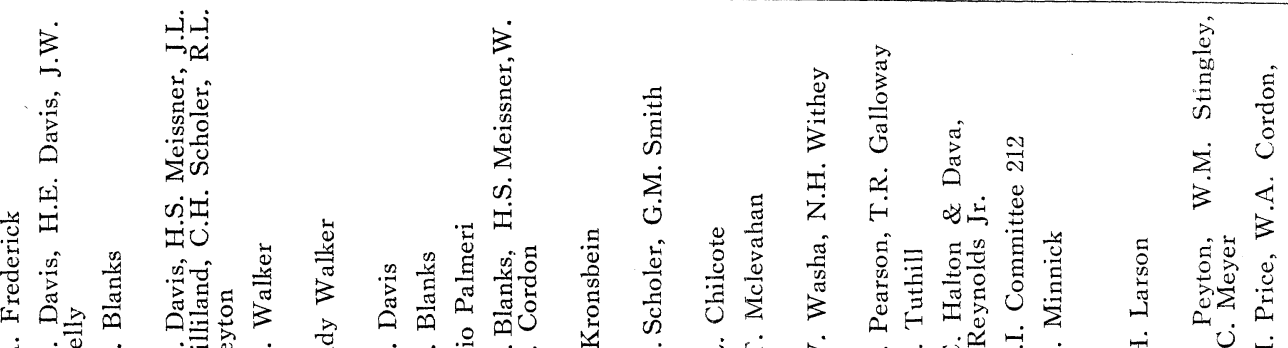

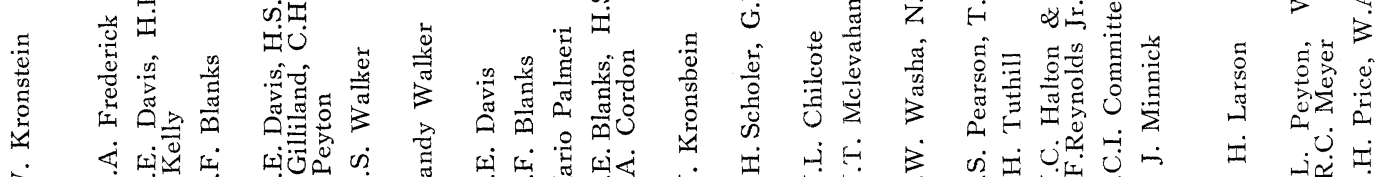
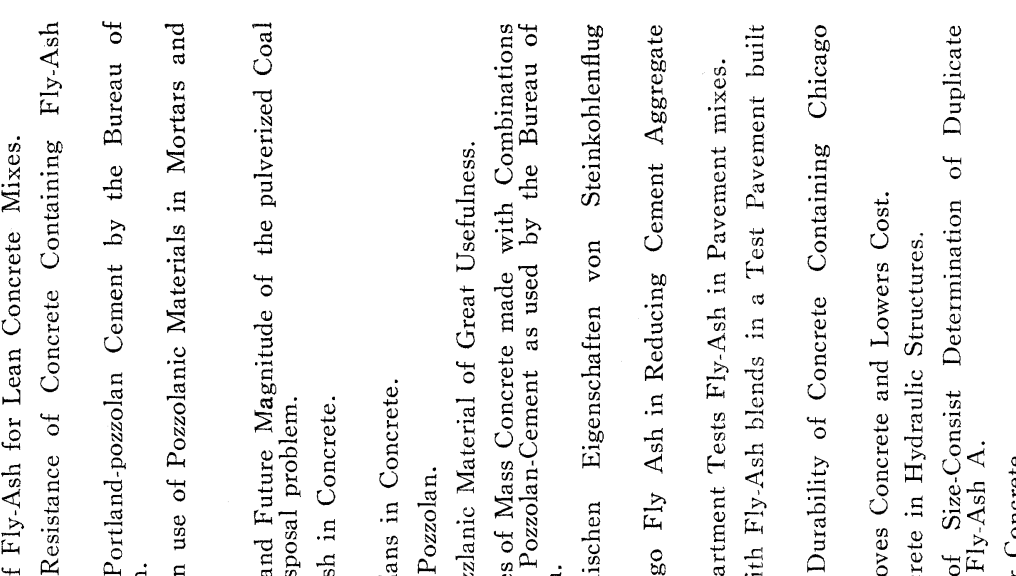

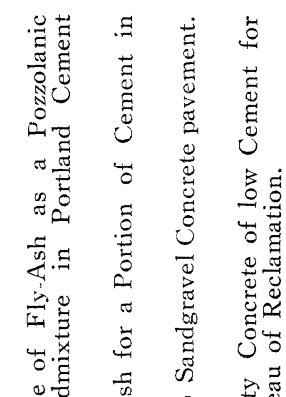

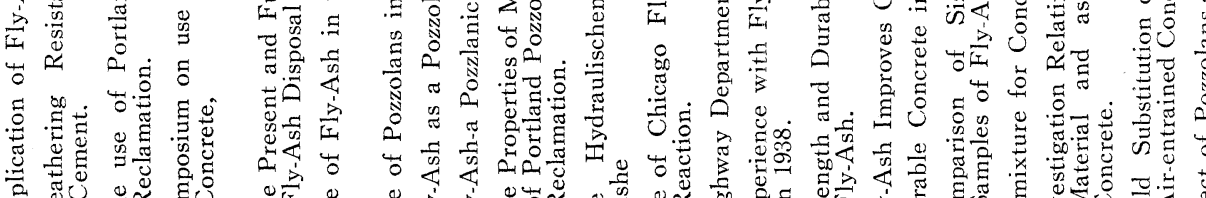

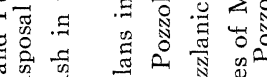

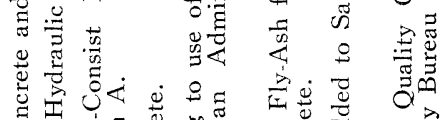

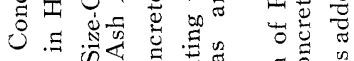




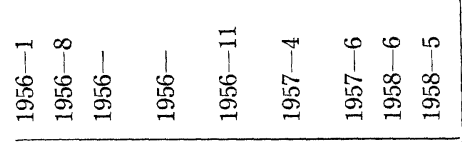

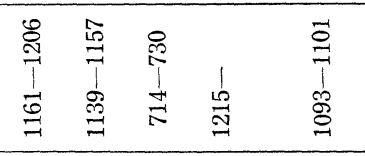

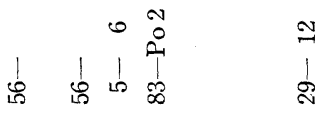

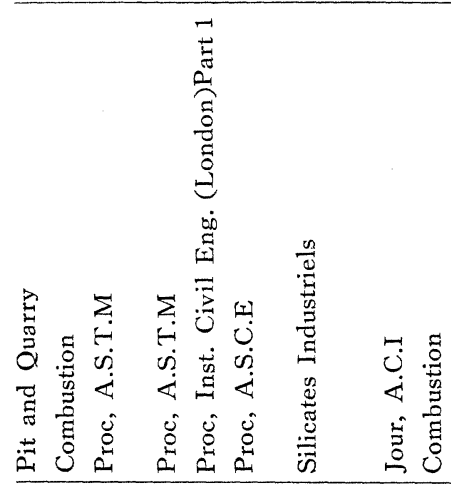

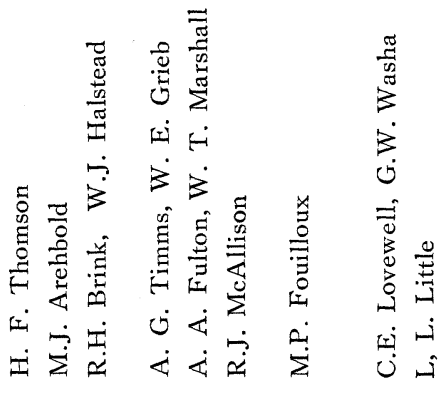

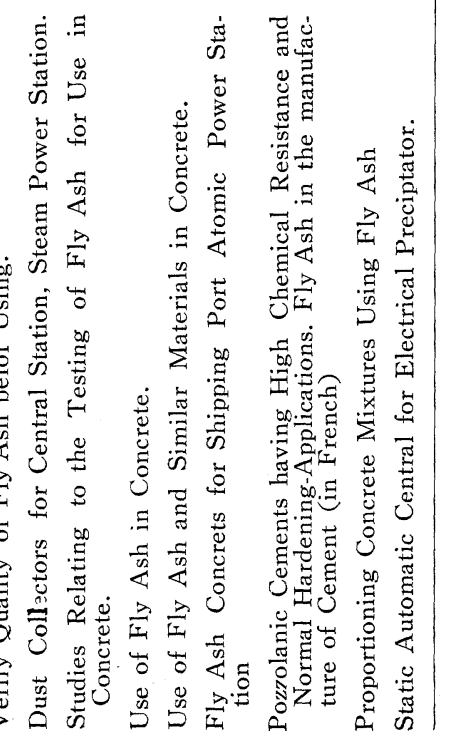

